BNL -31222

BNL 31222 ,

DE82 013799

\author{
The Synthesis of Carbon-11, Fluorine-18, and \\ Nitrogen-13 Labeled Radiotracers for Biomedical \\ Applications
}

by

Joanna S. Fowler

and

Alfred P. Wolf

Department of Chemistry

Brookhaven National Laboratory

Upton, New York 11973

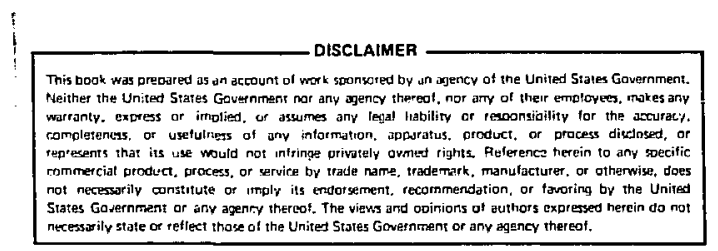

This research was carried out at Brookhaven National Laboratory under contract with the U. S. Departient of Energy anci supported by its Office of Basic Energy Sclesces and the Office of Health and Environmental Research.

\section{$\therefore$ NOTICE}

PORTIOTS OF THIS REPOPT ARE ILLEGIBLE.

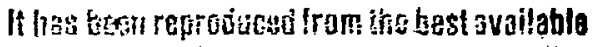
copy to permit the bracdest possible availability.
DISTRIGHTIOH OF THIS ROCUHENT IS UNLUMITE

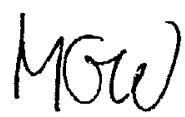


PREFACE

Many of the constraints within which the synthetic organic chemist must operate when designing and implementing a synthetic strategy for a short-lived radiotracer, do not exist or are unfmportant in the broader discipline of synthetic organic chemistry. However, the reactions used, the principles used to adapt these reactions to labeling with short-lived radionuclides, and the concepts of chemical reactivity are all part of the field of organic chemistry and form the framevork upon which synthetic strategies for short-1ived radiotracers are developed.

A number of reviews, many of them recent, have appeared on various aspects of ${ }^{11} \mathrm{C},{ }^{18} \mathrm{~F}$ and ${ }^{13} \mathrm{~N}$-labeled radiotracers. This monograph is intended to treat the topic principally from the standpoint of synthetic organic chemistry wile keeping in perspective the necessity of integrating the organic chemistry with the design and ultimate application of the radidtacer. Where possible, recent examples irom the literature of organic synthesis w11l be introduced to suggest potentially new routes which may be applied to problems in labeling organtc molecules with the short-lived positron eitters, carion-11, fluorine-18, and nitrogen-13.

The Table of Contents provides an overview of the material covered in this monograph. We reel that the literature survey of carbon-11, fluorine-18 and nitrogen-i3 labeled compounds (Tables 2,3,4,5 and 6) will be of particular value to scientists working in this field. Since the preparation of such a compilation is subject to unintentional omission and errors, we would be grateful if any onissions in this compilation of short-lived radiotracers be brought to out attention. Two appendices are included to provide supplementary general references. A subject index concludes this volume.

The authors are grateful to Alan Gelbard, Roy Tilbury, Kenneth Krohn, Ronald Finn and Michael Welch for providing preprints of their work. We also thank Michael welch, Karen McElvaney and Dominick Comar for providing material for illustration and Adrienne Farrell for preparing a number of the figures. We are particularly grateful to David Christman for preparing the section on radioactivity assay, to Karin Karlstrom and Robert MacGegor for organizational efforts associated with preparing this manuscript, and to Nancy Sautkulis, Lois Caligiuri and Michele Henderson for their patience, expertise art long nours spent in typing this manuscript. 
I. INTRODUCTION

Decay Charasteristics of the $\beta^{+}$Enftters $\ldots \ldots \ldots \ldots \ldots \ldots \ldots$

Table 1. Properties of ${ }^{14} \mathrm{C},{ }^{3} \mathrm{H},{ }^{11_{\mathrm{C}}},{ }^{18_{\mathrm{F}}},{ }^{13_{\mathrm{N}}} \ldots \ldots \ldots \ldots \ldots 2$

II. RADIOTRACER DESIGN 3

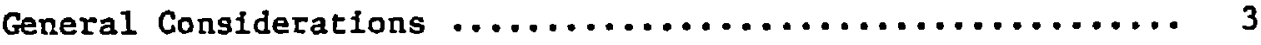

Cholce and Position of Label ....................... 4

$\begin{array}{ll}\text { III. RADIOTRACER SYNTHESIS } & 7\end{array}$

Avallability of Labeled Precursors ................. 7

Table 2. Labeled Precursors of ${ }^{11} \mathrm{C}, 18_{\mathrm{F}}$ and $13_{\mathrm{N}} \ldots \ldots \ldots \ldots$.

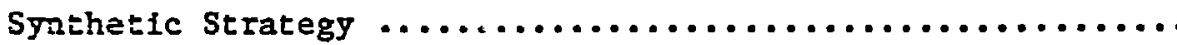

Table 3. Carbon-11 Iabeled Compounds ................ 11

Table 4. Fluorine-18 Labeled Compounds ............... 17

Table 5. 13/

Table 6. 13/-Labeled Compounds by Direct Chemical Synthesis 23

The Spnthetic strategy $\ldots \ldots \ldots \ldots \ldots \ldots \ldots \ldots \ldots \ldots \ldots \ldots \ldots . \ldots \ldots$

Optimization of Reaction Rates ..................... 24

Substzate Structure, Reducing Agents, Protective Groups and Solvents .................................... 25

Speci三ic Activity and Stoichiometry ................. 28

Expression of Yields and Specific Activity with Short-Lived Nuclides ....................................... 31

Biosyathetic Tactics .......................... 31

Radiotracer Purification and Quality Control ............. 34

IV. CARBON 11

Carbon-11 as a Label for Radtotracers ................. 38

Simple Carbon-11 Compounds and Other Precursors Used as Radiotzacers ................................ 39

Syathesis With Carbon-11 Labeled Precursors ............. 42

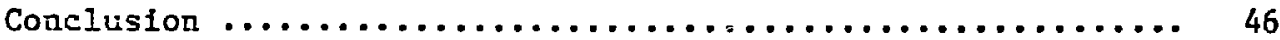

$\begin{array}{ll}\text { V. FLUORINE-18 } & 48\end{array}$

Fliforine-18 As A Label for Radiotracers ............... 48

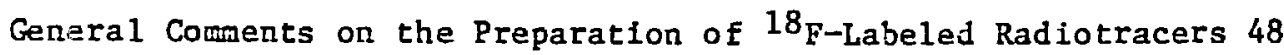
$18_{\text {F-Labeled Aryl Fluorides } \ldots \ldots \ldots \ldots \ldots \ldots \ldots \ldots \ldots \ldots} 49$

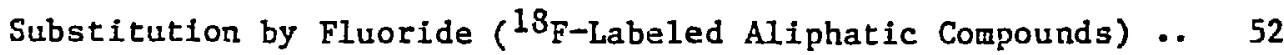

Table 7. Some Examples of Substitution by Fluoride (Inactive) 55 
V. FLUORINE-18 (continued)

Electrophilic Fluorination as a Route to ${ }^{18} \mathrm{~F}$-Labeled Compounds 56

Table 8. Some Examples of Electrophilic Fluorination Reactions 59

Statistical Factors and Radiochemical Yield ............. 60

Spectal Problems with 18F-Labeled Precursor Production and

Radiotracer Development .......................... 60

$\begin{array}{ll}\text { VI. NITROGEN-13 } & 62\end{array}$

VII. ERPERIMENTAL DESIGN AND RELATED TECHNOLOGY 65

Radioactivity Assay ......................... 65

Ion Chamber and Well Counter Calibration .............. 65

Zadioactivity Monitoring During a Synthesis ........... 67

Sintelded work Areas .......................... 69

3outine Production of Radfotracers for Clinical Studies ..... 70

Experimental Design Examples .................... 70

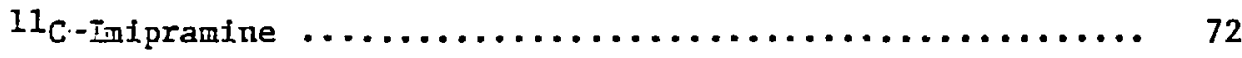

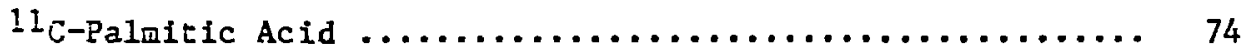

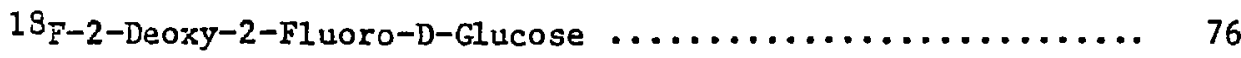

VIII. SLPPTEMEMTAL INFORMATION

Appendix 1. A Guide to the Literature of Organic Synthesis - 78

Appendix 2. A Guide to the Literature on Organic Synthesis with Isotopes - Especially Positron Emitters ....... 82

IX. BIBITOGRAPYY

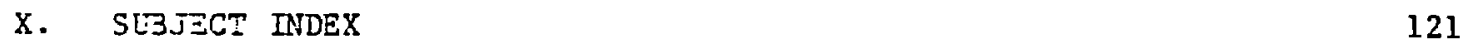


TNTRODUCT ION

The successful application of organic molecules labeled with the short-lived positron emitting nuclides to the study of physlological processes In the living human body has generated intense interest in the biomedical community (1-6). For example, it has recently been possible to correlate regional brain metabolism with functional activity in humans during normal circumstances (7-9), under conditions of somatosensory stimulation (10-13) and in psychiatric conditions (14-17) through the use of positron emitting radiotracers. This characterization of the metabolic activity of the functioning human brain and other organs such as the heart (18) depends on the use of positron emission transaxial tomography (PETT) a method of detection which gives an image of the distribution of the labeled tracer in a transverse section of the body (4,19-22). Th1s mode of detection makes it posstble to Image the internal structure of an organ without interference from overlying structures. Thus by applying the approprlate labeled tracers, mathematical models (3) and instrumentation to problems in the blomedical sciences it has been possible for the first time to obtain regional metabolic information in the living humen body at little or no risk. This has resulted in the birth of a new Interdisciplinary endeavor.

The monograph wll deal with the problems encountered in one of the key areas on which the success of these studies depends, namely, the various aspects of labeling organic molecules with the short-lived nuclides carbon-II, fluorine-18 and nitrogen-13. This is an area in which synthetic organic chemistry plays a key role. Before considering the development of synthetic

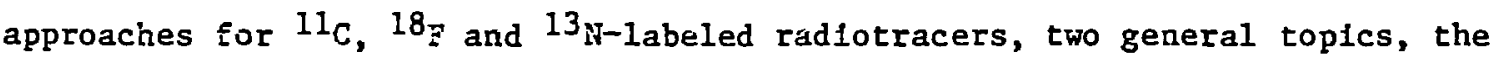
decay characteristics of the positron emitters and radiotracer design will be discussed.

Decay Characteristics of the Positron Enitters ( $\left.{ }^{1 I_{C}},{ }^{18} \mathrm{~F},{ }^{13} \mathrm{~N}\right)$

The use of tracer molecules to study the blochemical processes occurring In living organisms relies heavily on carbon-14 and tritlum labels since these nuclides can be substituted for stable carbon and hydrogen in organic molecules without changing the blological properties of the molecule. An immense amount of information has been obtained through the use of carbon-14 and tritiun labeled tracers even though their long half-lives and short-range decay characteristics largely preclude their use in humans. However, studies involving carbon-14 and tritium labeled tracers can provide guidance on both the design and synthesis of positron emitting tracers. 
By comparison, the nuclides carbon-11, nitrogen-13 and, to a great extent, fluorine-18 can also be used to label organic molecules without apprectably altering their blological properties. These nuclides which are produced by a cyclotron or other charged particle accelerator decay by positron emission resulting in the production of two $511 \mathrm{KeV}$ photons which, unlike carbon-14 and tritium, can be detected external to the body barrier. The short half-life and body penetrating radiation makes molecules labeled with the positron emitting nuclides sultable for safely tracing metabolic processes in the living human body. Furthermore, the much higher speciflc activities attainable with the short-lived nuclides makes it possible to use them as labels for toxic molecules where the resulting tracers show no measurable physlological effects. Indeed organic molecules labeled with the positron enitters have provided the means of extending many of the elegant tracer methods developed with carbon-14 and tritium to studies in humans $(7,23)$. The physical properties of tritlum, carbon-14, carbon-11, nitrogen-13 and fluorine-18 aze sumarlzed in Table 1.

Table 1. Physical Properties of Tritium, Carbon-14, Carbon-11, Nitrogen-13 and Fluorine-18

\begin{tabular}{|c|c|c|c|c|c|c|c|}
\hline Nuclide & HalE-life & $\begin{array}{l}\text { Decay } \\
\text { Mode }\end{array}$ & $\begin{array}{l}\text { Maximum } \\
\text { Energy } \\
\text { (MeV) }\end{array}$ & $\begin{array}{c}\text { Most } \\
\text { Probable } \\
\text { Energy } \\
\text { (MeV) }\end{array}$ & $\begin{array}{c}\text { Range }^{a} \\
\left(\mathrm{H}_{2} \mathrm{O}\right)\end{array}$ & $\mathrm{m}^{-1}$ & $\begin{array}{l}\text { Maximum } \\
\text { Specific } \\
\text { Activity } \\
\text { (CI/mol) }\end{array}$ \\
\hline $\begin{array}{l}\text { Tritium } \\
\text { Carbon-14 } \\
\text { Carbon-11 } \\
\text { Nitrogen-13 } \\
\text { Fluorine-18 }\end{array}$ & $\begin{array}{c}12.35 \mathrm{y} \\
5730 \mathrm{y} \\
20.4 \mathrm{~m} \\
9.96 \mathrm{~m} \\
109.7 \mathrm{~m}\end{array}$ & $\begin{array}{l}s^{-}(100 \%) \\
s^{-}(100 \%) \\
s^{+}(99+\%) \\
s^{+}(100 \%) \\
\beta^{+}(97 \%) \\
\text { EC }(3 \%)\end{array}$ & $\begin{array}{l}0.0185 \\
0.155 \\
0.96 \\
1.19 \\
0.635\end{array}$ & $\begin{array}{l}-- \\
\overline{0.326} \\
0.432 \\
0.202\end{array}$ & $\begin{array}{l}0.0072 \\
0.359 \\
4.108 \\
5.39 \\
2.39\end{array}$ & $\begin{array}{l}1.07 \times 10^{-7} \\
2.30 \times 10^{-10} \\
3.40 \times 10^{-2} \\
6.96 \times 10^{-2} \\
6.32 \times 10^{-3}\end{array}$ & $\begin{array}{l}2.90 \times 10^{4} \\
62.4 \\
9.22 \times 10^{9} \\
1.89 \times 10^{10} \\
1.71 \times 10^{9}\end{array}$ \\
\hline
\end{tabular}

a Maximua.

On examination of the physical properties of the positron emitters the following three properties, in addition to their ready substitution for the natural elements of orgenic molecules, make them exquisitely suitable as tracers which cat be used in humans:

(1) Short half-iffe

(2) Dacay by body penetrating radiation

(3) Potentially high specific activity

These three properties are also responsible for the unique problems which must be overcome in the development of a practical syrthetic route to a tracer molecule labeled with the carbon-11, fluorine-18 or nitrogen-13. 
RADIOTRACER DESIGN

General Considerations

The expenditure of time and resources In developing a synthetic route to a short-1ived radiotracer is usually sufficiently great to warrant a careful cholce of the molecular structure 1tself. The process of choosing a molecular structure for probing a particular physiological process thereby setting priorities for synthesis is referred to as radiotracer design. It involves the consideration of many aspects of the interaction of chemicals with living systems and can include the consideration of such factors as tissue blochemistry, molecular requirements for substrate transport into a tissue, intracellular $\mathrm{pR}$, and unique functions, to name a few. In this phase of the development of a new radiotracer, a familiarity with the literature as well as the Input of both physiclans and other sclentists with expertise in the biological sciences is necessary. Since pharmaceutical research and radiopharmaceutical research share some comon problems and goals (24), the Itterature of this field is a valuable resource and should also be used in selecting priorities for synthesis.

The design of organ imaging radiopharmaceuticals has been reviewed (25-27). More zecently, radiotracers have been classified according to their mechanism of concentration in the target organ $(28,29)$. This mechanistic approach to radiotracer design is receiving increasing attention (30). Along this line, the determination of structure-activity relationships, which allow one to correlate and predict the biodistribution patterns of molecules in the body based on chemical structure, provides an extremely valuable foundation for the develcpment of new radiotracers (31-34).

In the application of radiotracers and emission tomography to the study of biological processes in humans, the following two realities define the biodistribution characteristics which the labeled tracer must exhibit.

(1) For reasons of radiation safety and minimizing human radiation dose, the amount of radioactivity which can be injected has an upper limit.

(2) The detection of the radioactivity which is injected is limited by the sensitivity of the avallable instrumentation.

While the instrumentation continues to laprove, the first factor, namely the amount of radiotracer which can be safely administered is limited. Therefore, the design of tracers which have a high uptake in the organ of interest is critically important because the higher the uptake in the area of interest, the lower will be the dose of the radioactivity required to provide a statistically significant count rate for imaging. In this regard, one must 
consider not only whether the tracer has a desired interaction with a particular functional component of the organ which is being studied (for example, a neurotransmitter receptor, an enzyme or a carrier protein) but also whether its behavior in the whole body and its transport into the tissue of interest favors a sufficlent uptake for study.

Since the literature can provide considerable information on the relationship of chemical structure to uptake of substances in tissues or cellular components the following selected references are provided as a guide:

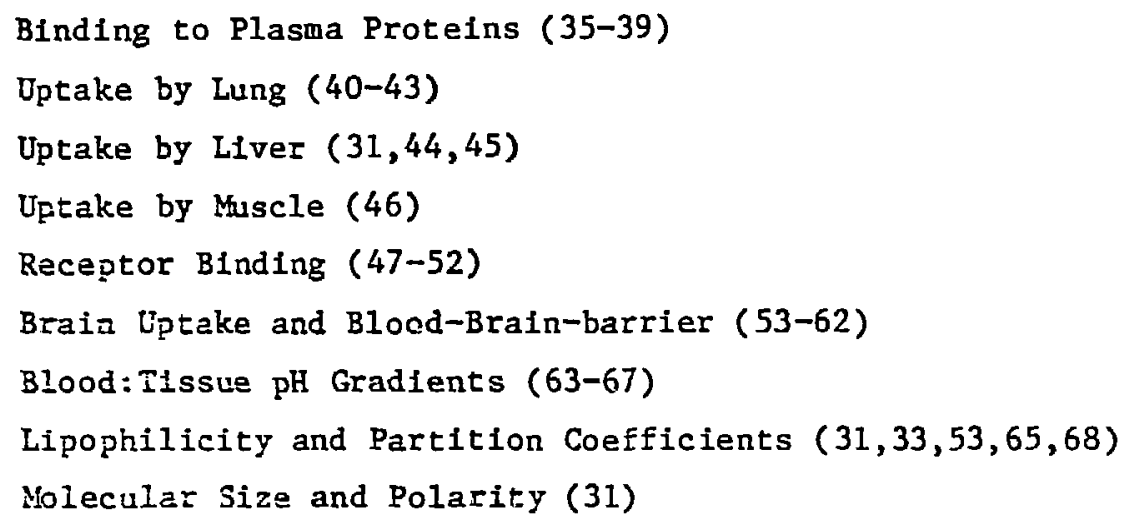

The site specific delivery or targeting of radiotracers which probe particular espects of the metabolism and function of a target organ or tissue is a particuierly challenging aspect of radiotracer development. It has been approached in a numer of ways including the use of enzyme inhibitors (69-70), receptor-Iigant interactions (47-48,50-52,71), metabolic trapping (72-73), and liposome formation (67,74-76). Another tactic, frequently used in Fharmaceutical research is to form "prodrugs" to aid the site-specific delivery of pareat molecules (77-78). Prodrugs are derlvatives of the parent molecule and aze designed to release the active molecule in vivo. This approach nay also prove to be useful in radiotracer design.

At this point, it is important to emphasize the value of determining localization ectianisms for radlotracers which have high organ specificities. This information, along with various studies on the relationship of chemical structure to biodistribution patterns, is a valuable resource for developing new radiotracers.

\section{Cholce and Position of the Label}

After the choice of a chemical structure for a given biomedical application has been made, then the cholce and position of the radioactive nuclide within the tracer molecule becomes a consideration. The time course of the biological process which is befing traced is a factor which influences 
the choice of nuclide since the half-life, ldeally, should be sufficlently long to obtain the desired uniform but not so long as to contribute unnecessarliy to the body radiation burden. In some cases, studies of the dynamics of distribution of a tracer in animals using tritium or carbon-14 as Jabels can provide information on the time scale of the biological process and therefore serve as a guide in the cholce of positron enitting nuclides.

The position as well as the choice of the label often is sictated by the structure of the molecule and the limited number of routes possible for introducing the radionuclide. In many cases, however, there are alternatives which must be considered. In the case of isotopic substitution there will be no perceptible alteration in the biological behavior of the molecule in most cases. However, if a foreign radloelement (for example, fluorine-18) is used to label the molecule, then the choice for the position of the label must be made so that the resulting radiotracer maintains the desired characteristics of the parent molecule. For example, the design of a positron emitting tracer which could be used to extend the ${ }^{14} \mathrm{C}-2$-deoxyglucose method (23) to humans using PETT required the consideration of a number of factors and lead to the cholce of $18_{\vec{F}}$-labeled 2-deoxy-2-fluoro-D-glucose (FDG) as a molecular structure. Fluorine-18 was initially the nuclide of choice because the relativeiy iong ( 110 minute) half life was required for the transport of the tracer from Brookhaven National Laboratory where it was synthesized to the University of Pennsyivania where the first imaging studies were done. In addition, the half-life of fluorine-18, is compatible with the time required

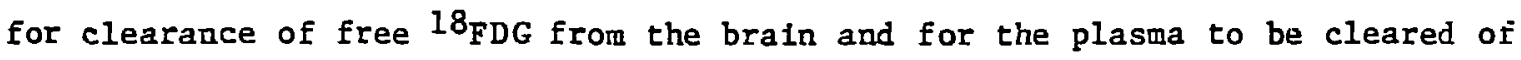
tracer thus minimizing errors in quantitation. The cholce of position 2 for the fluorine-18 label was made because it was well known that this is the inly position which could be altered without seriously reducing the ability of this molecule to serve as a substrate for hexokinase anc that the absence of a hydroxyl grotip at $\mathrm{C}-2$ is essential for metabolic trapping (79-81). (Figure 1)

Another factor which must be considered whether the labeling involves isotopic substitution or the use of a forelgn radfoelement is the metabolism of the wolecule. It is important that the label be sufficiently stable in vivo to provide the information required fiom a particular study. Along this line, the choice of the position of the label may be judiciously made to influence its excretion rate and lower the radiation dosimetry. 


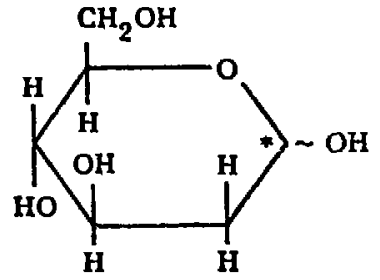

$1-{ }^{14} \mathrm{C}-2$ - DEOXY-D-GLUCOSE

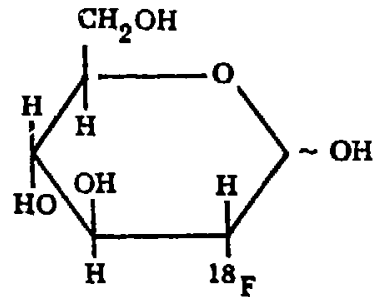

${ }^{18}$ F-2-DEOXY-2-FLUORO-D-GLUCOSE
RADIOTRACER REQUIREMENTS

1. Radiotracer must be a substrate for hexokinase (.: only $\mathrm{C}_{\boldsymbol{2}}$ can be modified).

2. Radiotracer must undergo carrier mediated transport into the brain ( $\therefore$ only $\mathrm{C}_{2}$ can be modified).

3. Radiotracer must be metabolically trapped ( $\therefore \mathrm{C}_{2}$ hydroxyl must be absent).

4. Nuclide $t / 2$ must be compatible with free tracer clearance and shipping time.

Figura 1. Radlotracer requirements for extenc? Ing the ${ }^{14} \mathrm{C}-2-$ deoxy-D-glucose method to humans using PETT. 


\section{RY.OTOTRACER SYNTHESIS}

After the vartous factors which impact on the design of a particular radiotracer have been considered and a molecular structure which appears to satisfy the requirements of a particular biomedical application bas been chosen, the primary challenge is the design of an approprlate synthetic approach to this radiotracer. In general, the synthetic strategy must be compatible with the following conditions:

1. The radioactivity must be introduced in the fs=m sf a rsadily accessible labeled precursor molecule which is obtained directly from the target or is readily synthestaed from the molecular spectes produced in $r . \ldots$ target. In some cases the synthesis may necessitate the development of a new route to the labeled precursor.

2. The reaction steps including and subsequert to the introduction of radioactivity must be sufficiently rapid to be compatible with the half life of the nuclide. This also applies to purification procedures which are required in the synthesis.

3. The synthetic sequence must be chosen with a consideration of the mechinlsui of the reaction and of the specific activity of the product which is required. This will impact on the stoichlometry of varlous steps of the synthesis.

4. When the syathesis involving high levels of radioactivity is carried out on a routine or semi-routine basis, techaical aspects of the experimental setup such as the design of the laboratory shielding, remote operations, elimination of non-essential manfpulations, and radiation monitoring require attention.

On this basis, the general topics of availability of labeled precursors, the synthetic strategy, optimization of reaction rates, specific activity and stolchiometry, blosynthetic tactics and rapld purification will be discussed followed by sections devoted to the synthesis of carbon-11, fluorine-18 and nitrogen-13 lajeled tracers. A section on experimental methods and related technology

\section{Avallability of Labeled Precursors}

The factor which has the greatest impact on development of a practical synthetic strategy is the avallability of the radioisotope and labeled precursor molecules. The nuclear reaction which is used and the yleld of tuclide which can be obtained from a farticular reaction is highly dependent 
on cyclotron/accelerator characteristics. The chemical form of the nuclide whirh is produced after bombardment is determined by a number of factors, the most important being energy deposition in the target and chenical composition of the target. Because of the Importance of precursor avallability to the synthetf.c strategy the reader is referred to $a$ number of articles on this topic $(1,82-86)$ as well as the references in Table 2. In addition, consultation with individuals who have experience with targetry, precursor preparation and delivery systems is recomended.

The ideal radiotracer synthesis is one which the nuclide is introduced from a labeled precursor molecule which is avallable directly from the target or where the species available from the target is directly converted without handling (i-e. "on line") to a syrithetically useful precursor. In addition, the Incorporation of the radionuclide should proceed in high yleld with a minimum number of steps and time being required after the introduction of the label thus minimizing the hazards of handling large quantities of radfoactivity. Table 2 provides a list of commonly used precursor forms of ${ }^{11} \mathrm{C},{ }^{18} \mathrm{~F}$ and $13 \mathrm{~N}$. Those which are avallable directly from the target or "on-1Ine" are, of course, the most attractive in terms of the simplicity of the overall syzthetic strategy. Others involve conversion of the labelled species exising the target to a useful chemical form as is indicated in the table. Although a large number of precursor molecules are listed, some have been used to a far greater extent than others as can be seen by examining the listings of ${ }^{11} \mathrm{C}, 18_{\mathrm{F}}$ and ${ }^{13} \mathrm{~N}$ labeled compounds (Tables $3,4,5,6$ ). The development of sew labeled precursors or the improvement and simplification of existing gethods, Including automation is an important area of research since it greatly increases the diversity of the structures of labeled radiotracers which can be syzthesized. 
Table 2. Labeled Precursors of ${ }^{11} \mathrm{C}, 18_{\mathrm{F}}$ and ${ }^{13} \mathrm{~N}$

Carbon-11 Labeled Precursors

References

Direct or On-Line Avallability

${ }^{11} \mathrm{CO}$

$87-89$

${ }^{2} \mathrm{I}_{\mathrm{CO}}$

$88-89$

$\mathrm{H}^{11} \mathrm{CN}$

$89-92$

products from solid $\mathrm{NH}_{4} \mathrm{Cl}$ target

( ${ }^{11}$-organlc halides, methylamine,

formamide, cyanamide, guanldine)

93

${ }^{11}$ C-guantdine

94-95

${ }^{11} \mathrm{CH}_{3} \mathrm{I}$

96

Synthesis Required

${ }^{1} 1_{\mathrm{CH}_{3} \mathrm{I}}$

97-99

$\mathrm{H}^{11_{\mathrm{CHO}}}$

98, 100-101

${ }^{11} \mathrm{CH}_{3} \mathrm{LI}$

102

$\left.{ }^{11} \mathrm{C}\right]$ cyanate

103

${ }^{11 \mathrm{COCl}_{2}}$

104-109

$\mathrm{H}^{11} \mathrm{CCH}$

110-115

Fluorine-18 Labelad Precursors

Direct or On-Iine Availability

$\mathrm{H}^{18} \mathrm{~F}$ (aquenus)

$116-120$

$\mathrm{H}^{18} \mathrm{~F}$ (anhydrous)

121-129

${ }^{18} \mathrm{~F} \cdot \mathrm{F}_{2}$

$125,130-132$

$\mathrm{B}^{18} \mathrm{~F}_{3}$ (aniydrous)

133-134

$M^{18} F$ (arhydzous) where $M=R_{4} N^{+}, \mathrm{Cs}^{+}, \mathrm{K}^{+}$and other cations

or fon exchange resin. (See Table 4 for examples)

135

$\mathrm{Ne} / 18_{\mathrm{F}}$ (species not identified)

$0_{2} / 18_{F}$ (species not identified)

$120,133,136$

No ${ }^{18}$ F

137

$\mathrm{Cl}^{18_{\mathrm{F}}}$

118,125

$\mathrm{ClO}_{3}{ }^{18_{F}}$

125

$\mathrm{CH}_{3} \mathrm{CO}_{2}{ }^{18_{F}}$

138

139

Synthesis Regrired

$\mathrm{A}^{18} \mathrm{~F}$ (anhydrous) from $\mathrm{H}_{2} \mathrm{O}$ target

(See Table 4)

$\mathrm{H}^{18} \mathrm{~F}$ (anhydrous) from $\mathrm{KHF}_{2}$ target

140

$\mathrm{M}^{18} \mathrm{~F}$ (aniydrous) fron $\mathrm{H}_{2} \mathrm{O}$ target

$\left[{ }^{18} \mathrm{~F}_{\mathrm{CF}_{3}}\right.$ OF

(See Table 4)

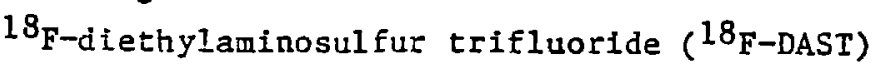

141-142

${ }^{18} \mathrm{~F} \mathrm{XeF}_{2}$

128

$143-144$ 
Table 2. Labeled Precursors of ${ }^{11} \mathrm{C},{ }^{18} \mathrm{~F}$ and ${ }^{13} \mathrm{~N}$ (continuation).

N1trogen-13 Labeled Precursors

Direct or On-Line Availability

$13 \mathrm{NO}_{3}-$

$145-149$

$13 \mathrm{NH}_{3}$

150-152

Synthesis Required

$13 \mathrm{NB}_{3}$ (from $\mathrm{H}_{2} \mathrm{O}$ target)

$146,149,153-157$

$\mathrm{H}^{13} \mathrm{NO}_{2},{ }^{13} \mathrm{NO}_{2}^{-},{ }^{13} \mathrm{NO}^{13}{ }^{13} \mathrm{NO}_{2}$

$149,158-161$

$13 \mathrm{~N}_{2} \mathrm{O}$

113,162

$13_{\mathrm{N}_{2}}$

$113,149,163$

General References (see Appendix 2)

Carbon-11: $\quad 86,164,170$

Fluorire-18: $132,165-157,170$

N1trogen-13: 168-169 
Table 3. Carbon-11 Labeled Compounds.

Coupound

Labeled Labelling

Precursor Reagent

References

[ ${ }^{11_{C}}$ ]Amino AcIds

[carboxyl-11 $\mathrm{C}$ ] $\alpha$-phenylglycine

\begin{tabular}{|c|c|c|}
\hline${ }^{11} \mathrm{CO}_{2}$ & ${ }^{11} \mathrm{CO}_{2}$ & $171-174$ \\
\hline $\mathrm{H}^{11} \mathrm{CN}$ & $\mathrm{H}^{11_{\mathrm{CN}}}$ & 175 \\
\hline${ }^{11} \mathrm{CO}_{2}$ & ${ }^{11} \mathrm{CO}_{2}$ & $172-174$ \\
\hline $\mathrm{H}^{11_{C N}}$ & $\mathrm{H}^{11} \mathrm{CN}$ & 175 \\
\hline •• & $"$ & 176 \\
\hline$"$ & $"$ & 176 \\
\hline${ }^{11} \mathrm{CO}_{2}$ & ${ }^{11} \mathrm{CO}_{2}$ & 177 \\
\hline$"$ & $"$ & $115,178-179$ \\
\hline $\mathrm{H}^{1 I_{C N}}$ & $\mathrm{H}^{11} \mathrm{CN}$ & 180 \\
\hline${ }^{11} \mathrm{CO}_{2}$ & ${ }^{11} \mathrm{CO}_{2}$ & $181-182$ \\
\hline " & ${ }^{11_{\mathrm{CH}_{3}} \mathrm{I}}$ & 178 \\
\hline n & $"$ & 183 \\
\hline$"$ & $"$ & $97,184-186$ \\
\hline $\mathrm{H}^{11} \mathrm{CN}$ & $\mathrm{H}^{11} \mathrm{CN}$ & $172,187-188$ \\
\hline " & " & $175,189,191$ \\
\hline$"$ & $"$ & $175,190,192$ \\
\hline " & $"$ & $175,190,193$ \\
\hline none & none & 194 \\
\hline $\mathrm{A}^{11} \mathrm{CN}$ & $\mathrm{H}^{11} \mathrm{CN}$ & $175,190,194 a$ \\
\hline " & $"$ & 195 \\
\hline " & $"$ & $175,190,196-197$ \\
\hline •. & $"$ & 198 \\
\hline " & $"$ & 187 \\
\hline${ }^{11} \mathrm{CO}_{2}$ & ${ }^{11} \mathrm{CO}_{2}$ & $199-200$ \\
\hline $\mathrm{H}^{11_{\mathrm{CN}}}$ & $\mathrm{H}^{11} \mathrm{CN}$ & 187 \\
\hline$"$ & 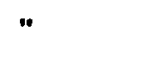 & 201 \\
\hline 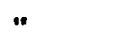 & $"$ & 202 \\
\hline
\end{tabular}

[carboxyl-11 $\mathrm{C}$ ] $\alpha$-phenylglycine

[carboxy1-11 $C$ ] $\alpha$-phenylalanine

[carboxy1- ${ }^{11_{C}}$ ]-a-phenylalanine

$D-\left[\right.$ carboxy $1-11_{C}$ ] phenylalanine*

$\mathrm{L}_{-}$-[carboxy $-^{-11} \mathrm{C}$ ] phenylalantne*

[carboxy1-11 $C$ ] DOPA

$D, L-\left[1-11_{C}\right]$ alanine

$D, L-\left[1-{ }^{11_{C}}\right]$ alanine

L-[1-11C]alanine*

[3-1 ${ }_{C}$ ]alanline (Fortlally resolved)

$D, L-\left[3-11_{C j a l a n i n e}\right.$

L-[methyl-11 C] methionine

$\beta-[3-11$ alanine

1-aminocyclopentane ${ }^{1 l_{C}}$ ]carboxylic acid

1-aminocyclobutane [ ${ }^{1} \mathrm{C}$ ]carborylic acid

1-aminocyclohexane $\left[{ }^{11_{C}}\right.$ ] carboxylic acid

D,L-valine (not labelef)

$D, L-[1-11 \mathrm{C}]$ valine

$L-\left[1-11_{C}\right]$ valine

D,L-[carboxyl-11C]tryptophan

L-[carboxyI-11 C] tryptophan

$D, L-\left[4-11_{C}\right]$ aspartic asid

L-[4-11C] aspartic acid*

$\mathrm{P}-\left[{ }^{11_{C}}\right]$ cyanophenylalanine

[11C]-L-glutamic actd

[ $\left.{ }^{11} \mathrm{C}\right]-L-c-a m i n a 1 s o b u t y r f c$ acid

[11C] Carboxylic Acids and Derivatives

$D, L-[1-11$ C $]$ lactic acid

${ }^{11} \mathrm{CO}_{2} \quad \mathrm{H}^{11_{\mathrm{CN}}} \quad 211$

$D, L-[1-11 \mathrm{C}]$ lactic acid

$\mathrm{H}^{11} \mathrm{CN}$

$\mathrm{H}^{11_{\mathrm{CN}}}$

203

D, L- $\left[1-{ }^{1}{ }^{1}\right]$ lactic acid

${ }^{11} \mathrm{CO}_{2}$

$\mathrm{H}^{11} \mathrm{CCH}$

111,204

$D, L-\left[3-1 l_{C}\right]$ lactic acid

"

111,204 
Table 3. Carbon-11 Labeled Compounds (continuation).

Compound

Labeled

Labelling References

Precursor Reagent

$L-[3-11$ C] lactic acid*

"

$\mathrm{L}-[1-11 \mathrm{C}]$ lactic acid*

[carbony] $-11 \mathrm{C}$ ] nicotinamide

[carboxy1-11 C] oIcotinic acid

[1-11 $\mathrm{C}$ palmitic acid

[i-11C]oleic acid

$\beta$-methyl $\left[1-{ }^{11} C\right]$ heptadecanoic acid

[11 C]acrylic acid

[11 c]citric acid*

[1-11 $\mathrm{C}]$ octanoic acid

[1-11 C]acetate

[1-11 C]propionic acid

[1-11 c]pyrüic actd*

[carboxpl-11 C]aliphatic cärboxylates ${ }^{a}$

[1-11 C]acetoace $=i c$ acid

[carboxyl-1ic] salicylic acid

[carboxil-11 C] anthranilic acid

[carboxy1-11 $c$ ] benzolc acid

[carbox $1-1 \frac{1}{b} \mathrm{c}$ ] ber Jic acid

[11C]hippuric acid*

[11 ${ }^{1}$ ] ace:yl phosphate*

${ }^{11}$ C] acetyl carnitine*

[carboxyl-il C] carboxylates ${ }^{c}$

[carboxyl-11 ${ }$ ] mandelic acid and esters

[14-11 $\mathrm{C}$ ] succinic actd

[14-11 C] funaric acid

${ }^{11}$ C-oxalacetate*
${ }^{11} \mathrm{CH}_{3} \mathrm{I} \quad 183$

${ }^{11} \mathrm{CO}_{2} \quad 181,182,205$

" 115,200

" $\quad 115,207$

*

$115,208-211$

212

213

214

215

41,216

216-218

219

$181-182,205$

216

220

115,216

115

$115,216,221$.

216

221

222

223

216

$\mathrm{H}^{11} \mathrm{CN} \quad \mathrm{H}^{11_{\mathrm{CN}}} \quad 224$

" 225

" $" 225$

${ }^{11} \mathrm{CO}_{2} \quad{ }^{11} \mathrm{CO}_{2} \quad 200,215$

$\mathrm{N}-\left[{ }^{1} 1_{C}\right]$ Methyl $3^{\circ}$ Amines and $\left[{ }^{11} \mathrm{C}\right]$ Yethy1-Quaternary Ammonium Salts Lethy1 Quaternary Akmonium Salts

[N-methyI-11C]morphine and heroin

[N-methy $1-{ }^{11} \mathrm{C}$ ]morphine

${ }^{11} \mathrm{CO}_{2} \quad{ }^{11} \mathrm{CH}_{3} \mathrm{I} \quad 226$

O-methyl $\left[{ }^{1} \mathrm{C}\right]$ bufotenine

"

$\mathrm{B}^{12} \mathrm{CHO}$

" 
Table 3. Carbon-11 Labeled Compounds (continuation).

\begin{tabular}{lcc}
\hline Compound & Labeled & Labelling References \\
& Precursor & Reagent
\end{tabular}

$\mathrm{N}-\left[{ }^{1} \mathrm{C}\right]$ methylputrescine, spermine and spermidine

[N-methy1-11 C] imipranine

[N-methyl-11 $\mathrm{C}$ ]clomipramine

[N-methyl-11 C]chlorpromazine

[N-methyl-11 $\mathrm{C}$ ] etorphine

[N-methyl-11 C]nicotine

[N-methyl-11 $\mathrm{C}$ ] thioproperazine

[ ${ }^{11} \mathrm{C}$ ] ephedrine

${ }^{11}{ }^{1}$ ]methylephedrine

$\mathrm{N}-\left[{ }^{11} \mathrm{C}\right]$ methyl albunin and fibrinogen

$\mathrm{N}-\left[{ }^{11} \mathrm{C}\right]$ metinyl ovfne lutenizing hormone

Gly-[11 ${ }^{1}$-metingI] Met-Gly

[N-methyl-11 C] diazepam

[N-methyl-11C]caífeine

[N-methy]-11 $\mathrm{C}$ j Ilunitrazepam

[N-methy1-II C jhexamethonium

[11c]-erythronycin A 1actoblonate

$1^{1} 1^{1}-\left[11^{1} \mathrm{C}\right]$ methy:-4 $4^{\prime}-$

chlorprozazine- $\left[{ }^{1 l_{C}}\right.$ ]methlodide

quinuclidingl benzllate $\left[{ }^{11} \mathrm{C}\right]$-methiodide

$\left[1-11_{C}\right]$ Pr1mary Amines and Derivatives

[1-11 C] dopazine $\cdot \mathrm{HC} 1$

[1-11 C] norepinephrine $\cdot \mathrm{HCl}$

$\left[1-1 C_{C}\right]$-hyzroxytryptamine $\cdot \mathrm{BC} 1$

$\left[1-1{ }^{11}\right.$ ]aliphatic amines $\left(\mathrm{C}_{4}-\mathrm{C}_{8}, \mathrm{C}_{10}\right)$

$\left[1-{ }^{1} \mathrm{l}_{\mathrm{C}}\right] \mathrm{b}$ rauch chain aliphatic amines

${ }^{11_{C}}$ ]aliphatic diamines $\left(\mathrm{C}_{4}-\mathrm{C}_{9}\right)$

$\left[1-11_{C}\right] d i a e$ thoxyphenethylamine

$[1-11 \mathrm{C}]$ phenethylamine
"

229

"

$185,230-231$

$"$

232-233

"

185,234

" 235

"

$185,231,236$

$23 !$

237

237

238

$\mathrm{H}^{11} \mathrm{CHO}$

239

${ }^{11} \mathrm{CH}_{3} \mathrm{I} \quad 240$

"

231,241

231,237

241,242

243,244

•

$\mathrm{H}^{11} \mathrm{CHO}$

$244 a$

${ }^{1} \mathrm{CH}_{3} \mathrm{I}$

245

“

246

"

247-249

$\begin{array}{lll}\mathrm{H}^{11_{\mathrm{CN}}} & \mathrm{H}^{11} \mathrm{CN} & 250-252 \\ \text { " } & \text { " } & 253 \\ \text { " } & \text { " } & 254 \\ \text { " } & \text { " } & 41,255 \\ \text { " } & \text { " } & 256 \\ \text { " } & \text { " } & 257 \\ \text { " } & \text { " } & 258 \\ & \text { " } & 259,260\end{array}$


Table 3. Carbon-11 Labeled Compounds (continuation).

Compound

Labeled Precursor
Labelling References Reagent
[1-11 $\mathrm{C}]-6$-iododopamine

$\left[{ }^{11} \mathrm{C}\right]-\mathrm{N}-\mathrm{a}$ lsy $]-\underline{\mathrm{p}}-$ Iodobenzenesulfonamides

[3-11 $C] 6,7-d$ ihydroxy-1, 2, 3, 4-

tetrahydroisoquinoline

[a-methylene- ${ }^{11_{C}}$ ]salsolinol

${ }^{11}$ C]Alcohols

[ ${ }^{11_{C}}$ ]methyl alcohol

$\left[1-11_{C}\right]$ ethyl alcohol

$\left[1-11_{C}\right]$ kexadecanol

[2-11C]2-propanol

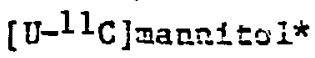

[u-11C]gigcerol*

[1-11 $\mathrm{C}$ ]octanol

$\left[{ }^{11} C\right]$ Sugars

$\left.[0-1]_{C}\right]$ gIucos $\mathrm{e}^{*}$

$\left[\mathrm{U}^{-11} \mathrm{C}\right] \mathrm{giucose*}$

${ }^{11}$ C-galactose*

$3-\left[{ }^{1 l_{C}}\right]$-aethyl-D-glucose

$\left[1-11_{C}\right]-2-j e o x y-D-g l u c o s e$

$[1-11 \mathrm{C}]-$ glucose

$\left[1-11_{C}\right]$-aanncse

[cyano-11C] M1triles

lacto ${ }^{1 I_{C}}$ ]nitrile

octane $\left[{ }^{1 l} \mathrm{C}\right] \mathrm{nItrile}$

2-phenylethylaminoalkane[ ${ }^{11} \mathrm{C}$ ]nitrile tici

mandelo $\left[{ }^{11} \mathrm{C}\right] \mathrm{nit}$ (1)

$a-p$-Iodoani11nophenylaceto $\left[{ }^{11} \mathrm{c}\right]$ nitrile

$\alpha-N-a l k y l a d i n o p h e n y l a c e t o\left[{ }^{11} C\right] n i t r i l e s$

$\alpha-\mathrm{N}$-aryladinophenylaceto [ ${ }^{1 l_{C}} \mathrm{C}$ attriles
"

261

"

262

,

252

252

$\begin{array}{lll}{ }^{11} \mathrm{CO}_{2} & { }^{11} \mathrm{CO}_{2} & 263 \\ " & " & 212,263-265 \\ " & n & 187 \\ " & " & 263 \\ " & . & 266 \\ . & " & 266 \\ & . & 41\end{array}$

$\begin{array}{lll}{ }^{11} \mathrm{CO}_{2} & { }^{11} \mathrm{CO}_{2} & 267-270 \\ " & \mathrm{~B}^{11} \mathrm{CO}_{3} & 271 \\ " & { }^{11} \mathrm{CO}_{2} & 266 \\ " & { }^{11} \mathrm{CH}_{3 \mathrm{I}} & 271 \mathrm{a}, 272 \\ \mathrm{H}^{11} \mathrm{CN} & \mathrm{H}^{11} \mathrm{CN} & 273-277 \\ " & " & 278 \\ . & " & 278\end{array}$

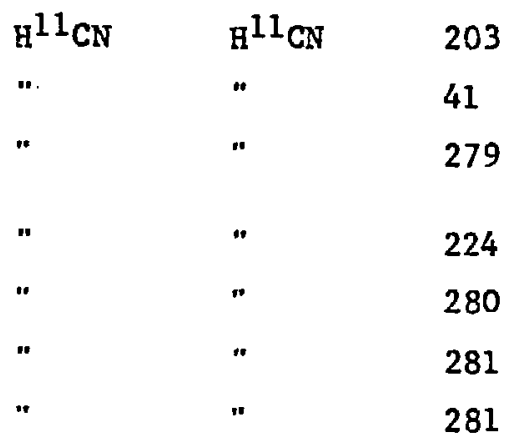


Table 3. Carbon-11 Labeled Compounds (continuation).

Labeled Labelling References
Precursor Reagent

[1 $\left.{ }^{1} \mathrm{C}\right]$ Hydantoins

[11C]dlalkylhydantoins

$\begin{array}{lll}\mathrm{H}^{11_{\mathrm{CN}}} & \mathrm{H}^{11_{\mathrm{CN}}} & \mathbf{2 8 2 - 2 8 3} \\ " & " & 105,282-287 \\ " & " & 283 \\ " & " & 282-283,286 \\ { }^{11_{\mathrm{CO}}} & { }^{11_{\mathrm{COC1}}} & 286\end{array}$

[11C]diary1hydantoins

[11 $\mathrm{C}$ ]spirohydantoins

${ }^{11} \mathrm{C}$ ]alkylarylhydantoins

${ }^{11}$ C]alkylarylhydantoins

Precursor Reagent

Steroids

$17-\alpha-\left[11_{C}\right]$ methylestradiol

$\begin{array}{lll}11 \mathrm{CO}_{2} & { }^{11} \mathrm{CH}_{3} \mathrm{Li} & 288-289 \\ . & " & 288,290 \\ . & . & 288 \\ . & \mathrm{H}^{11} \mathrm{CCH} & 112 \\ . & . & 289\end{array}$

Mitscellaneous ${ }^{11} \mathrm{C}$-Labeled Compounds

\begin{tabular}{|c|c|c|c|}
\hline$\left[1-11_{C}\right]$ octanal & $1 I_{\mathrm{CO}}$ & ${ }^{11} \mathrm{CO}$ & 291 \\
\hline [carbony1-11 $C$ ] benzaldehyde & 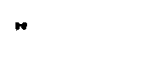 & " & $291-292$ \\
\hline [carbony1-11 C]pinozide & " & ${ }^{11} \mathrm{CoCl}_{2}$ & 293 \\
\hline$\left[{ }^{11}\right.$ C] ethylchloroformate & $"$ & $"$ & 105,109 \\
\hline$\left[{ }^{11} \mathrm{C}\right]$ diethyicarbonate & $"$ & $"$ & 105,109 \\
\hline [11 C]diphenyiurea & $"$ & $"$ & 105,109 \\
\hline$\left.{ }^{11} \mathrm{C}\right] 5,5$-diethylbarbiturate & $"$ & $"$ & 105,286 \\
\hline [ $\left.{ }^{11} \mathrm{C}\right] 5,5$-ethylphenylbarbiturate & $"$ & $"$ & 105,286 \\
\hline$\left[1-11_{C}\right]$ hexobarbital & ${ }^{11} \mathrm{CO}_{2}$ & ${ }^{\mathrm{I}} \mathrm{CH}_{3} \mathrm{I}$ & $294-295$ \\
\hline$\left[{ }^{11_{C}}\right.$ ]hydroxpurea/1sohydroxyurea & $\mathrm{B}^{11} \mathrm{CN}$ & ${ }^{11}$ C-cyanate & 103 \\
\hline$\left[{ }^{1 I_{C}}\right]$ urea & ${ }^{11} \mathrm{CO}$ & ${ }^{11_{\mathrm{COCl}_{2}}}$ & 296 \\
\hline Benzyl- $\left[{ }^{1} \mathrm{C}\right]$ wethyl ether & ${ }^{11} \mathrm{CO}_{2}$ & ${ }^{11} \mathrm{CO}_{2}$ & 297 \\
\hline [methylene- ${ }^{-1}{ }_{C}$ ] benzyl methyl ether & " & $"$ & 297 \\
\hline ButyI[ $\left.{ }^{11} \mathrm{C}\right]$ methyl ether & $"$ & $"$ & 297 \\
\hline$\left[{ }^{1 l_{C}}\right.$-aethylene]dlethyl ether & " & 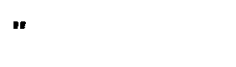 & 297 \\
\hline $\begin{array}{l}{ }^{11} \text { C-labeled aliphatic and aromatic } \\
\text { hydrocarbons }\end{array}$ & $"$ & ${ }^{1} 1_{\mathrm{CH}_{3} \mathrm{I}}$ & 298 \\
\hline$\left[{ }^{11} \mathrm{C}\right.$ ]benzene, toluene, xylene & $\mathrm{u}^{11} \mathrm{CCH}$ & $\mathrm{H}^{\mathrm{Il}} \mathrm{CCH}$ & 299 \\
\hline$\left[2-11_{C}\right]$-acetone & ${ }^{11} \mathrm{CO}_{2}$ & $1 \mathrm{~L}_{\mathrm{CO}_{2}}$ & 300 \\
\hline
\end{tabular}


Table 3. Carbon-11 Labeled Compounds (continuation).

\begin{tabular}{|c|c|c|c|}
\hline Compound & $\begin{array}{c}\text { Labeled } \\
\text { Precursor }\end{array}$ & $\begin{array}{l}\text { Labelling } \\
\text { Reagent }\end{array}$ & References \\
\hline [methyl-11.C] thymidine and thymidylate* & $"$ & $\mathrm{H}^{11} \mathrm{CHO}$ & 100,301 \\
\hline [methyl-11 C] thymidine & $\infty$ & ${ }^{11} \mathrm{CH}_{3} \mathrm{I}$ & $301 a$ \\
\hline${ }^{11}$ C-1-methoxy-3-nitr:obenzene & $"$ & " & 302 \\
\hline$i^{\left.11_{C}\right]-5,6-\text { benzouracil }}$ & ${ }^{11} \mathrm{Co}$ & ${ }^{11} \mathrm{CoCl}_{2}$ & 106 \\
\hline [benzoyl carbony1-.11c]sp1roperidol & $\mathrm{H}^{\mathrm{Il}} \mathrm{CN}$ & $\mathrm{H}^{11} \mathrm{CN}$ & 303,304 \\
\hline 2-amino[2-11C]pyrimidines & $\left.{ }^{11} \mathrm{C}\right]$ guanidine & {$\left[{ }^{11} \mathrm{C}\right.$ ]guanidine } & 94,95 \\
\hline$[11 c]$ lodoaztipyrine & ${ }^{11} \mathrm{CO}_{2}$ & ${ }^{1} 1_{\mathrm{CH}_{3} \mathrm{I}}$ & 305 \\
\hline
\end{tabular}

*Biosynthesis.

a. acetate, propionate, acrylate, butyrate, Isobutyrate, trimethylacetate, pentanoate, hexanoate, heptanoate, cyclohexanecarboxylate, octanoate.

b. p-chlozobenzoate, 3,4-dimethoxybenzoate, p-hydroxybenzoate, salicylate, m-trifluozometiylbenzoate, p-phenoxybenzoate.

c. phenylacetate, 2-thlophenecarboxylate, 3-camphorcarboxylate, 1-naphthoate, 5-acenaphtienecarboxylate, 9-anthiacenecarboxylate, 9-phenanthrenecarboxilate.

d. $\left[1-11_{C}\right]$ peatane, nonane, undecane; $2-\left[{ }^{11} C\right]$ methyl-naphthalene, $\left[{ }^{1 l_{C}}\right.$ ] wetingl-benzene. 
Table 4. Fluorine-18 Labelled Compounds.

Compnund [18]Ary1 Fluorides

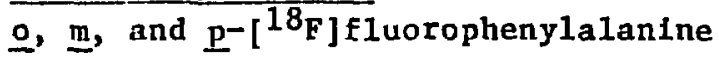
$\underline{m}$ and $\mathrm{p}-\left[{ }^{18_{F}}\right]$ fluorophenylalanine $L-P-[18$ F $]$ fluorophenylalanine* L-m- $[1.8 \mathrm{~F}]$ Eluorophenylalanine* $3-[18 \mathrm{~F}]$ fluurotyrosine L-3-[ ${ }^{18}$ F $]$ fluorotyrosine* 5 and $6-\left[{ }^{18}\right.$ F] fluorotryptophan $L-5$ and $6-\left[{ }^{18} \mathrm{~F}\right]$ fluorotryptophan* $\mathrm{p}-\left[18_{\mathrm{F}}\right]$ fluorobenzolc actd $\mathrm{p}-\left[{ }^{18_{\mathrm{F}}}\right]$ fluorober zolc acid 3,5-[18 F]dLE1;nOa-L-tyrosine

$5-\left[{ }^{18_{F}}\right]$ f1uoro-DOPA

5 [18 F] fluoro-DOPA $L-6-\left[{ }^{18}\right.$ F $]$ fluoro-DOPA

$6-\left[{ }^{18}\right.$ F] fluo rodopamine o- $\left[18_{F}\right]$ fluorohtppuric acid [18F]haloperidol. $\left[18_{F}\right]-\beta-(4-E 1$ uorobenzoy 1$)$ proplonic actd

\section{Labelied} Precursor

$\mathrm{LiB}^{18} \mathrm{~F}_{4}$
$\mathrm{Ne} / 18_{\mathrm{F}^{a}}$
$"$
$"$
$"$
$\mathrm{LIB} 18_{\mathrm{F}_{4}}$ or ${ }^{18 \mathrm{~F}^{-}}$
$\mathrm{Ne} / 18_{\mathrm{F}^{\mathrm{a}}}$

"

$18_{\mathrm{F}^{-}}$

$18_{F^{-}}^{-}$aq)

$$
18 \mathrm{~F}^{-}(\mathrm{aq})
$$$$
\mathrm{Ne} / 18_{\mathrm{F}} \mathrm{a}
$$$$
18 \mathrm{~F}^{-} \text {(aq) }
$$$$
\text { " }
$$

$\mathrm{K}^{18_{\mathrm{F}}}$

$18^{-}(a q)$
Labe111ng

Reagent

$\mathrm{L}^{1} \mathrm{~B}^{18} \mathrm{~F}_{4}$

$\mathrm{Ne} / 18_{\mathrm{F}^{\mathrm{a}}}$

"

"

"

"

$\mathrm{LIB}^{18} \mathrm{~F}_{4}$ or ${ }^{18} \mathrm{~F}^{-}$

$\mathrm{Ne} / 18^{\mathrm{F}}$

"

$\mathrm{HBB}^{18_{\mathrm{F}_{4}}}$

$\mathrm{K}^{18_{\mathrm{F}}-\mathrm{Cll}_{3} \mathrm{CO}_{2} \mathrm{H}}$

$18_{F^{-}}$(aq)

$\mathrm{Ne} / 18_{\mathrm{Fa}}$

$\mathrm{Bu}_{4} \mathrm{~N}^{18} \mathrm{~F}, \mathrm{XeF}_{2}$

$18_{\mathrm{F}}-$ (aq)

$\mathrm{K}^{18_{\mathrm{F}}}$

$18 F^{-}(a q)$
Labelling

Reaction Reference

Schiemann $\quad 306$

"

"

,

,

$"$

$"$

"

"

"

"

Schiemann

nucleophtilc substitution

"

"

electrophilic fluorination

Schlemann

exchange

318

Schlemann

319

136

307,308

308

136

308

309

136,308

136,133

310

311

$312-314$

308

315-316

" 
Table 4. Fluorine-18 Labelled Compounds (continuation).

\begin{tabular}{|c|c|c|}
\hline Compound & $\begin{array}{l}\text { Labelled } \\
\text { Precursor } \\
\end{array}$ & $\begin{array}{l}\text { Labell1ng } \\
\text { Reagent }\end{array}$ \\
\hline$\left[{ }^{18}\right.$ F]haloperidol & $\mathrm{H}^{18_{\mathrm{F}}}$ & $\mathrm{Cs}^{18_{\mathrm{F}}}$ \\
\hline$\left[1_{\text {F J spiroperidol }}\right.$ & $"$ & $"$ \\
\hline$\left[{ }^{18} \mathrm{~F}\right]$ fluorobenzene & 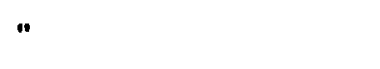 & • \\
\hline $4^{1}-\left[1_{F}^{18}\right]$ fluoroantipyrine & ${ }^{18} \mathrm{~F}^{-}(\mathrm{aq})$ & $18_{F^{-}}(\mathrm{aq})$ \\
\hline$\left[{ }^{18} \mathrm{~F}\right]$-ary1fluorides ${ }^{b}$ & $"$ & $\mathrm{HB}^{1} 8_{\mathrm{F}_{4}}$ \\
\hline$\left[18_{F}\right]-f$ luorobenzene & {$\left[18_{F}\right] F_{2}$} & {$\left[18_{F}\right] F_{2}$} \\
\hline$\left[{ }^{18} \mathrm{~F}\right]-\mathrm{P}^{- \text {f1uoronitrobenzene }}$ & $"$ & $\mathrm{Rb}^{18} \mathrm{~F}$ \\
\hline$\left[{ }^{18} \mathrm{~F}\right]-\mathrm{p}$-fluorobenzonftrile & $"$ & $"$ \\
\hline \multicolumn{3}{|c|}{ [18 F]F1uorocarboxy11c Ac1ds and Der1vatives } \\
\hline$\left[{ }^{18} \mathrm{~F}\right]$ fluoroacet $1 \mathrm{c}$ actd & $18_{\mathrm{F}^{-}}(\mathrm{aq})$ & Dowex $1 \times 4\left(18_{F^{-}}\right)$ \\
\hline$\left[{ }^{18}\right.$ F]fluoroacetanide & $"$ & $"$ \\
\hline $2-\left[{ }^{18} \mathrm{~F}\right]$ fluorohexanoic acid & $"$ & $"$ \\
\hline $2-\left[{ }^{18}\right.$ F $]$ fluorotetradecanoate & $"$ & $"$ \\
\hline $2-\left[{ }^{18}\right.$ F $]$ fluoroacetic actd, ethyl ester & $"$ & $"$ \\
\hline $2-\left[^{18} \mathrm{~F}\right]$ fluoroacetic actd, ethyl ester & $\mathrm{Ne} / /^{18} \mathrm{~F}^{\mathrm{a}}$ or $0_{2} / /^{18_{\mathrm{F}}^{\mathrm{a}}}$ & $\mathrm{K}^{18 \mathrm{~F}}$ \\
\hline $2-\left[{ }^{18} \mathrm{~F}\right]$ fluorovaleric ac1d, methyl ester & $18 \mathrm{~F}^{-}(\mathrm{aq})$ & Dowex $1 \times 4\left(18_{F^{-}}\right)$ \\
\hline $2-\left[{ }^{18}\right.$ F $]$ fluoropropanolc acld, methyl ester & $"$ & $\mathrm{~K}^{18} \mathrm{~F}($ anhyd $)$ \\
\hline $16-\left[{ }^{18} \mathrm{~F}\right]$ fluorohexadecanolc tectd & $"$ & $\mathrm{~K}^{1 B} \mathrm{~F}$ (molten acetainfde) \\
\hline $17-\left[18^{F}\right]$ fluoroheptadecanolc actd & $"$ & $"$ \\
\hline $2-[18$ F $]$ fluorostearic acid & $"$ & $"$ \\
\hline $9,10-\left[1^{18} \mathrm{~F}\right]$ fluorostearic acid & $"$ & $"$ \\
\hline $7-\left[{ }^{18} \mathrm{~F}\right]$ fluoropa1mitic acid & $H^{18} F$ (anhyd) & $\mathrm{Cs}^{18} \mathrm{~F}$ \\
\hline
\end{tabular}

\begin{tabular}{|c|c|}
\hline $\begin{array}{l}\text { Label11ng } \\
\text { Reaction }\end{array}$ & Reference \\
\hline $\begin{array}{l}\text { trlazene } \\
\text { decomposition }\end{array}$ & $321-322$ \\
\hline$"$ & 323 \\
\hline$"$ & 324 \\
\hline Schlemann & 325 \\
\hline$"$ & 310 \\
\hline $\begin{array}{l}\text { electropht1 ic } \\
\text { substitut1o }\end{array}$ & 326,327 \\
\hline$"$ & 328 \\
\hline$"$ & 328 \\
\hline exchange & $329-330$ \\
\hline " & 329 \\
\hline " & 329 \\
\hline " & 329,330 \\
\hline " & 331 \\
\hline exchange & 137 \\
\hline$"$ & 331 \\
\hline $\begin{array}{l}\text { rucleophtilc } \\
\text { substitution }\end{array}$ & 331 \\
\hline exchange & $332-333$ \\
\hline • & $332-333$ \\
\hline$"$ & $115,332-33$ \\
\hline$"$ & $332-333$ \\
\hline nucleophi1 ic & 334 \\
\hline
\end{tabular}


Table 4. Fluorine-18 Labelled Compounds (continuation).

Labelling Reagent

Fluorosteroids

$\overline{2,4-[18 \mathrm{~F}] \mathrm{difluoroestrone}}$

$18^{-}-(a q)$

4- $\left[{ }^{18} \mathrm{~F}\right] \mathrm{f} 1$ uorotes tosterone

21- $\left[{ }^{18}\right.$ F $]$ f1uoroprogesterone

21- $\left[18_{F}\right]$ f1uoropregnenolone-3-acetate

$3-\left[18_{F}\right]$ fluorocholestene

$18_{\mathrm{F}}$

$4-\left[{ }^{18} \mathrm{~F}\right]$ fluoroestrone and

$4-\left[18_{F}\right]$ fluoroestradiol

$\mathrm{Ne} / 18_{\mathrm{Fa}}^{\mathrm{a}}$

3-acetoxy-5-hydroxy-6-[18 F] fluorocholestane $18_{F}$.

3-acetoxy-5-[18 $\mathrm{F}]$ fluoro-6-hydroxycholestane "

cholestery $1\left[{ }^{13} \mathrm{~F}\right.$ ] fluoride

$\left[{ }^{18_{F}}\right]$ Fluorosugars

6-deoxy-6-[ ${ }^{18_{F}}$ ] fluoro- $\alpha-D-g a l a c t o p y r a n o s e$

$18_{\mathrm{F}}-(\mathrm{aq})$

$B-D-g 1$ ucosy $1-\left[{ }^{18_{F}}\right]$ fluoride

2-deoxy-2- $\left[{ }^{18_{F}}\right]$ fluoro-D-glucose

2-deoxy-2-[ $\left[8_{\text {F }] \text { fluoro-D-mannose }}\right.$

3-deoxy-3-[ $\left.18_{F}\right]$ f1uoro-D-glucose
$"$

$18 \mathrm{~F}\left[F_{2}\right]$

"

$11^{18}$ (anliyd)
$\mathrm{K}^{18} \mathrm{~F}-\mathrm{CH}_{3} \mathrm{CO}_{2} \mathrm{H}$

"

$\mathrm{K}^{18} \mathrm{~F}[18-\mathrm{crown}-6]$

"

$\mathrm{Ag}^{18} \mathrm{~F}$

$\mathrm{Ne} / 18_{\mathrm{F}^{\mathrm{a}}}$

$\mathrm{B}^{18} \mathrm{~F}_{3}$

"

-

$\mathrm{Et}_{4} \mathrm{~N}^{18} \mathrm{~F}$

$\mathrm{Ag}^{18_{\mathrm{F}}}$

$18_{\mathrm{F}}\left[\mathrm{F}_{2}\right]$

$\operatorname{Cg}^{1 B} \mathrm{~F}$
Labelling

Reaction

nucleophilic substitution

"

nucleophtlic substitution

"

nucleophilic substitution

Schtemann

$\mathrm{H}^{18_{\mathrm{F}} \text { addition }}$

"

-

nucleophilic

Bubstitution

electrophi11c addition

$72-73,344-349$

nuclenphititc uubstitution
343

276

344

Reference

311

311

$335-338$

339

340-341

133,134

134

134

$124,350-352$ 
Table 4. Fluorine-18 Labelied Compounds (continuation).

Labelling

Reagent

$\frac{\left[{ }^{18} \text { F }\right] \text { Fluoropyrimidines }}{5-\left[^{18} \text { F fluorouracil }\right.}$

Precursor

$5-\left[{ }^{18} \mathrm{~F}\right]$ fluoro-2'-deoxyuridine

$5-\left[{ }^{18} \mathrm{~F}\right]$ fluorouridine

$5-\left[18_{F}\right]$ trifluoromethyluract1

$2^{\prime}-f 1$ uoro-2'-deoxyuridine

$18_{\mathrm{F}\left[F_{2}\right]}$

$"$

"

$\mathrm{Ag}^{18} \mathrm{~F}$

$18_{\mathrm{F}}$.
$18_{\mathrm{F}^{-}}^{-}(\mathrm{aq})$

Miscellaneous $18 \mathrm{~F}-$ L

$1-\left[{ }^{18} \mathrm{~F}\right]$ fluoroliexane

benzoy $1{ }^{18} \mathrm{~F}$ ] fluoride

benzy1 [ ${ }^{18_{F}}$ ]fluoride

$p_{\text {-toluenesulfony } 1}$ [ $^{18_{F}}$ ] fluorlde

[18 F]trifluoromethylbenzane and derivatives "

$2-\left[{ }^{1 B_{F}}\right]$ trlfluoromethylbenzothiazole

$2-\left[{ }^{18}\right.$ F $]$ trif luoromethyl phenothlazine

$3-\left[{ }^{18}\right.$ F $]$ fluoro-p-menthane

diethylamino sulfur ${ }^{18_{F}}$ ]trifluoride

$3-\left[{ }^{18_{F}}\right.$ ]fluoropropanol

$2-\left[{ }^{18} \mathrm{~F}\right]$ fluoroethanol

$2-\left[18_{F}\right]$ fluoroethanol

\section{" \\ $"$ \\ " \\ " \\ .}

$"$

"

${ }^{11}{ }^{18} \mathrm{~F}$ or ${ }^{18} \mathrm{~F}\left[\mathrm{~F}_{2}\right]$ $18_{\mathrm{i}-}-$ (al)

"

"
$\mathrm{K}^{18} \mathrm{~F}$ [18-crown-6]

Labe111ng

$18 \mathrm{~F}-\mathrm{res} \ln$

•

"

$\mathrm{Et}_{4} \mathrm{~N}^{18} \mathrm{~F}$

$\mathrm{K}^{18_{\mathrm{F}}}$

$\mathrm{K}^{18} \mathrm{~F}$ [18-crown-6]

"

"

$\mathrm{K}^{18_{\mathrm{F}}}$

$\mathrm{H}^{18} \mathrm{~F}$ or ${ }^{18} \mathrm{~F}_{\left[\mathrm{F}_{2}\right]}$

$\mathrm{K}^{18^{\mathrm{N}}}$

$\mathrm{K}^{18} \mathrm{~F}$

Dowex $1 \times 4\left({ }^{18} \mathbf{F}^{-}\right)$
Reaction

electrophtlic addition

"

1"

exchange

nucleophilic substitution

nucleophilic displacement

Reference

353-354

355-356

357

358

359

"

"

"

"

exchange

$"$

"

nucleophil ic subst ltution

exchange

$"$

"

exchange
$360-361$

$360-361$

360-361

360-361

360

358

358

358

362

128

362

362

329 
Table 4. Fluorine-18 Laielled Compounds (continuation).

ה $\quad$ Compound

$2-\left[{ }^{18} \mathrm{~F}\right]$ f1uoroethanol

$2-\left[18^{F}\right]$ fluoroethanos?

methy1 [ ${ }^{18_{F}}$ ] fluoride

ethyl [ $18_{\mathrm{F}}$ ] fluoride

$\left[18_{F}\right]$ fluoroa 1 kanes $^{c}$

$\left[{ }^{18} \mathrm{~F}\right]$ oxy tocin

[ $\left.{ }^{18} \mathrm{~F}\right]$ fluorotrich1oromethane dichloro[ ${ }^{18} \mathrm{~F}$ ]d1 fluaromethane $4-\left[{ }^{18_{F}}\right]$ fluoroant pyrine

[18 $\left.{ }^{18}\right]$ fluoronitriles

$6-\left[{ }^{18}\right.$ F $]$ fluoro-9-benzyl purine

$$
\text { Labelled }
$$

Precursor

$\mathrm{H}^{18} \mathrm{~F}$ (anhyd)

.

"

"

${ }^{18} \mathrm{~F}^{-}(\mathrm{aq})$

${ }^{18} \mathrm{~F}^{-}$(aq)

"

"

${ }^{\left.18_{\mathrm{F}\left[\mathrm{F}_{2}\right.}\right]}$

$18_{\mathrm{F}^{-}}$(aq)

$18_{\mathrm{F}}$.
Labell1ng

Reagent

$18_{\mathrm{F}-D A S T}$

$\mathrm{Cs}^{18} \mathrm{~F}$

$18_{\mathrm{F}-\mathrm{DAST}}$

$\operatorname{Et}_{4} \mathrm{~N}^{18} \mathrm{~F}$

$\mathrm{K}^{18} \mathrm{~F}_{-\mathrm{CH}_{3}} \mathrm{CO}_{2} \mathrm{HI}$

$\mathrm{Ag}^{18} \mathrm{E}$

$\mathrm{Ag}^{18_{\mathrm{F}_{2}}}$

$\left.{ }^{18} \mathrm{~F}\right] \mathrm{F}_{2}$

Dowex $1 \times 4\left({ }^{18} \mathrm{~F}^{-}\right)$

$\mathrm{Ag}^{18} \mathrm{~F}$
Labell1ng Reaction

substitution

nucleophilic substitution

substitution

"

nucleophilic substitution

nucleophilic substitution

"

"

electroph111c addition

exchange

nucleophilic substitution

\section{Reference}

128

363

128

128

364

311

365

365

$366-367$

\footnotetext{
* Blosynthesis.

a. $18_{\mathrm{F}}$ species not identifled.

b. 18 F-1abeled fluorobenzene, fluoroblpheny1, 2-fluoronaphthalene, 1,3-chlorofluorobenzene,

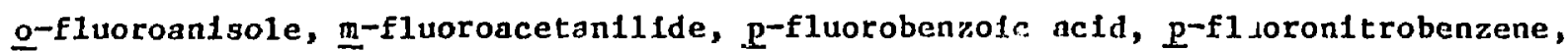
1-f1uoro-2, 3,5-tribromobenzene.

c. $\mathrm{RF}\left(\mathrm{R}=\mathrm{CH}_{3}, \mathrm{C}_{2} \mathrm{H}_{5}, \mathrm{n}-\mathrm{C}_{3} \mathrm{ll}_{7}, \mathrm{I}-\mathrm{C}_{3} \mathrm{Il}_{7}\right)$.
} 
Table 5. Enzymatic Syntheses of ${ }^{13} \mathrm{~N}-\mathrm{L}-\mathrm{Am} 1$ no Actds.

\begin{tabular}{|c|c|c|c|}
\hline${ }^{13} \mathrm{~N}$-Source & Enzyme & 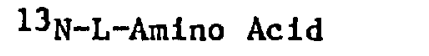 & References \\
\hline 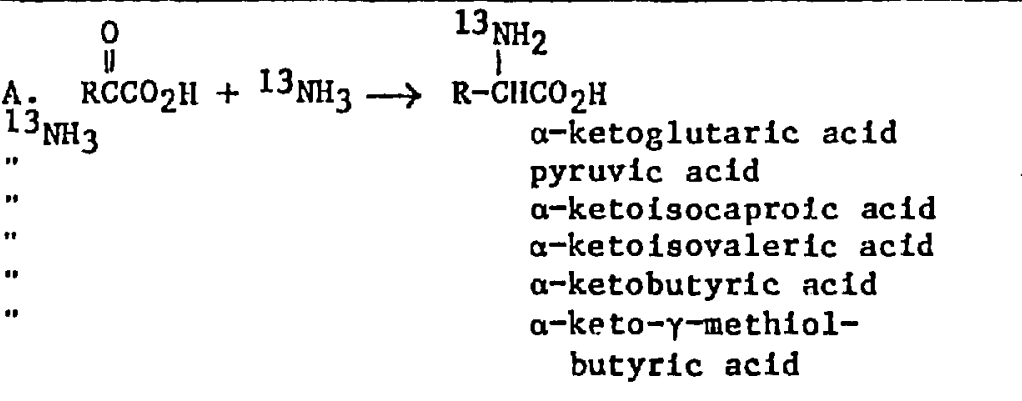 & $\begin{array}{l}\text { GADa } \\
" \\
" \\
" \\
"\end{array}$ & $\begin{array}{l}\text { glutamic acid } \\
\text { alanine } \\
\text { leucine } \\
\text { valine } \\
\alpha \text {-aninobutyric acid } \\
\text { L-nethionine }\end{array}$ & $\begin{array}{l}152,154,368-375 \\
152,373-374,376-377 \\
152,373 \\
152,373 \\
373 \\
373\end{array}$ \\
\hline 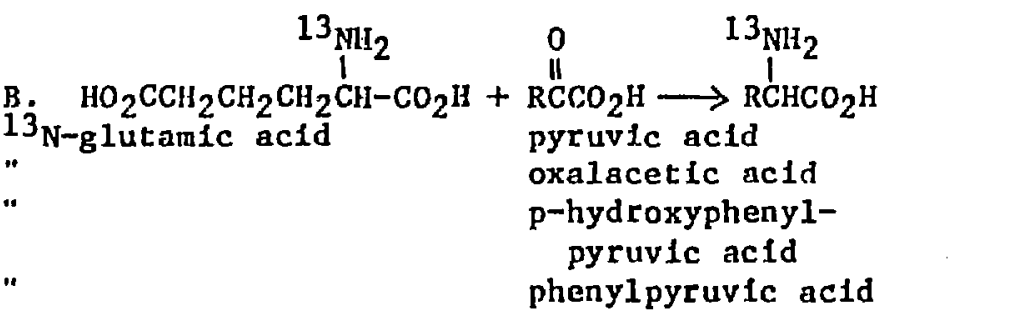 & $\begin{array}{l}\operatorname{GTP}^{b} \\
\operatorname{GOT}^{\mathrm{c}} \\
"\end{array}$ & $\begin{array}{l}\text { alanine } \\
\text { aspartic acid } \\
\text { tyrosine } \\
\text { phenylalanine }\end{array}$ & $\begin{array}{l}369 \\
370,374 \\
378 \\
378\end{array}$ \\
\hline 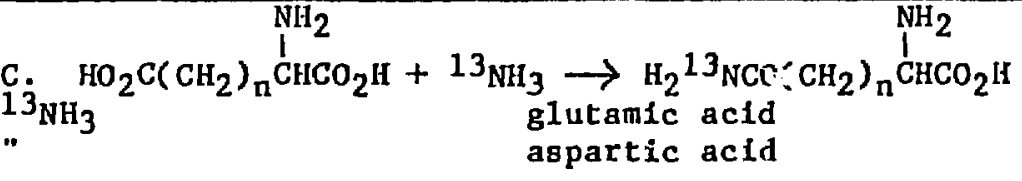 & $\begin{array}{l}G^{d} \\
A S^{e}\end{array}$ & $\begin{array}{l}\text { [anide-13 N] }{ }^{13} \text { lutamine } \\
\text { [amlde-13N] asparaglne }\end{array}$ & $\begin{array}{l}152,154,368,370,374,379 \\
380-381\end{array}$ \\
\hline
\end{tabular}

\footnotetext{
a. glutamlc acid dehydrogenase

b. glutanate-pyruvate transaminaze

c. glutamate-oxaloacetate transaminase

d. glutamine synthetase

e. asparagine synthetase
} 
Table 6. Nitrogen-13 Labeled Compounds Prepared by Direct Chemical Synthesis.

\begin{tabular}{|c|c|c|}
\hline Compound & $\begin{array}{c}\text { Labelling } \\
\text { Reagent }\end{array}$ & Reference \\
\hline $1-(2-c h$ loroethyl $)-3-c y c l o h e x y 1-1-[13 \mathrm{~N}]$ nitrosourea & $\mathrm{H}^{13} \mathrm{NO}_{2}$ & 158,161 \\
\hline 1,3 -bis(2-chloroethyl)-1-[13N]nitrosourea & $"$ & 459,161 \\
\hline$\left[{ }^{13} \mathrm{~N}\right]$ streptozotocin & $"$ & 382 \\
\hline$\left[{ }^{13} \mathrm{~N}\right] \mathrm{n} 1 \mathrm{trosocarbaryl}$ & $n$ & 382 \\
\hline$\left[13_{\mathrm{N}}\right]$ urea & ${ }^{13} \mathrm{Na}_{3}$ & 383 \\
\hline$\left[{ }^{13} \mathrm{~N}\right]$ asparagine & $"$ & 384 \\
\hline$\left[{ }^{13} \mathrm{~N}\right]$ octylamine & n & 385 \\
\hline$\left[{ }^{13} \mathrm{~N}\right]$ amphetamine & 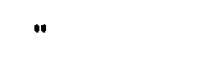 & 386 \\
\hline
\end{tabular}




\section{The Synthetic Strategy}

In developing a practical synthetic approach leading to a new short-lived radiotracer, the advantage of beling acqualnted with the general methods and new developments in synthetic organlc chemistry cannot be overemphasized. This is especially true consldering the difficulties in synthesizing relatively complex molecules from a limited number of precursor molecules within the restricted time period imposed by the half-life of the nuclide. As is the case in approaching any problem in synthetic organlc chemistry, the first step should be a detailed search of the relevant chemical 1iterature. A search of the unlabeled compound itself or model compounds may suggest routes which can be modifled to be compatible with the half-life and precursor restrictions. In some cases, synthetic strategles involved in related syntheses of short-lived tracers or carbon-14 labeling can serve as a gulde. Tables $3,4,5$ and 6 provide listings of $11_{C}, 18_{F}$ and $13_{\mathrm{N}}$ labeled compounds along with the labeled precursor from which they were synthesized. In general, the following two factors influence the potentlal adaptation of a given syathetic approach to high specific activity labeling with short-lived nuclides.

1. The Iaaction should proceed in high radiochemical yield.

2. The reaction should be one in which the radiolsotope undergoes low or no dilution with carrier.

The initial literature search and the planning of the synthetic approach is usually followed by a more detalled investigation of reagents, protecting groups etc. A brief guide to location of useful information on the use of the literature in organic synthesis appears in Appendix 1. A selected list of review articles on the general topics of organic synthesis with positron emitting nuclides is Included In Appendix 2. "Non-synthet1c" techniques (164) including recoil labeling, radiation labeling, and excitation labeling to produce radiotzacers will not be covered here, although some of the sluple labeled precissors listed in Table 2 are produced using these methods.

\section{Optimization of Reaction Rates}

In contrast to most problems in synthetic organlc chemistry where the rate of a chenical reaction is not a great concern if it is within a reasonable time scale, the problem of reaction rates as well as the time scale of experfmental qanfpulations is a primary concern to labeling with short-lived posttron emitters. Soth classical chemical synthesis and blosyntinesis have been used In the incorporation of positron-emttefing nuclides Into radiotracers. The optimal yield and reaction time can be derived from rate equations fncluding the radioactive decay constant. This has been 
validated using a model reaction ( $1 . e$. the synthesis of $1-\left[{ }^{1} l_{C}\right]$-methoxy-3-nitrobenzene starting with $\left[{ }^{1 l_{C}}\right]$ methyliodide) (302). The Incorporation of any short-lived nuclide into radiotracers usually requires the adjustment of such reaction conditions as temperature, solvents, substrate reactivity and reagents so that the synthesis, purffication and forinulation for injection can be carrled out within a few half-lives of the nuclide. This imposition of a restricted time scale on the synthetic approach is somewhat unique to labeling with short-lived nuclides and challenges the ingenulty of the chemist. Some examples serve to illustrate these points.

Temperature effects: It is important to investigate a range of temperatures in carrying out a given transformation. As an example, the conversion of ${ }^{11_{C}}$-labeled nitrile (1) to ${ }^{1 l_{C}}$-spiroperidol (2) by reaction with $\underline{p}$-fluorophenylmagnesium bromide proceeded rapidly at $130^{\circ}$ whereas so reaction was observed at $25^{\circ}$. The elevation of the reaction temperature required

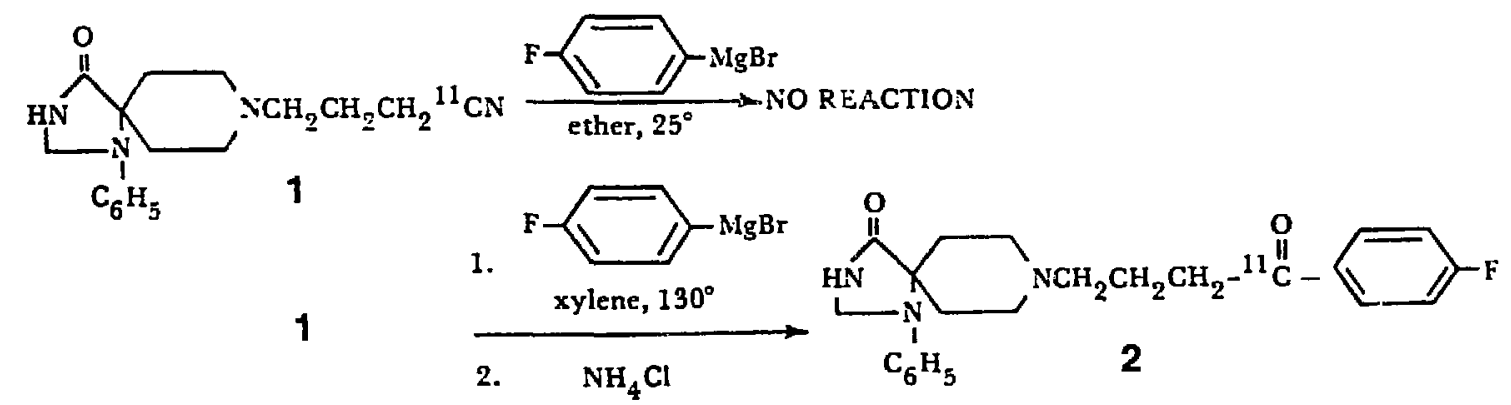

the substitution of xylene for ether as the reaction solvent another factor which probably Increased the reaction rate ( 304$)$.

Substrate Structure, Reducing Agents, Protective Groups and Solvents

There is a large body of information concerning the effect of structure on the degree of reactivity of organic molecules to various reagents. This Information can be exploited when designing synthetic approaches to short lived radiotracers. Foz example, the reaction of protected substrate $\underline{3}$ with

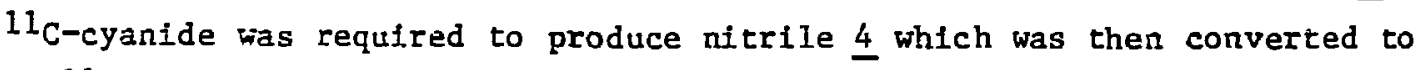
$\left[1-11_{C}\right]-2-d e c k g-D-g i u c o s e, \underline{5}$ (277). The 20 minute half-1ife of carbon-11 required that this step be rapid. The rates of displacement of three different leaving groups on the protected substrate $\underline{5}$ were investigated. When the leaving group was tosylate $\left(x=0 \mathrm{SO}_{2} \mathrm{C}_{7} \mathrm{H}_{7}\right)$ the reaction required several days at room temperature. However, when the leaving group was lodide the. reaction only required $5 \mathrm{~min}$ at $120^{\circ}$. The most satisfactory leaving group, however, was trifluoromethanesulfonate $\left(\mathrm{x}=\mathrm{OSO}_{2} \mathrm{CF}_{3}\right)$ which is well known for 
its reactivity in nucleophilic displacenent reactions and reacts in 5 minutes at $25^{\circ}$. The nitrile 4 was not purified before carrying out step 2 .<smiles>[Y]C[C@H](O)[C@H](OC(C)(C)C)[C@H]1COC(C)(C)O1</smiles>

3

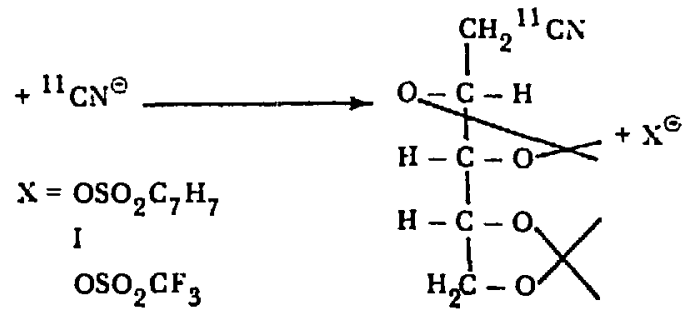

4

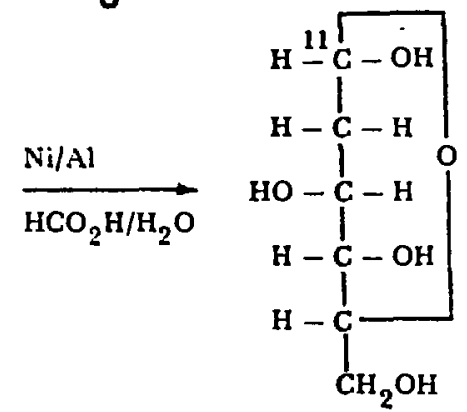

5

It was found that iodide fon but not trifluoromethanesulfonate anion present in the reaction mixture after the displacement poisoned the cataiytic reduction (Step 2). It is a time advantage to be able to carry out the second step of the synthetic sequence without an intermediate purfification step, but as the above synthesis polnts out, the interference of reaction prciucts as well as reagents may require modification of the substrate.

Another related tactic which has been used to adyntage is the simultaneous accomplishnent of two transformations in one step. For example in the second step of the ${ }^{1 I_{C}}$-2DG synthesis described above, the protective isopropylidene groups which are actd lablle are cleaved during the reduction

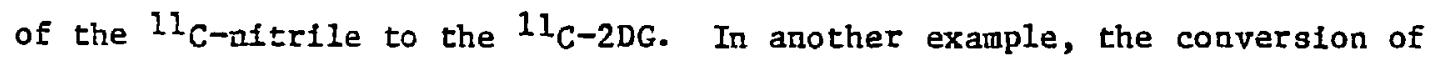
nitrile (ㅁ) to ${ }^{1 I_{C}}$-labeled dopamine $\mathrm{HCl}$ (ㄱ) involved the simultaneous reduction of the nitrile to an amine and renoval of the benzyl protective groups .

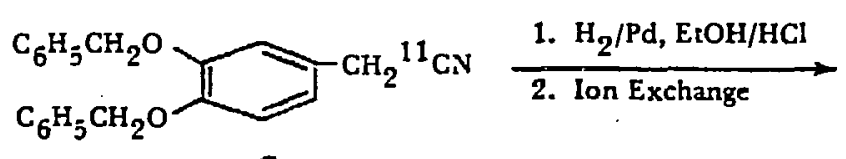

6<smiles>Oc1ccc(CCCCC[Si]Cl)cc1O</smiles> 
The use of Ion exchange as a puriflcation step allowed the separation of the ${ }^{11} \mathrm{C}$-dopanine-HCl from toluene and other non-amine impurities in the reaction mixture (252).

An important consideration in the design of a synthetic strategy is the avallabllity of a wide variety of reducing agents which differ in thelr functional group selectivity can be used to advantage in the selective reduction of functionai groups in complex molecules (see references in

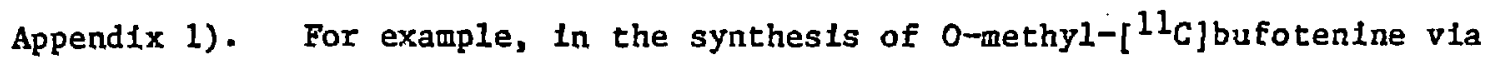
the reductive methylation of 0-methyltryptamine ( 8 ), the conventional

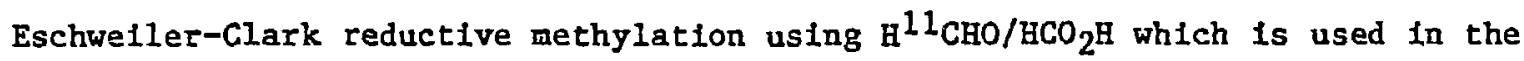
preparation of many $\mathrm{N}-\left[{ }^{11} \mathrm{C}\right]$ methylamines (see Table 3 ) lead to the undesired tetrahydrocarboline derivative, (9), whereas the use of a milder reducing

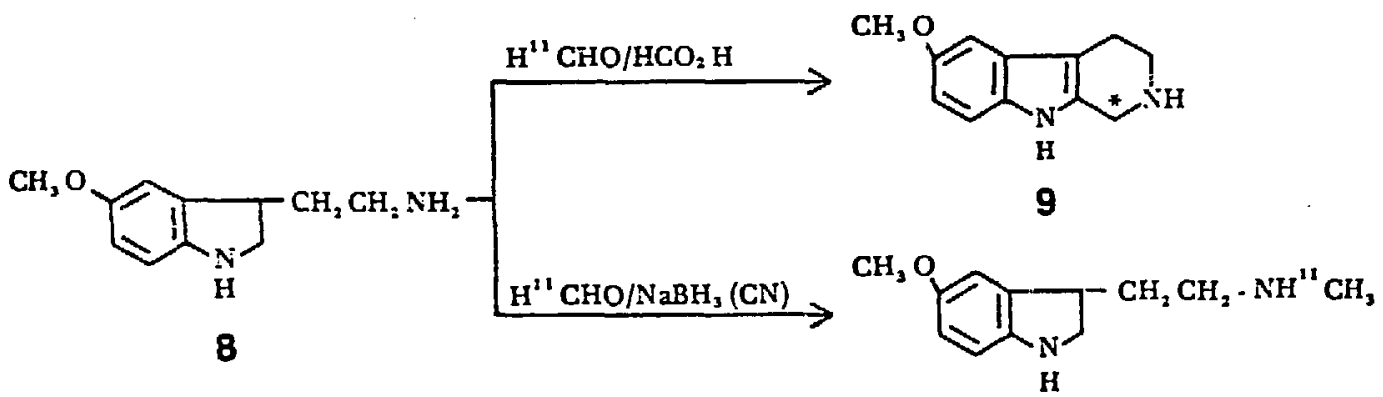

O-methyl-[" C] bufotenine

agent, sotium cyanoborohydride, resulted in the desired transformation (224). In another exanple ${ }^{11_{C}}$-labeled cyanohydrin (10) is reduced to ${ }^{11_{C}}$-labeled norepinephrine hydrochlortde (11) using borane, a Lewls actd type reducing agent (253).

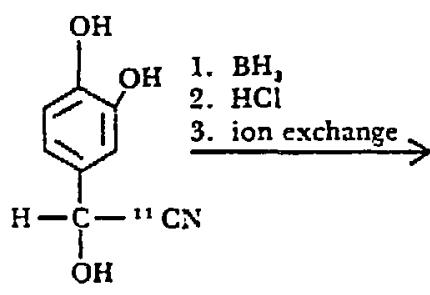

10

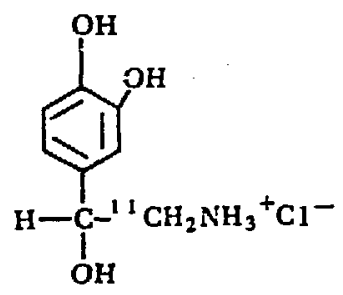

11

Attempis to carry out this transformation with lithium aluminum hydride were unsuccessful probably due to the presence of the catechol molety which formed Insoluble complexes with the reducing agent and to the Instability of the 
substrate in a basic medium. Catalytic hydrogenation could not be used in this case because of the known hydrogenolysis of benzyl alcohols.

The importance of the wise choice of protective groups in rapid organic synthesis should be reemphasized. The presence of more than one reactive center in the same molecule often complicates the transformation of a single functional group and requires protecting these other reactive functional groups during the synthesis. However it is also essential that the protective group be removed rapidly after the desired reaction step and that the protective molety be separable from the product. Along this line, the development of many protective groups of varying stabllity in different chemical environgents has played an important role in synthetic organic chemistry (see Appendix 1). The application of their diverse properties to problems in rapid organic synthesis is an important aspect of developing reasonable synthetic approaches to complex short-lived radiotracers.

Following the above examples, solvent effects can be used to enhance the rates of a varfety of chemical reactions. This is most dramatically illustrated by the use of dipolar aprotic solvents to increase the reactivity of anions in nucleophilic displacement reactions. For example, in the reaction of cyenide ion with methyl lodide, the reaction is $>5 \times 10^{5}$ faster in dimethylformamide (DMF) than in water. This rate enhancement is due to the poor solvation of the cyanide ion in DMF coupled with a favorable solvation of the polarized charged transition state. There is a large amount of information ccaceraing the use of dipolar aprotic solvents to enhance reaction rates (387). These solvents have been used many times in the rapid synthesis of ${ }^{11}$ C-labeied altriles (Table 3 ).

\section{Specific Activity and Stolchiometry}

Specific activity is frequently defined as radioactivity per unit of mass (388). The maximum specific activity for a radionuclide is a function of the half-life oz the nuclide and is attained when there is no dilution by other isotopes of the same element. This is referred to as the carrier-free (CF) state. In practice, it is possible to approach the CF state within an order of nagnitude for sone radionuclide species. However, it is difficult to exclude the stable nuclide in most cases. For example, the unintentional and largely unavoldable dilution of ${ }^{11} \mathrm{C}$ with ${ }^{12} \mathrm{C}$ is approximately $1: 3000$ in the

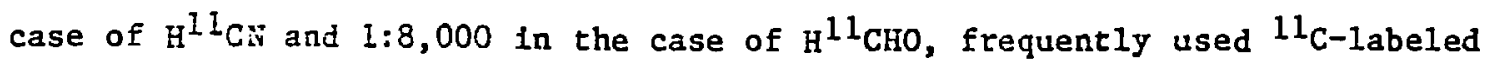
precursors.

The need for a consistent terminology for Identifying the exteat of dilution of the radiotracer has been recognized and the use of the following three unambiguous terms has been recently suggested $(303,389)$ : 
Carrier Free, CE, should mean that the radionuclide or stable nuclide is not contaminated with any other radio or stable nuclide of the same element.

No Carrier Added, NCA, should apply to an element or compound to which no carrier of the same element or compound has been intentionally or otherwise added during its preparation. Carrier Added, CA, should apply to any element or compound to which a known amount of carrier has been added.

It should be clear that these terms refer, to a specific position or positions when applied to a molecule.

When the specific activity of the short-lived radlotracer is very near CF, the mass of the product is not detectable by ordinary chemical or spectroscopic means. Hith $\mathrm{NCA}^{11} \mathrm{C}$-labeled radlotracers the specific activity of the product can be determined by measuring the mass of a large (radloactivity) amount labeled precursor using sensitive analytical techniques. This was done in the case of $\mathrm{B}^{11} \mathrm{CN}$, and this value can be used to calculate the speclfic activity of radiotracers which are synthesized from $\mathrm{H}^{11} \mathrm{CN}$ (304). It has been possible to determine the specific activity of NCA

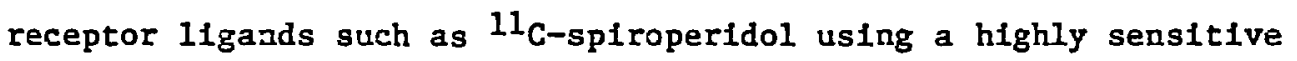
radioreceptor assay method (304).

When the maximum specific activities for the pasitron emitters ${ }^{11_{C}},{ }^{18} \mathrm{~F}$ and $13 \mathrm{~N}$ is compared to ${ }^{14} \mathrm{C}$ and ${ }^{3} \mathrm{H}$ (Table 1 ) it is apparent that far less mass is assoctated with $\mathrm{CF}$ or NCA levels of tracers labeled with the positron emitters than with carbon-14 or tritium. With NCA or CF short-1ived radiotracers, the mass of the tracer is at the same time usually below the threshold where any physlological response is invoked but where there is sufficient radioactivity assoclated with this mass to be detected with statistical significance. For example, the radioactive concentration in the tissue of interest should be in the range $0.1-0.5 \mu \mathrm{Cl} / \mathrm{g}$ to provide statistically significant count rates with present PET instruments. In using positron enitting ligands to study receptors where the receptor-11gand dissociation constant is $\sim 10^{-9} \mathrm{M}$, the specific activity of the radiotracer should be in the range 100-500 C1/mmol at the time of measurement (52). Furthermore, even highly toxic wolecules can be studied if the radiotracer can be prepared in sufficiently high specific activity.

While the high specific activity possible with positron emitting tracers is frequently an essential requirement for tracer studies in humans, it places more restrictions on the syathetic approach. This is manifested in terms of the scale of the reaction and the stolchiometry. For example, in a NCA 
synthests with $\mathrm{Na}^{11} \mathrm{CN}$ (speciflc activity: $2000 \mathrm{Ci} / \mathrm{mmol}$ ) the quantity of $\mathrm{NaCN}$ used if one starts with $100 \mathrm{mCl}$, is $50 \mathrm{nmol}$. With this small quantity of ${ }^{11} \mathrm{C}$-labeled $\mathrm{NaCN}$, all other substrates or reactants used in the synthesis are necessarily in huge excess. This can often pose difficulties when an excess of a given reagent cannot be tolerated. For example, in the synthesis of

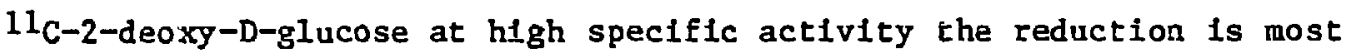
conveniently carried out using Raney alloy (NI-AI) in acldic solution $\left(\mathrm{HCO}_{2} \mathrm{H} / \mathrm{H}_{2} \mathrm{O}\right)$ (277). Since the reduction is carried out in acidic solution the imine formed is hydrolyzed to the aldehyde in situ, thus minimizing the amount of amine formed. This in situ hydrolysis makes the relative ratio of the nitrile to reducing agent unimportant in contrast to the use of a hydride reducing agent (see ref. 390 for a discussion of the problems of reduction of $\mathrm{R}^{11} \mathrm{CN} \rightarrow \mathrm{R}^{11} \mathrm{CEO}$ ).

Dealing with high specific activity labeled precursors also requires that the synthesis be carried out on a very small scale. This is important both in terms of the relative ease and speed with which one can handle small quantities of reagents and solvents and in the interest of introducing the minimum amount of substances to be removed in the final purification. It is also inportant in teras of avolding the unintentional introduction of impurities which way negatively influence the course of the reaction. One thing which must be kept in mind is that the substrate vhich will undergo reaction with the labeled jiecursors be in sufficient concentration to react both with the labeled precursors and other competing reactants which may be present in the reaction mixture. Even though the labeled precursor may be far more reactire than other species in the mixtures relatively higher concentrations of less reactive species in the reaction mixture may consume all of tive substrate before the desired labeling reaction may take place. For example, in the synthesis of labeled nitriles from ${ }^{11_{C}} \mathrm{-labeled}$ cyanide, the $\mathrm{H}^{11} \mathrm{CN}$ from the target is trapped in sodium hydroxide. Therefore since the reaction mixture contains both ${ }^{11} \mathrm{CN}^{-}$and $\mathrm{OH}^{-}$as nucleophiles which can react with an added substrate, the anount of the substrate should be equal to the anount of the ${ }^{11} \mathrm{CH}^{-}$plus $\mathrm{OH}^{-}$. Some of the problems of ultramicro-scale organic syrthesis have been addressed recently using ${ }^{11} \mathrm{C}$ labeling with a number of different types of reactions in which the relative ratios of $11_{C}$-pracursor and other reactants varied (391). The influence of equilibrium displacerent, competing reactions and solvent impurities was examined. 
Expression of Yields and Specific Activity with Short-Lived Nuclides

When describing radiotracer synthesis with short-lived radionuclides, it is essential that there is no ambiguity in expression of quantities of radioactivity, specific activity and radiochemical yields. This requires the decay correction of all relevant ylelds to some reference time point. This time point is most conveniently taken as the time of the end of cyclotron or accelerator bombardment (EOB). The use of EOB as a reference time point normalizes the varlable of synthesis time. In cases where it is useful to express the yleld at the end of the synthesis time, EOS should be used to denote this. The format is generally to use the expression EOB directly following the fleld (1.e. 300mCl (EOB)). When EOS is used, the synthesis time should be included ( $1 . e .20 \mathrm{mCl}$ (EOS, $45 \mathrm{mln}$ )). In this way radiochemical ylelds can be readily calcul.ated and there are no ambigulties having to do with synthesis time.

\section{Blosynthetic Tactics}

Blosyntheric approaches to short lived radiotracers have been revlewed (392) and have the advantages of speed and the introduction of asymmetric centers lato natural products and the potential disadvantages of producting complex mixtures of products and introducing pyrogenic macromolecular contaninants. Carbon dioxide and ammia are precursors to complex molecules In nature and therefore enzymes which catalyze their conversion into organic molecules are well characterized. For this reason the readily avallable short lived precuisors ${ }^{11} \mathrm{CO}_{2}$ and $13 \mathrm{NH}_{3}$ have served as precursors in a number of blosynthetic approaches to ${ }^{11} \mathrm{C}$ and $13_{\mathrm{N}}$-labeled organic molecules. In addition, $E^{11}$ CHO has been used as a precursor in the enzymatic synthesis of $11_{C}$-thywidine (100). Although $13_{\mathrm{N}}$-labeled nitrate and molecular nitrogen have been used to study the nitrogen assimilation and metabolism in bacteria (393-39?), tiney have not actually been used with blosynthesis of $13 \mathrm{~N}$-labeled molecules as a goal. Tables 3,4 , and 5 provide a listing of ${ }^{11_{C}}$ and $18_{\mathrm{F}-}$ and

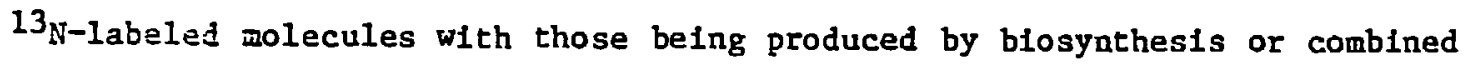
chemical and biosynthesis recelving special notation (*).

The utility of blosynthetic approaches depends on the biosynthetic system enployed. This determines whether a single product or a multiplicity of products are produced and also determines the ease and speed with which single, pure product, free from macromolecular contamination, can be 1solated. The complexity of the reaction mixture is especially critical with $13 \mathrm{~N}$ because of 1 ts short half-life.

Thus far some of the blosynthetic approaches used with short-lived auclides include photosynthetic systems using plant materlal, purified and 
partially purified enzymes Including immobilized enzymes, and rat liver microsomes. These systems have been used to synthesize molecules and, In some cases, to resolve optical isomers by reacting selectively with one enantiomer. In sone cases, a combination of synthetlc and biosynthetic schemes have been used to synthesize the desired radiotracer.

The photosynthetic production of $11_{\mathrm{C}-g l u c o s e}$ is a modification of a method used for preparing ${ }^{14} \mathrm{C}$-glucose (398) and was first reported in 1971 (267-268). The approach 1nvolves the recirculation of ${ }^{11} \mathrm{CO}_{2}$ aroind fresh (11ght starved) Swiss Chard leaves in the presence of Incandescent 11ght. The crude unhydrolyzed reaction mixture contains $11_{C}$-sucrose and ${ }^{11_{C}}$-sugar phosphates. After hydrolysis, the labeled free rugars gluccae and fructose and sugar phosphates are present.

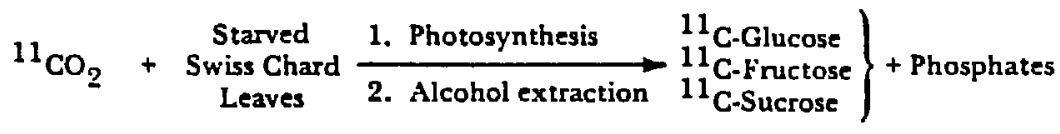

$$
\begin{aligned}
& \frac{\text { 1. } \mathrm{H}^{+}}{2 . \text { Neutralize }}{ }^{11} \text { C-Glucose } \stackrel{\text { HPLC }}{\longrightarrow}{ }^{11} \text { C-Glucose }
\end{aligned}
$$

The separation of sugar phosphates from ${ }^{11_{C}} \mathrm{glucose}$ and fructose is accomplishad by ion exchange chromatography after which $11_{C}$-glucose is separated from IIC-fructose by high pressure Ilquid chromatography (269-270). Since intact plants are used in this synthesis, a multiplicity of products are produced necessitating an Involved workup and puriflcation scheme. Nonetheless, the sinplicity of the photosynthetic system makes this a very attractive synthesis and the separation of pure ${ }^{1 l_{C}}$-labeled glucose from this complex reaction mixture of labeled compounds and plant materials in an overall time of 75 minutes is worthy of comment. More recently this general method has been modified to use the green alga Scenedesmus obtusiusculus Chod as the plant waterlal and $\mathrm{B}^{11} \mathrm{CO}_{3}{ }^{-}$as the feed material (271). Since the $\mathrm{H}^{11} \mathrm{CO}_{3}-$ can be easily shielded and transported to a chemistry facility, this method offers an alternative when the photosynthesis cannot be carried out adjacent to the cyciotron. ${ }^{11} \mathrm{C}$-Glucose is of special interest as a radiotracer for quantitating brain glucose metabolism and the mathematical models for extracting reglonal metabolic rates from emission tomographlc data have been developed ( 3 ).

The enzynatic synthesis of ${ }^{11} \mathrm{C}$-amino acids from ${ }^{11} \mathrm{CO}_{2}$ has been applied to L-aspartic acid using a crude extract of chicken liver acetone powder with the conditions for the reaction belng optimized with carbon-14 (199). A 
refinement of this approach to $\mathrm{L}-[4-14 \mathrm{C}]$ aspartic acid has been recently reported using immobilized phosphoenolpyruvate (PEP) carboxylase to catalyze

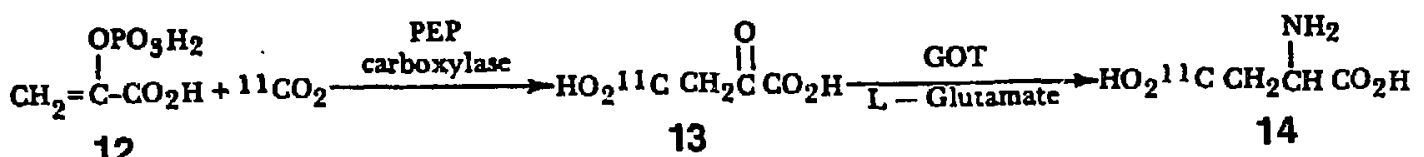

12

13

14

the reaction between phosphoenolpyruvic acid $\underline{12}$ and $11 \mathrm{CO}_{2}$ to form [4-11C]-oxaloacetate 13 followed by Immobilized glutamate/oxaloacetic acid transaminase (GOT) to transform ${ }^{11} \mathrm{C}$-oxaloacetic acid into aspartic acid 14 . The use of immoblized enzymes allowed the production of pharmaceutical quality L-aspartic acid In 15-25 minutes after ${ }^{11} \mathrm{CO}_{2}$ production with sufficlent quantities belng produced to allow its evaluation as a tracer for local myocardial metabolism (200).

A two-step enzymatic synthesis of ${ }^{11} \mathrm{C}-\mathrm{L}$-lactic acid has been developed and consists of 1 ) production of $\mathrm{C}-11$ pyruvate from ${ }^{11} \mathrm{CO}_{2}$ and acetyl $\mathrm{CoA}$ in the presence of an enzyme extracted from Clostridiun acidi urict and 2) conversion of $\mathrm{C}-11$ pyruvate to ${ }^{11} \mathrm{C}$-lactic acid by lactic dehydrogenase in a

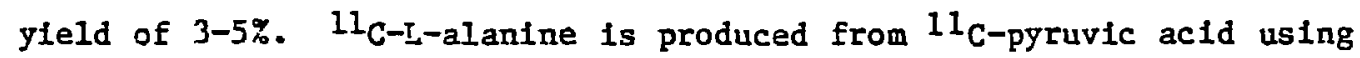
glutamic-pyrurtc transaminase (181-182).

Isolated enzynes have been used to synthesize L-amino acids using

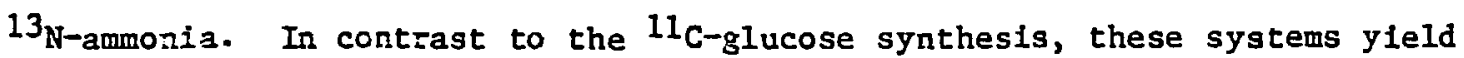

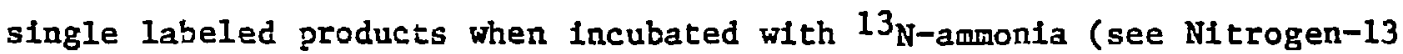
section). Sequential enzymatic syntheses have also been used. Briefly, the procedure lavolves incubation followed by purification by ion exchange chromatography, which gives a radiochemically pure product frequently contaminatei by potentlally pyrogentc macromolecular materials. The use of Immoblifzed enzymes, however, ylelds pharmaceutical quality materlals. Although many of the enzymes which have been used are obtained from commerclal sources 1 a some cases, enzyme isolation as well as inmobilization may be necessary.

Another attractive tactic comblnes synthetic and blosynthetic techniques. For example, the conversion of ${ }^{11} \mathrm{C}-a$ anine (15) to 3-11-C-lactic (1E) has been accomplished and involves the synthesis of $11_{C-a l a n i n e}$ by a

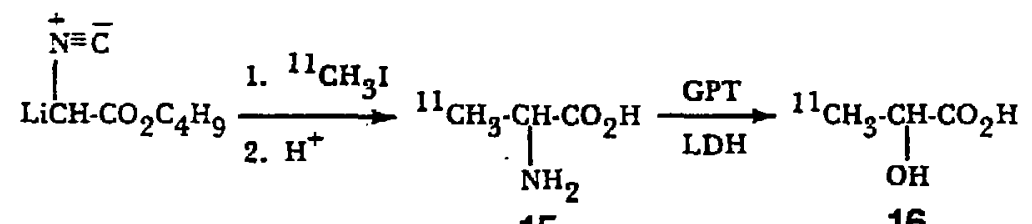

$15 \quad 16$

synthetic route followed by the enzymatic (glutamate pyruvate transaminase, GTP) conversion to lactic acid in the presence of a-ketoglutarate and lactic 
dehydrogenase ( $\mathrm{LDH}$ ). The enzymatic synthesis, uses only the $\mathrm{L}$-isomer of alanine, thereby reducing the radiochenfal yleld (183). Asymnetric Induction has stnce been used to enrich the L-alanine in the mixture (178).

In another similar combination of techniques, enzymes have been used to resolve $D, L$-mixtures of labeled amino acids. This has been applied to
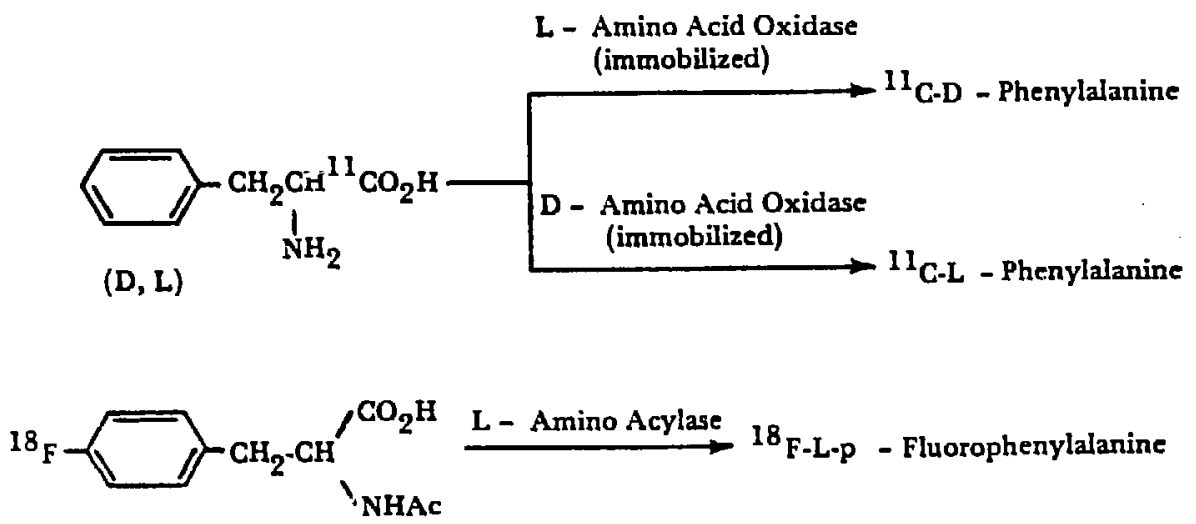

$(\mathrm{D}, \mathrm{L})$

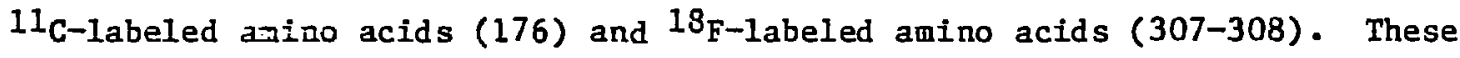
enzymatic resolution methods along with the chromatographic resolution of amino actds $(195,198)$ offer the posslbllity of dolng studies on amino acld metabolisu using the physiologically active L-isomer thus reducing background activity as well as the radiation dose resulting from the D-isomer.

Another approach which has only been explored briefly, but which could probably be exploited to a greater extent is the use of mitochondria to carry out synthetic transformations. In the one example reported ${ }^{1{ }^{1} \mathrm{C}-\mathrm{h} \text { - } p \text { puric acid }}$ was prepazed Erom 11-C-benzoic acid and glycine using rat liver mitochondria (221).

These examples were chosen to 1llustrate the potential advantages and problems essoclated with bissynthesis. The application of a combination of synthetic and blosynthetic techniques allows maximum flexibility and provides an attractive alternative to the use of a single approach. Advances in enzyme technologg as well as chromatographic techniques can be expected to contribute significantly to future developments in the biosynthetic approach to short-lived radlotracers.

\section{Radiotracer Puriflcation and Quality Control}

Assuming the absence of radionuclidic impurities, there are three requirements which radiotracers must meet. The first two are that the product 
be chemically and radiochemically pure and the third is that the material be sterile and pyrogen free if it is to be used in human studies. These standards must be met and verified while working within a restricted time scale.

The synthesis of short-lived positron emitting radiotracers generally gives a crude reaction mixture containing the desired labeled product, labeled and unlabeled side products, and excess reagents and substrates. Frequently It is possible to purify an acidic or basic compound by extraction as exemplified by the synthesis of ${ }^{11_{C}}$-alkylamines $(41,255)$ and ${ }^{1 l_{C}}$-palmitlc acid (211). When more complex separations are encountered, however, other strategles must be used. The choice of separation method, of course, depends on the composition of the reaction mixture.

The use of chromatographic materials of small particle size in conjunction with high, and medium pressure Ilquia chromatography (HPLC and MPLC) has revolutionized the separation of compounds which differ only slightly in their structures. An essential feature of these separations is their speed and high resolution. This technology has been applied to normal and reverse phase as well as Ion exchange separations and has wide application In the purification and analysis of short-lived radiotracers.

A revian covering the literature on fon exchange and liquid chromatography for 1978 and 1979 provides an excellent survey of recent developnents (399) and a guide to books and review articles appearing during this tine perfod. In addition the Journal of Chronatography provides a yearly bibllography on gas chromatography, liquid chromatography and thin layer chromatography (400). An excellent text on the fundamentals and applications of chromatography is also recommended (401).

Ion exihange chromatography is frequently effective in the purification of amphoteric, acldic and basic compounds as well as sugars. It can be used to remove detal ions from reaction mixtures as in the synthesis of 11 C-2-deoxysiucose, and to simply imobilize the desired product while undesired components of the reaction mixture are removed as in the synthesis of ${ }^{11}$ C-labeled catecholamines (251-253). The above two applications simply involva rapid filtration of the crude reaction mixture through the appropriate resin rather than effecting a separation through the amplification of subtle differences in acidity or basicity. In contrast, the separation of sugars having only slight structural differences is rapidly accomplished by the use of micro-particulate cation exchange resins and HPLC examples being the

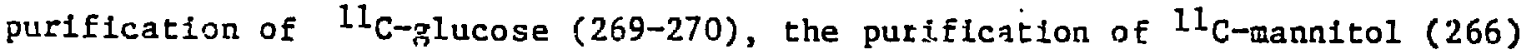
produced by photosynthesis, or the chronatography of $\left({ }^{18} \mathrm{~F}\right)-2$-deoxy-2fluoro-D-glucose (402). 
Normal phase chromatography over silica gel is a classical separation method which has recently been fmproved through the use of small particle size silica gel and HPLC and MPLC techniques. This has allowed rapld separations to be effected. The HPLC technique usually involves the frequent monitoring of the resolving power of the colunn. This also applies to reverse phase chromatography and procedures for regenerating these expensive columns which have lost their resolving power can often be obtained from the manufacturer. Frequently, the reversal of the elution patterns for compounds on a reverse phase compared to a normal phase column can be used to advantage. For example, it is desirable, in separating two compounds with only slightly different retention times, to have the desired product elute first to avoid contamination by tailing. The use of HPLC (403) as well as incorporation of HPLC into an autonated synthesis system has been reported for the routine and frequent synthesis ${ }^{11} \mathrm{C}$-labeled Imipramine at high activity levels and an automated remote injection system has also been described $(185,230,403-405)$. Here revarse phese chromatography is used to effect the rapid separation of ${ }^{11}$ C-labeled inipzanlne from desuethylimipramine, the starting material.

An option of HPLC for normal phase separations requiring medium resolution ( $A R_{F}>0.15$ ) is flash chromatography. Flash chromatography is an afr pressure driven hybrid of medium pressure and short column chromatography (406). The advantage of this method is not only its simplicity and reliability, but also that the solvent system used to separate a given mixture on Merck tlc plates (No. 5775) can be used with the silica gel columns (Merck No. 9385) with similar results. This permits a rapid exploration and optinization of column confitions. The use of fresh silica get for each separation ensures the reproducibility of the separation. The average separation requizes ifve minutes and when elution volumes are determined in advance a siaple colum design involving two fractions can be used (Figure 2). This technfque is routinely and reliably used fin our labroatory in the synthesis of $18_{\mathrm{F}-2-\text { deoxy-2- }}$ fluoro-D-glucose (349), 1IC-2-deoxy-Dglucose (277) and ${ }^{1}$ C-spiroperidoi 304). Figure 2 aiso sinows the separations achieved by compering radio thin layer chromatograms of the crude reaction mixture (a) forecut (b) and product fractions (c) after separation. Another alternative to common chromatographic techniques is vacuum liquld chromatography which also features good resolution in short times (407).
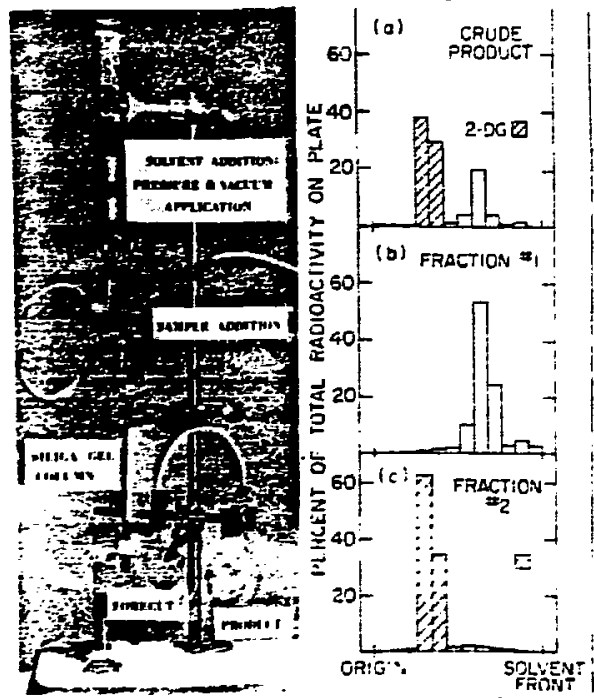

Fig. 2 Purification of ${ }^{11} \mathrm{C}-2 \mathrm{DG}$ by flash chromatography 
Thin layer chromatography (TLC), HPLC, and gas liquid chromatography (GLC) are commonly used methods for determining radiochemical purity of short lived radiotracers. The adequacy of an analytical method depends on the chromatographic similarities of impurities. Guidance on the selection of adsorbants, solvents and detection systems can often be obtained by consulting compilations of chromatographic data in various sources $(399-400,408)$. For most routine applications TLC is a simple rapid method for determining radiochemical purity especially if the product is chromatographed in a number of solvent systems. The use of plastic back tlc sheets allows the simple accurate determination of the distribution of radioactivity by cutting the sheets into strips and counting the strips in an automatic or manual well counter. Alternatively TLC scanners or autoradiography can be used (408a). Many TLC systems require only 5-10 minutes for development and are therefore sultable for use with short half-life tracers. Frequently the addition of inactive carrier compound to a sample of the radioactive compound is required for the analysis since the mass of compound produced in a high specific activity or no carrier added synthesis is below detectable limits. It is not unusual to encounter TLC artifacts with acidic or basic compounds, especially when suall amounts of acid or base are present in the spotting medium and one should $b \geq$ arvare of this as well as radiochemical fmpurfties as a possible cause for unusual activity distribution (409-411). Applications laboratories assoclated with comercial producers of liquid chromatography equipment and columns are a frequently good source of Information on the choice of HPLC colums and solvent systems for particular applications.

Gas Iiquid chromatography is also a useful reliable method of determining radiocherical and chemical purity. Its use frequently requires the derfvatization of the product to increase its volatility and procedures for fording Cerivatives are well established. GLC also is a powerful tool in the determination of target gas composition, an application which may be necessary for developgent work and in tracing the cause of difficulties encountered in precursor production. An automatic gas liquid chromatogiaphy apparatus for the analys is of organic compounds labeled with short-lived radiolsotopes has been described ( $411 a$ and references therefn).

The production of a sterlle, pyrogen free radlotracer for hunan use requires the establishment of a procedure which has been proven to yield a pharmaceutical quality product, and then strictly adhering to the protocol. After-the-fact testing for sterility and apyrogenicity is carrled out at Erequent intervals. 
CARBON-II

Carbon-II as a Label for Radiotracers

Carbon and hydrogen are the most ubiquitous of elements present in the biomolecules of life. Carbon, as is the case with hydrogen, exists in both stable and radioactive forms but only carbon has radionuclides which are positron enitters and which can be used s provide body penetrating radiation for monitoring dynamic processes in animals and humans. The most well known of carbon tracers are carbon-14, a long lived B-emitter and carbon-13, a stable isotope. Other radloactlve forms of carbon include carbon 9 $\left(t_{1 / 2} 0.13 s\right)$ carbon-10 $\left(t_{1 / 2} 19.4 s\right)$ and carbon-11 $\left(t_{1 / 2} 20.3 \mathrm{~m}\right)$ but, of these, only carbon-11 has been used extensively in biological and medical research. It is a positron emftter with a small ( $\sim 0.19 \%)$ electron capture component and decays to a stable isotope, boron-11. It is quite possibly the first positron einitter that was used in blochemical and medical research $(217,412)$. Because of the short half life its popularity dwindled as a tracer for chemical enci many biochemical studies when carbon-14 became avallable in the late 1940's (217). Nevertheless its unique physical properties, particularly the body penetrating photons resulting from positron annihilation in the host have regenerated increasing active Interest in its use in the past ten years. In adilition, its 20.4 minute half-11fe is particularly sulted for serial studies of the dynamics of $11_{C}$-labeled radiotracers in a single human or animal subjest at short time intervals.

The chenlal properties of carbon-11 are indistingulshable from those of carbon-12 and thus it is the ideal label for biomolecules and drugs where metabolism or catabolism does not destroy its effectiveness as a tracer. The maximum kiretic isotope effect which can result from cleavage of a carbon-11 to carbon-12 bond is of the order of $6-8 \%$. This can usually be neglected since its use as a tracer in-vivo rareiy reflects this difference and carbon-carbon boad breakage in a blomechanistically significant step is

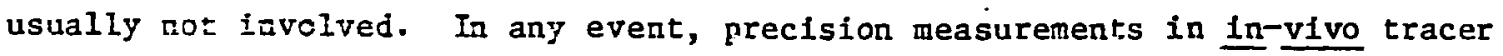
applications are such that an isotope effect of $1-4 \%$ (the most commonly observed range) would not be detected. However, if degradative procedures are used to verify label positions then the isotope effect must be taken into account if precise label concentrations are to be determined. Fortunately, an abundant theoratical and experimental literature exists for carbon-14 and carbon-13 (413) and this precise estimates for carbon-11 effects can be addressed.

secause of the short half life of carbon-11, production of large quantities of the fsotope is mandatory if the final product is to be made 
available in sufficient quantity for biological and medical studies which require more than a few minutes for data acquisition. One must draw a distinction at this point between tracers such as $11 \mathrm{CO}$ and $11 \mathrm{CO}_{2}$ which can be made avallable at $E O B$ in near quantitative yield and tracers requiring more extensive synthetic work with concomitant decay during synthesis non-quantitative chemical yields and losses during purification. Fortunately, carbon-11 is one of the most easily prepared radionuclides with a variety of nuclear reactions being avallable utilizing targets that are not isotople with the product. Although choice of production methods do depend on available charged particles e.g. protons and/or deuterons and whether or not external beams are available, for the great majority of applications the simple and rellable nitrogen gas target utilizing the ${ }^{14} \mathrm{~N}(\mathrm{p} \alpha)^{11} \mathrm{C}$ reaction is in use in most laboratorles doing extensive synthetic work (89). A useful alternative

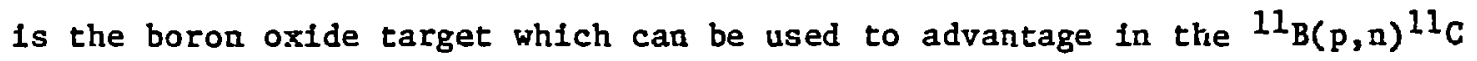
reaction or the $10_{B(d, n)}{ }^{11} \mathrm{C}$ reactions depending on particle avallability (see 164 and references therein). Although the use of the enriched boron isotope can enhance the carbon-11 yleld, acceptable quantities can be obtained from the natural abundance compound. Targetry for the boron system is somewhat more cumbersome and target reprocessing or "throw-away" targets are necessary.

Simple Carbon-11 Compounds and Other Precursors Used as Radiotracers (see Table 2)

Syathesis of organic compounds contalning carbon-11 has as its major constraint the time available between acquisition of the radionuclide and delivery of the compound to the user. While this may seem obvious, the literature contains synthetic procedures lnvolving carbon-11 which are in no sense practical with regard to biological research to say nothing of application in humans. Problems Involving loss of the radionuclide and/or interrediate due to surface to volume effects and adsorption properties of vessels, substrates used for purification etc. are very much more prominent in carbon-11 syntheses than in carbon-14 syntheses. This is not surprising when one considers the fact that a millicurie of carbon-14 contains $9.59 \times 10^{18}$ atons, equal to $a$ welght of 0.22 milligrams, whereas a millicurie of carbon-11 contains $6.53 \times 10^{10}$ atoms equal to a weight of 1.5 picograms. Another problem which is pecullar to syntheses with carbon, very much more so than with other elements because of chemical factors and the fact that carbon is ubiquitous in nature, is the danger of dilution with carbon-12 resulting in reduction of specific activity below that of the spectfic activity of the starting precursor. The preparation of a truily carrier free compound (remembering that in this case of carbon one applies the term carrier free to 
a specific carbon position in the molecule) is highly improbable. Nevertheless dilutions in the range of 100 times greater than $C F$ should be possible as the technology of carbon-1l precursor production advances. The possibility of labeling more than one position in a single molecule of more than two or three carbon atoms as has been accomplished with carbon-14 substitution is extremely remote with carbon-11. Here again the level of sophistication reached in in-vivo experiments with carbon-11 do not at present demand attempts to prepare such compounds. At least one advantage presents itself in carbon-1l synthesis. Appreciable self radiolysis in preparation are precluded even at the $100 \mathrm{mCl}$ level when one considers the very small amounts involved and the radial range of the positron (414) (see Table 1).

There are only three widely used simple precursors for synthesis with carbon-11, ${ }^{11} \mathrm{CO}_{2},{ }^{11} \mathrm{CN}$, and $\mathrm{B}^{11} \mathrm{CHO}$. However, this does not mean that, as the field grows, greater use will not be made of some of the other readily avaflable simple compounds. This should be particularly true of carbonylation reactions utilizing ${ }^{11} \mathrm{CO}$.

The preparation of ${ }^{11} \mathrm{CO}_{2}$ in up to Curle quantities from a nitrogen gas target is simple and straightforward. The nitrogen gas target must contain a few ppm of oxygen but that is usually the case for most conmerctal sources of purifled nitrogen gas. The tank gas should, however, always be analyzed by gas chromatography before being attached to the production Ine to be sure that carbon containing impurities are absent or present at acceptable levels. The presence of inpurities such as $\mathrm{CO}, \mathrm{CO}_{2}, \mathrm{CH}_{4}$ etc. will serve to materially reduce the specific activity of the ${ }^{11} \mathrm{CO}_{2}$ produced. Levels of these impurtities can be reduced cryogenically and/or by using suitable adsorbents. Suitable simple target systems can be found in the literature (89). Preparation $\mathrm{f} z \mathrm{O}$. $\mathrm{B}_{2} \mathrm{O}_{3}$ poses similar problems in that the $\mathrm{B}_{2} \mathrm{O}_{3}$ can contain carbon impurities. Eowever, the sweep gas, usually He, can also Introduce carbon impuritias and this should be kept in mind during production. The major product from these targets is ${ }^{11} \mathrm{CO}_{2}$. If the ${ }^{11} \mathrm{CO}$ contaminant is of no consequence in the synthesis, the gas mixture can be used directly in the first step of spnthesis. Eowever, if it is necessary to optimize the ${ }^{11} \mathrm{CO}_{2}$ yield the gas can be passed over Clo to insure near quantitative conversion to $11 \mathrm{CO}_{2}$. Care Iust again be taken not to introduce trace quantities of carbon at this point. Carbon monoxide can also be produced directly by increasing the oxygen content of the target gas to a few percent. However, at high production levels the oxtdes of nitrogen produced in the target system make the isolation of the ${ }^{11_{C}} \mathrm{Co}$ more difficult. It is more generally useful to pass the effluent purffled nitrogen target gas over $\mathrm{CuO}$ for ${ }^{11} \mathrm{CO}_{2}$ production and over metallic $z$ lnc for ${ }^{11} \mathrm{CO}$ production. This adds a few minutes to the 
production of these two precursors after EOB. The complex chenistry occurring in the target should be kept in taind since the yields are a function of both dose and dose rate (415).

At the present time remote systems which deliver ${ }^{11} \mathrm{CO}$ and ${ }^{11} \mathrm{CO}_{2}$ reliably can be purchased fron cyclotron manufacturers but as yet no simplified computer controlled ( $1 . e$. truly automatic) system is comercially available. In any event, construction of a reliable ${ }^{1 l_{C O}}$ and ${ }^{1 l_{C O}}$ production system is well within the capability of any chemistry facility associated with a cyclotron complex.

The preparation of $\mathrm{B}^{11} \mathrm{CN}$ and $\mathrm{B}^{11} \mathrm{CHO}$ are most effectively carried out by on-1ine systems connected to the target systems. While direct production of

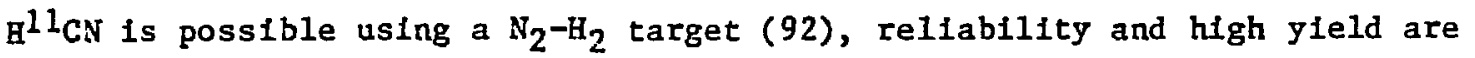
best served by using a combination of target chemistry and subsequent chemical processing $(89,415)$. The $\mathrm{N}_{2}-\mathrm{H}_{2}$ target is run at high beam current so that the $H^{11} \mathrm{CN}$ initially produced is radiolytically reduced to ${ }^{11} \mathrm{CH}_{4}$ in situ. Small amounts of $\mathrm{NH}_{3}$ are produced in the target gas mixture concomitantly with the ${ }^{11} \mathrm{CH}_{4}$ and this mixture of ${ }^{11} \mathrm{CH}_{4}$ and $\mathrm{NH}_{3}$ is passed over $\mathrm{Pt}$ wool at $1000^{\circ} \mathrm{C}$ converting $i t$ to $\mathrm{H}^{11} \mathrm{CN}$ which can then be used for synthetic purposes. It

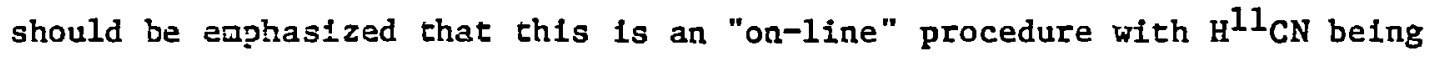
avaliabie for organic synthes ls at the end of bombardment with no manipulation required.

Procedures for production of $\mathrm{H}^{11}$ CHO are less satisfactory in that they must be performed after cyclotron bombardment, are time consuming and are not

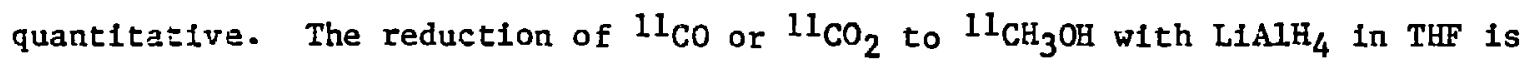
followed by catalytic oxidation using ferric molybdenum oxide (100) or silver wool $(98,101)$ Nevertheless, millicurle quantities of $\mathrm{H}^{11} \mathrm{CHO}$ in 10 to $20 \mathrm{~min}$ EOB are reajily obtained.

In addition to $\mathrm{H}^{11} \mathrm{CHO},{ }^{11} \mathrm{CH}_{3} \mathrm{I}$ which 1 also of considerable utility can be obtained via rapid synthetic procedures (97-99). These methods all depend on the conversion of ${ }^{11} \mathrm{CH}_{3}$ OH prepared in the conventional manner, to ${ }^{11} \mathrm{CH}_{3} \mathrm{I}$ usually uslig hydrolodic acld although other lodinating agents have been reported. Recently the production of ${ }^{11} \mathrm{CH}_{3} \mathrm{I}$ by direct recoll synthesis in a $\mathrm{X}_{2}$ - $\mathrm{HI}$ flow target syster was reported (96).

A number of other one and two carbon intermedlates for synthesis such as cyanate, phosgene, acetylene, 1 or 2 labeled ethanol, acetic actd, and acetone have been described (see Tables 2,3).

While the appearance of novel or completely new synthetic procedures is unlikely in the development of labeling methods with carbon-1l, the adaptation and modification of known procedures to allow rapld preparation of needed 
compounds at high specific activity presents a challenge to the synthetic organic chemist as great as can be found in the syntheses of new and ever more complex organic structures. The challenge is clearly apparent in the "rule of thumb" for organic synthesis with short lived radionuclide in that the time for preparation from EOB to EOS should not exceed $3 \times t_{1 / 2}$ for the element in question.

Major advances in years to come will also depend on true automation of

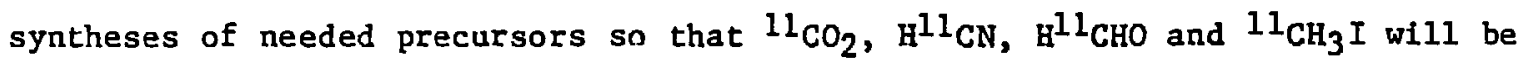
available as usable reagents at ECil or near EOB without operator intervention. Their ready availability as reagents will greatly facilitate the synthetic work which will follow.

\section{Synthesis with Carbon-11 Labeled Precursors}

The many different compounds which can be produced using carbon-11 labeled precursors are apparent from the listings in Table 3 which is arranged according to compound type and includes labeled precursor, labeling reagent and reference. The introduction of carbon-1l in a complex molecule in the great majority of cases depends on the formation of a new carbon-carbon or carbon nitrogen bond. In that the Iimitations of time are met, reactions which involve powerful nucleophiles such as compounds containing carbon to metal bonds or substitution reactions in which solvent conditions are chosen to enhance tite nucleophilic character of the labeling anion are usually chosen. Condensation reactions have been exploited to a lesser degree because of their generally slower reaction velocities.

One of the most facile reactions for carbon carbon-bond formation is the carboxylation of a Grignard reagent or other organometallic reagents such as

$$
\mathrm{RHgX}^{11} \mathrm{CO}_{2} \rightarrow \mathrm{R}^{11} \mathrm{CO}_{2} \mathrm{MgX} \rightarrow \mathrm{R}^{11} \mathrm{CO}_{2} \mathrm{H}
$$

organolithius reagents. For example $\alpha$-lithioisonitriles have been carboxylated to produce ${ }^{1} I_{C}-1$ abeled amino acids such as $\alpha$-phenylglycine, $\alpha$-phenylalanine and L-DOPA (see Table 3 for examples) 


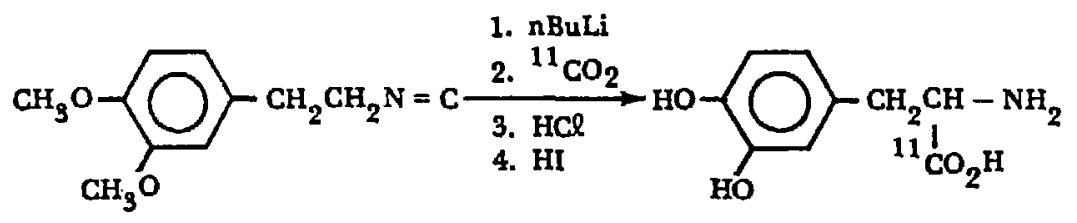

One of the earliest synthesis with carbon-ll was the preparation of 1-11-C-acetic acid from $\mathrm{CH}_{3} \mathrm{NgI}$ and ${ }^{11} \mathrm{CO}_{2}$ (217). The carboxylation of a Grignard reagent has been extensively used (see Table 3 for examples). There are two approaches. One can condense the ${ }^{11} \mathrm{CO}_{2}$ into reaction vessel and subsequently add the Grignard or other organometallic reagent. The organouetallic reagent can be used most efficiently in this way and solvent volumes can be kept to a minimum. Alternatively the ${ }^{11} \mathrm{CO}_{2}$ can be swept through the soiution organometallic reagent slowly over a period of 15-30 minutes. Subsequent work-up follows normal synthetic procedures: This reaction lends itself readily to remote operation and should be simple to automate. Great care must, however, be taken in carrying out this type of reaction 1 if the spacific activity of the product is to be kept high. Not only will the ${ }^{11} \mathrm{CO}_{2}$ be diluted with some amount of carrier depending on the method of production and transport but the strongly basic substrate solution will actively react with any contaninant source of ${ }^{12} \mathrm{CO}_{2}$ in the systen. Grignard machines for this purpose should be set up with a minimum number of joints and transfer lines. Solvents should be degassed and reagents kept free of exposure to eir or other sources of ${ }^{12} \mathrm{CO}_{2}$. Iuert gas for transfer or as a blanket for the reaction mixture should be dry and scrubbed cryogenically and chemically to remove all trace of ${ }^{12} \mathrm{CO}_{2}$. Yields are frequently very high and a carboxylic acid can be prepared in under 40 minutes from EOB. Synthesis time can be materially shortened by using an on line flow system and trapping the ${ }^{11} \mathrm{CO}_{2}$ as it is being produced. Hundreds of millicuries of carboxyl labeled acids can be produced in this way.

Carbon-11 labeled hydrogen cyanide is of considerable value as a labeled precursor for two reasons. Firstly, it is avallable at end of cyclotron bombardment with no operator intervention (89). Secondly, it is readily used in displacanent and addition zeactions which proceed rapidly to produce $11_{C}$-labeled nitriles or cyanohydrins. These are valuable intermediates in the synthesis of a wide variety of $11_{C}$-labeled compounds which are of use in radiotracer research. These reactions are shown in generalized form below. 


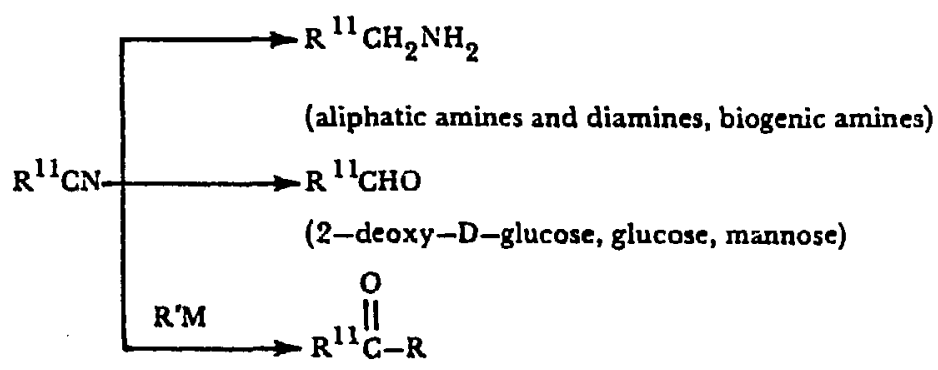

(spiroperidol)

The use of $\mathrm{H}^{11} \mathrm{CN}$ in ${ }^{11} \mathrm{C}$-dopamine synthesis involves the preparation of the cyanohydrin which is prepared from the bisulfite addition product of 3,4-dihydroxybenzaldehyde is readily reduced to $1^{-1 l_{C}}$-dopamine hydrochloride using $\mathrm{Pd} / \mathrm{C}$ and $\mathrm{F}_{2}$ in actdic solution (251). Alternatively the cyanohydrin can be reduced with $\mathrm{BH}_{3}$ and then purifled to yleld $1-11_{\mathrm{C}}$-noreplnephrine hydrochloride (253). Alkyl nitriles are readily prepared by ${ }^{11} \mathrm{CN}^{-}$ displacenent on an alkyl hallde in DMSO of DMF (for examples see Table 3, [cyano-11 C]nitriles). These can be rapldly reduced directly to the amine (with $\mathrm{LiAlF}_{4}$ or other suitable reducing agent). Sugars and deoxysugars (Table 3) Iabeled at $C-1$ also readily accessible by extension of chain length with ${ }^{11} \mathrm{CN}_{\mathrm{N}}$ isplacenent on carbon attached to a sultable leaving group, for example tiffiate, mesylate or lodide. Judiclous choice of leaving group can be critical. For example, a blocked arabinitol triflate is converted to the nitrile oaly after several days at $25^{\circ}$ in DMF as solvent whereas conversion of the same arabicitol triflate to the nitrile takes place in a few minutes at $25^{\circ}$ in DMF (277) (see Substrate, Structure, Reducing Agents, Protective Groups and Solvents;.

The preparation of a number of amino acids labeled in the carboxyl group can be accomplished by using a modification of the Bucherer-Strecker synthesis (see 175 and examples in Table 3). The appropriate aldehyde or ketone is zixed with $\left(\mathrm{NH}_{4}\right)_{2} \mathrm{CO}_{3}, \mathrm{NH}_{4} \mathrm{Cl}$, and aqueous $\mathrm{Na}{ }^{11} \mathrm{CN}$ and heated to
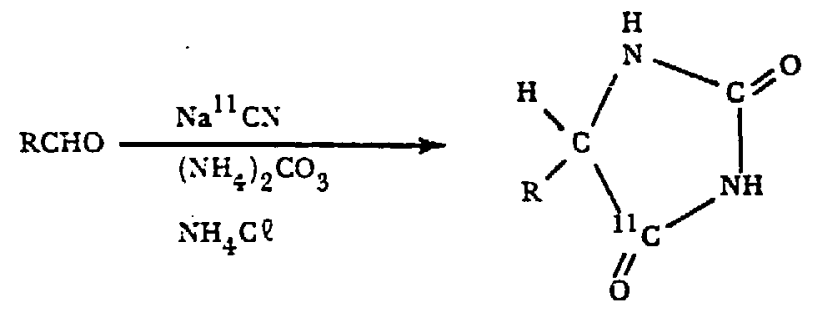

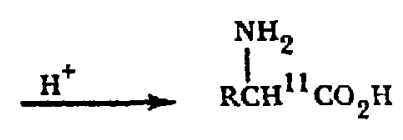

between 210 and $240^{\circ}$ in a sealed metal reaction vessel for 5-10 minutes. The vessel is opened, NaOH solution added, and resealed and heated for another 10 minutes to accomplish hydrolysis of the intermediate hydantoin. The resulting 
${ }^{11} \mathrm{C}$-labeled $\mathrm{D}, \mathrm{L}$-amino acid mixture can be resolved to give the natural L-amino acid using enzymatic techniques (176), HPLC with chiral column materials (195) or selective binding to albumin (198).

Introduction of a methyl group in such diverse compounds as proteins, antidepressants and naturally occurring polyamines e.g. putrescine and spermine has been accomplished by reductive formylation. Formic acid

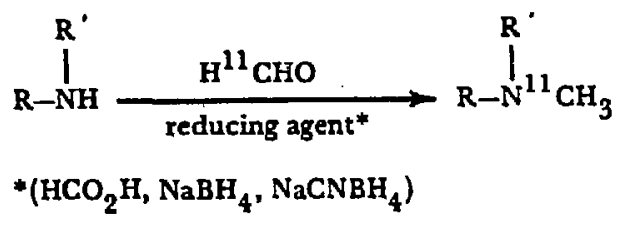

(Eschweiler-Clarke reaction), sodium borohydride, sodium cyanoborohydride or other suitable reducing agents can se used. Both albumin and fibrinogen have been conventently labeled by combining a buffered solution of the protein with a basic solition containing the $\mathrm{B}^{11} \mathrm{CHO}$, equilibrating for a few minutes and then adding a basic and buffered solution of the sodium borohydride (238). The methyiated protein (1.e. $\mathrm{RNH}^{11} \mathrm{CH}_{3}$ ) is then isolated and purffied. Methylation of desmethylimipramine is accomplished by first forming the imine in acid sclution containing ${ }^{11}$ CHO folowed by reduction of the imine with $\mathrm{NaCNBH}_{3}$. In this way chlorpromazine, imipramine and nicotine are readily labeled (see Table 3 ).

Methylation with ${ }^{11} \mathrm{C}$-methyl iodide is also conveniently carried out. There is frequently a choice to be made between reductive formylation and displacenent on methyl iodide. Compare, for exanple, the preparation of [N-methy1-11 C] morphine with $\mathrm{CH}_{3} \mathrm{I}$ (226) and $\mathrm{H}^{11} \mathrm{CHO}$ (227)

Carbon-11 labeled L-methiontne 17 has been prepared by allowing L-hodocysteis tilolactone 18 to react with ${ }^{11} \mathrm{CH}_{3} \mathrm{I}$ in basic acetone containing solution. The ylelds are high and the purffled product is

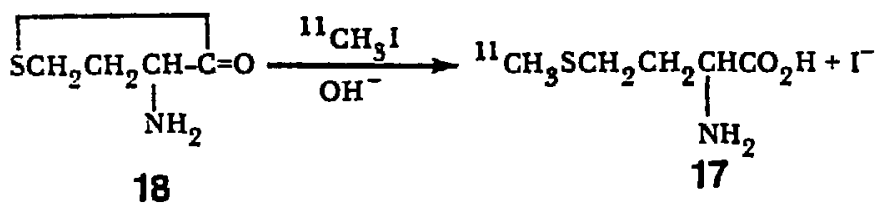

obtained in $30 \mathrm{~min}$ from EOB (185). Other routes to ${ }^{11} \mathrm{C}$-nethionine appear in Table 3 as well as numerous other examples of methylation with ${ }^{11} \mathrm{CH}_{3} \mathrm{I}$. 
A potentially useful reaction for preparing carbon-11 labeled compounds is carbonylation by insertion of ${ }^{11} \mathrm{CO}$ into a carbon-boron bond. For example [1-11 $\mathrm{C}$ ] octanal 19 was prepared by allowing ${ }^{11_{\mathrm{CO}}}$ to react with n-hepty1-9-borabicyclo-[3.3.1]nonane and $\left(\mathrm{CH}_{3} \mathrm{O}\right)_{3}$ LiAlH. The adduct was then oxidatively hydrolyzed (291). Reactions of this type (for versatility see hydrolysis

$$
\text { B-heptyl-9-BBN + }\left(\mathrm{CH}_{3} \mathrm{O}\right)_{3} \mathrm{HLiAl}+{ }^{11} \mathrm{CO} \frac{(\mathrm{pH}=7)}{\mathrm{H}_{2} \mathrm{O}_{2}(30 \%)} \mathrm{C}_{7} \mathrm{H}_{15}{ }_{19}^{11} \mathrm{CHO}
$$

416-418) can make use of the readily available precursor ${ }^{11} \mathrm{CO}$ and simplify access to carbon-11 labeled compounds such as aldehydes.

While the above examples serve to provide a measure of the synthetic versatility of the most easily avallable precursors it is clear that many other types of compounds are accessible from these precursors as from some of the less readily avaflable one two and three carbon precurgors listed above and in Tajle 2.

Conclusion

Many classes of compounds can be prepared from carbon-11 labeled precursors. Sone of these syntheses are simple and straightforward such as carbonation of a Grignard and some very much more complex such as amino acid syntheses, deuroleptic syntheses and sugar syntheses. It is important to refterate one of the peculiarities of synthesis with carbon-11 and that is the problem of carboc-12 carrier. Wherever posstble a direct measure of specific activity of the precursor or compound should be made. For example the Nash assay or dezivatization procedure can be used for formaldehyde (419). Extremel; sensitive methods (to within a factor of $10^{3}$ of carrier free) exist for the assig of cyanide (420-421). Compound assay in some spectal cases is also possible via radio-receptor procedures (422). Unfortunately, no reliable and staple pethod has yet been devised for assay of dilution by factors of 10 or 100. The assay of $\mathrm{CO}_{2}$ and compounds derived therefrom is particularly problesatical. The term CF, NCA, and CA (see Specific Activity and Stolchicmetry) should be used in the strictest sense in order to remove the confusion about carrier state introduced by virtually all groups working in the fleld up to about $1979(303,389)$.

The decay of carbon-1I leaves behind a boron-1I atom which is multiply charged and which leaves the site originally binding the carbon-11 precursor. The molecular "debris" left behind by this decay event can be in the form of a totally fragmented molecule or a highly excited molecular spectes which can then foril a new molecule which may or may not influence its surroundings in a deleterious way. While the chemical and blological consequences of $s$-decay have been revieved in detail (423). blological consequences of $\mathrm{B}^{+}$decay have 
just begun to receive attention (424). As the use of $\mathrm{B}^{+}$emitter proliferates in medical procedures, this area must receive attention. This is particularly apparent wtien one considers the fact that sites connected with compounds labeled with positron emitters can include. receptors, nuclear material, and other physiologically active areas, to which damage could lead to irreversible changes.

Much can be learned and applied from the many techniques developed in connection with tritium and carbon-14 syntheses (see Appendix 2). This is especially true with regard to vacuum line and micromanipulation methods. Nevertheless the use of positron emitters present their own unique and new problems and much remains to be learned.

Labellng with elements which are positron emitters, espectally carbon-11 and nitrogen-13, because of their multiple valency, present challenges to the syothetic organic chemist which require innovation and sophistication and which should provide a stimulus to those who are entering this rediscovered and burgeontng field. 
FLUOR INE-18

Fluorine-18 as a Label for Radlotracers

In a number of ways, fluorine-18 is the most attractive nuclide for positron emission tomography. The average range of fluorine-18's relatively low energy positron is 2.4 mn before annihilation occurs (Table I). This short range before annihflation w1ll become increasingly important as the resolution of positron emission tomographs improves. In addition the 110 minute half-life allows a comparatively long synthesis and the transportation of the radiotracer over moderite distances, as well as, the study of relatively slow biological processes.

In addition to the decaw characteristics of fluorine-18, the physical properties of the fluorine atom itself and the characteristics of the C-F bond also contributes to its popularity as a label for radiotracers. For example, fluorine has a sigilar van der Waal's radius to hydrogen (425) and Its substitution for hydrogen causes 1ittle steric perturbation compared to substitution with other halogens (426). Its electronegativity, however, is far greater than that of the other halogens and the carbon-fluorine bond energy is very high (425). Thus the chemical and blochemical properties of an organofluorine compound could be drastically altered with respect to the unsubstituted analog.

Although fiuorine, in chemical combination with carbon, occurs oniy rarely in aature, the development of synthetic approaches for its substitution for bydrogen or other functional groups in organic molecules has often resulted in molecules with intriguing biological properties. Frequently, the alteration of chemical properties brought about by fluorine substitution provides Information about biochemical processes and the study of the behavior of the carbon-fluorine bond In living systems as an active area of research 426-430).

Ceneral Comments on the Preparation of $18_{\mathrm{F} \text {-Labeled Radiotracers }}$

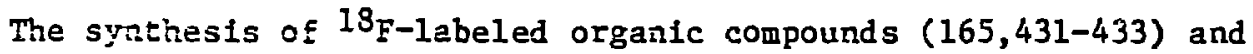
18 F-labelad inorganic compounds (167) has been reviewed and a listing of

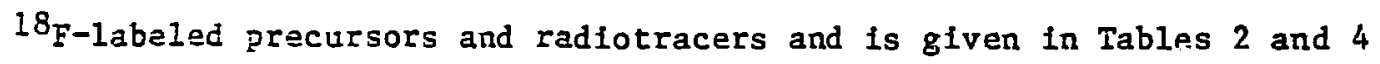
respectively. The extension of the synthetic methodology of organofiuorine chemistry to the synthesis of 18 -labeled tracers is frequently hampered by the many anomalies and experimental difficulties associated with $C-F$ bond formation. Usually, the development of a practical route to an 18 F-labeled radiotracer involves the Initial development of a synthesis to the unlabeled molecule which can then be applied the synthesis of the radiotracer. Along 
these 1ines, the use of fluorine-18 as a tracer can add a new dimenston for exploring the kinetics and mechanism of C-F bond formation in organic synthesis ( 327 ).

Frequently fluorination reagents are highly reactive molecules sich as $\mathrm{F}_{2}, \mathrm{CF}_{3} \mathrm{OF}, \mathrm{ClO}_{3} \mathrm{~F}, \mathrm{XeF}_{2}$ and $\mathrm{HF}$ and their safe effective use requires special handling. When high specific activity radiotracers are required, the normally encountered problems of chemical reactivity are amplified due to hfgh ratio's of substrate to ${ }^{18} \mathrm{~F}$-labeled precursors and contaminants which can deactivate the fluorination reagent. In the following sections, references to general articles containing information on experimental techniques will be given.

This monograph will deal with three categorles of fluorination reaction, namely, aromatic fluorination, substitutions by fluoride on aliphatic compounds and electrophilic fluorination. Although examples involving fluorine-18 will be emphasized, general reactions which are of preparative value $1_{\text {ti }}$ organofluorine chemistry, especially recent work will also be mentioned. These reactions which are tabulated in the following sections may or may not be useful to labeling with $18_{\mathrm{F}}$ and are Intended as a guide as a stimulus for exploring new ways of introducing fluorine-18 into organic molecules. Factors which need to be explored before applying any new fluorination procedure to radiotracer synthesis with F-18 are the time scale of the reaciion, whether the appropriate precursor forms of ${ }^{18} \mathrm{~F}$ could be prepared and whether the reaction stoichiometry would accommodate the use of

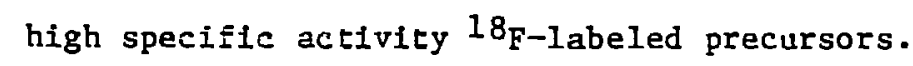

\section{F-Labeled ArFl Fluorides}

The nost generally useful method for the introduction of fluorine into an aromatic ring is the Balz-Schieman reaction first described in the late nineteenth century ( $433 a)$. This reaction was also one of the first methods of

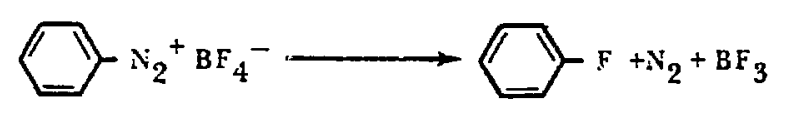

synthesis of $18_{\mathrm{F}-l a b e l e d}$ aryl fluortdes. The source of $18_{\mathrm{F}}$ in these syntheses was elther $18_{\mathrm{F}}$-labeled fluoride from the water target (309), $\mathrm{HB}^{18_{\mathrm{F}}}$ (310), $\mathrm{LiB}^{18} \mathrm{~F}_{4}(306)$, or an unidentified $18 \mathrm{~F}$-species from the recirculating neon target $(135,308)$. Since the specific activity as well as the total activity which could be produced by thls route was low due to isotope dilution, other

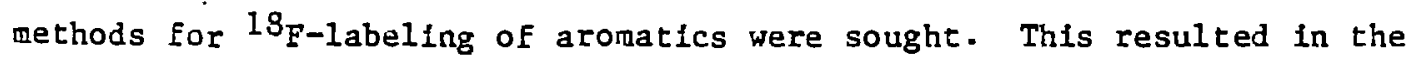
successful application of another reaction which was first described in the late 19 th century (434), nazely the decomposition of aryl triazenes by $\mathrm{H}^{18} \mathrm{~F}$ 
(324,435-437). Although this resulted in the production of carrier free or near carrier-free ${ }^{18} \mathrm{~F}$ labeled radiotracers such as haloperidol and spiroperidol the radiochemical ylelds of these reaction are very low. The scope and conditions for triazene reactions have been studied $(321,323,323 a, 437)$ from the standpoint of solvents and substrate complexity.
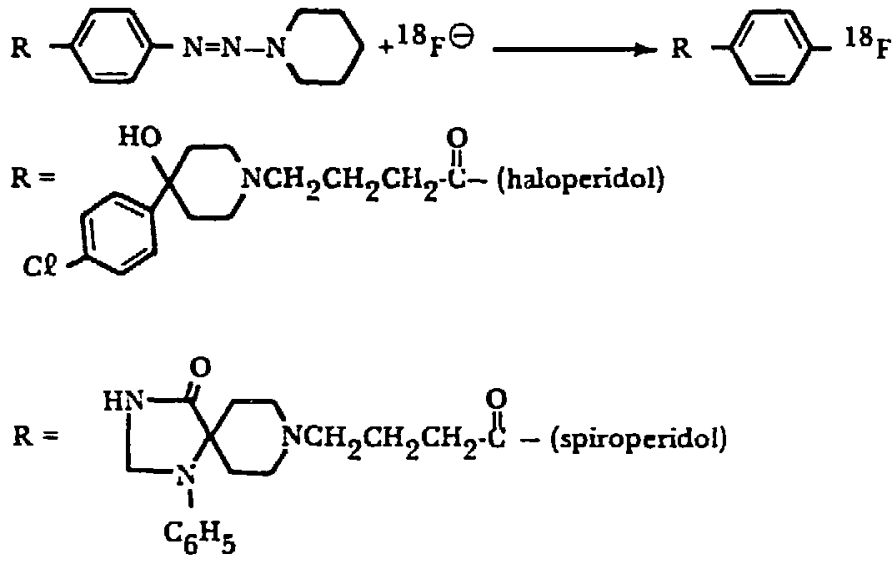

Thus far rinis reaction has used $18_{\mathrm{F}}$ in the form of anhydrous $\mathrm{Cs}^{18_{\mathrm{F}}}$ which $1 \mathrm{~s}$ obtained $\forall$ ia anjodrous $\mathrm{H}^{18 \mathrm{~g}}$ from the $\mathrm{H}_{2} / \mathrm{Ne}$ target. While the low yield and lack of reproducibility of the triazene decomposition as well as target delivery of $\underline{g}^{18} F$ are presently drawbacks to the use of this method, it's development represents a impropement over the Schiemann reaction both in terms of the stability of the triazene and increasing specific activity. The need for an efficient synthesis for aryl fluorides should provide the stimulus for Identifying the factors which are important to high radiochemical ylelds and reproducibie delivery of $\mathrm{y}^{18_{F}}$ from the target.

The use of nucleophilic aromatic substitution as a route to ary 1 fluorides was explored with a view to applying this reaction to $18_{\mathrm{F}-1 \mathrm{abel}}$ ing. In one such study of the displacement by fluoride of a sulfonate leaving group as a route to fluoroaronatics, it was found that fluoride attack occurred at sulfur rether than at carbon resulting in the ultimate production of diaryl ethers and dezcostrating that this particular leaving group was not useful in effecting the desired transformation (438). In contrast, nucleophilic aronatic substitution of activated fluoride by $\left[{ }^{18} \mathrm{~F}\right]$ fluoride proved to be quite e facile zeaction and in effect an $18_{\mathrm{F}}$ for ${ }^{19} \mathrm{~F}$ exchange reaction took place. Altiough the use of an isotope exchange reaction precludes the synthesis of $\mathrm{ICA}_{\mathrm{A}}$ tracers it has been possible to achieve reasonably high specific activity [18 F]-aryl fluorides using this method (328). The possibilities for applying this facile reaction to radiotracer synthesis are 


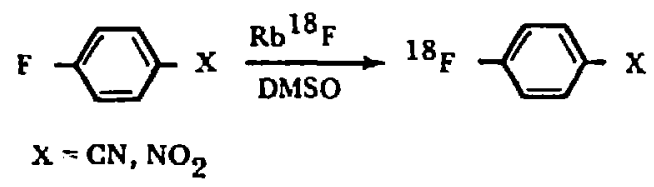

many when one considers the potential functionality which can be dertved from the cyano and nitro groups.

In another recent development L-3-methoxy-4-hydroxyphenylalanine 20 was fluorinated directly with $\mathrm{XeF}_{2}$ to give L-6-fluorodopa 21 after hydrolysis (316). This synthesis represents a signiflcant improvement over the Schiemann reaction which was previously used for the preparation of the 5-fluoro isomer<smiles>CCOC(=O)C(N)Cc1ccc(O)c(OC)c1</smiles>

(L-isomer) 20

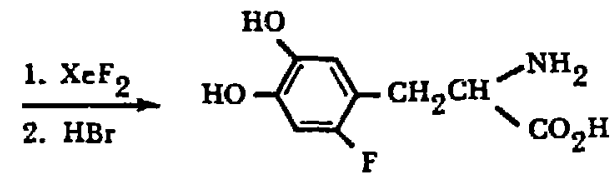

(L-isomer) 21

and which yielced the $D, L$-mixture $(308,312-314)$. When this reaction is carried out in the presence of $18 \mathrm{~F}$-labeled tetrabutylammonium fluoride a low

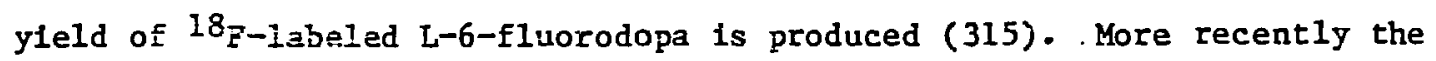
synthests of $\left.\left[{ }^{18}\right]_{F}\right] \mathrm{XeF}_{2}$ from $\mathrm{XeF}_{2}$ and $\mathrm{H}^{18_{\mathrm{F}}}$ in $31 \%$ radiochemical yleld has been reported thus extending the utility of this reagent in $18 \mathrm{~F}$-labeling (143). The avallebility of other $18_{F}$-labeled forms of electrophilic fluorine such as [18 $\mathrm{F}_{2}$ (130) and $\mathrm{CH}_{3} \mathrm{CO}_{2}{ }^{18} \mathrm{~F}$ (139) make this a promising approach for fluorinating electron rich aromatic rings in applications where carrier free radiotracers are not required.

Sowe other recent examples of aromatic fluorination with inactive fluorine bave been described and although they are not of general use, they may be useitu? in the fluorination of certain molecules. For example, $F_{2}(327,439), \mathrm{AgF}_{2}(440), \mathrm{XeF}_{2}(441-442)$ and $\mathrm{CsSO}_{4} \mathrm{~F}$ (443) have all been reported to be of limited utility in the monofluorination of certain aromatics and may be of use in certain applications where carrier fluorine can be tolerated. The electrophillc reagent $\mathrm{CF}_{3} \mathrm{OF}$ has been used to fluorinate certain aronatic molecules (444) but again it would not be possible to synthesize carrier-free radiotracers using this reagent. Phenyl azide and phenylhydroxylamine have both been shown to react with $\mathrm{HF}$ to give p-fluoroantline (445-446) and since these reactions use th they may be of use in the syatinesis. of carrler free compounds. The aryl azlde decomposition has been studied with a view to $18 \mathrm{~F}$-labeling and it was found that oxygen or large alkyl groups ortho to the azide function interfered with the fluorination (437). Fluoroaronatics without nitrogen or oxygen substituents have been prepared by thallation followed by fluoride introduction but extension of this reaction to $18 \mathrm{~F}-1$ abeling would require addition of carrier fluorine (447). 
Since these examples from the recent chemical literature were not developed with a view of $18_{\mathrm{F}-1 \mathrm{abeling}}$, their potential use in $18_{\mathrm{F}-1 \mathrm{abeling}}$ must be considered in the light of the many pitfalls and restraints which half-life, precursor availability, stolchlometry and specific activity requirements 1mpose. As can be seen, the need for a general synthetic route to NCA [18F]-aryl fluorides which gives a high radiochemical yleld still remains one of the many challenges in this field.

Substitution by Fluoride ( $18_{\text {F-Labeled Aliphatic Compounds) }}$

A detailed review has been published on the synthesis of monofluoro aliphatic compounds (448). It covers the substitution reactions of fluoride along with the addition and substitution reactions of $\mathrm{HF}$ and includes discussion of the scope and mechanistic aspects of these reactions. This along with textbooks on organlc fluorine chemistry provides a reasonably up to date survey on the progress of organofluorine chemistry as well as practical details on the use of fluorination reagents such as $\mathrm{HF}, \mathrm{CF}_{3} \mathrm{OF}$ and $\mathrm{ClO}_{3} \mathrm{~F}(439,449)$. This chapter as well as a recent review article provide considerable inforatition on preparing anhydrous fluoride salts (450). When HF is required for small scale exploratory work, it can be conveniently and safely generated by the thermal decomposition of $\mathrm{NaHF}_{2}$ (451).

Although the formation of carbon-fluorine bonds by the nucleophilic displacenent of an appropriate leaving group is formally a simple reaction, In practice, this is often not the case. A major problem is the lack of reactivity of fluoride in the presence of water due to its high solvation energy (439). Solutions of fluoride salts with large cations in aprotic solvents are a good source of fluoride which is unsolvated and therefore highly nucieophilic (448). Unfortunately, fluoride in this medium is also highly basic causing a competition between displacement and elimination

$$
\mathrm{R} \cdot \mathrm{CH}_{2} \mathrm{CH}_{2}-\mathrm{X}+\mathrm{F}^{-} \longrightarrow \mathrm{RCH}_{2} \mathrm{CH}_{2}-\mathrm{F}+\mathrm{RCH}=\mathrm{CH}_{2}
$$

reactions. This is exemplified by the widespread use of fluoride ion as a base in wany synthetic applications (450).

Tnese problems of coupeting reactions and fluoride solvation are magnified it the labeling of organic molecules with fluorine-18 espectally when high specific activity products are required and little or no carrier fluoride is used. At these levels, minute tracers of water can completely solvate the fluoride ion rendering it unreactive in displacement reactions.

A number of methods have been used to Increase the reactivity of fluoride in aucleopiflic displacement reactions. For example, the use of crown ethers, 
bulky cations, large polarizable alkal 1 metals and dipolar aprotic solvents have all met with sone success (448). (See Table 4).

Several of these approaches have been applied to labeling with $18_{F}$. In syntheses using $18_{\mathrm{F}}$ - from the water target, the reactivity of the $18_{\mathrm{F}-\mathrm{r} \text { luoride }}$ (after careful drying) is increased by using bulky cations or by using crown ethers. For example, 13 F-6-deoxy-6-fluoro-D-galactopyranose has been prepared using tetraethylammoniun $\left[{ }^{18} \mathrm{~F}\right]$ fluoride in acetonitrile (342). The use of $\mathrm{K}^{18} \mathrm{~F}$

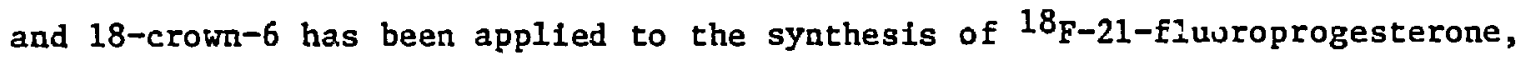
and 21-fluoropregnenolone-3-acetate (335-337) as well as to the $18_{\mathrm{F}}$ for $\mathrm{F}$ exchange on benzotrifluoride (358). 18F-labeled $a-D-g l u c o s y l$ fluoride has been prepared by the reaction of tetra-0-acetyl-a-D-glucosyl bromide with $\mathrm{Ag}^{18} \mathrm{~F}$ in acetonitrile (343).

The conversion of aqueous $\mathrm{B}^{18_{F}}$ from the water target to a useful nucleophilic form of $18_{F}$ for labeling continues to be a challenge. The problems center around the difflculty of dissolving the ${ }^{18} \mathrm{~F}$ in an approprlate reaction eediun, after the water has been removed. A model synthesis, the nucleophilic displacement of the mesylate of 21-hydroxypregn-4-ene-20-dione by $18 \mathrm{~F}$-fluoride (NCA) was chosen to explore this problem. It was found that ${ }^{18} \mathrm{~F}$-trapped in potassium hydroxide and evaporated to dryness in a tefion vessel corld be solubilized in a chloroform/crown ether system. Using these conditions it was possible to oobtain $21-\left[18^{F}\right]$ fluoroprogesterone (NCA) (335-336). The $18_{F}$ for $F$ exchange on benzotrifluoride has been investigated as a function of carrier concentration (358). Again the major problem was removal of the ${ }^{18} \mathrm{~F}$ from the glass vessel walls. Another approach to the solubilization of anhydrous carrier-free ${ }^{18} \mathrm{~F}$ from the water target is to convert it to $E^{18} \mathrm{~F}$ (anhydrous) which is distilled into an appropriate reaction medium (135).

The probless of ${ }^{18} \mathrm{~F}$-labeling at low carrier concentrations are well illustrated by a study of the $F$ for $B r$ exchange labeling of long chain fatty acids witn $18_{\bar{Z}}$ in molten acetamide (332). It was found that at carrier

$$
\mathrm{K}^{1 \mathrm{~S}} \mathrm{~F}+\mathrm{BrCH}_{2}\left(\mathrm{CH}_{2}\right)_{15} \mathrm{CH}_{2} \mathrm{CO}_{2} \mathrm{CH}_{3} \underset{150^{\circ}}{\stackrel{\mathrm{CH}_{3} \mathrm{CONH}_{2}}{\longrightarrow}}{ }^{18} \cdot \mathrm{CH}_{2}\left(\mathrm{CH}_{2}\right)_{15} \mathrm{CH}_{2} \mathrm{CO}_{2} \mathrm{CH}_{3}
$$

concentrations less than $1 \mathrm{mg}$ of $\mathrm{KF}$, the yield dropped drastically indicating that this reaction would not be applicable to the carrier free state.

No carrier added displacements have been carried out using anhydrous $\mathrm{y}^{18_{\mathrm{F}}}$ from the lie/ $\mathrm{H}_{2}$ target. The $\mathrm{H}^{18} \mathrm{~F}$ is trapped on $\mathrm{CsOH}$ or $\mathrm{Cs}_{2} \mathrm{CO}_{3}$ which is thea added to an appropriate reaction mixture. Using this method, $18_{\text {F-labeled }}$ 

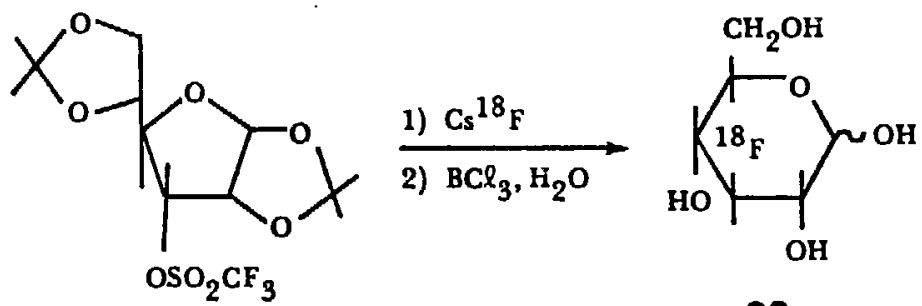

22

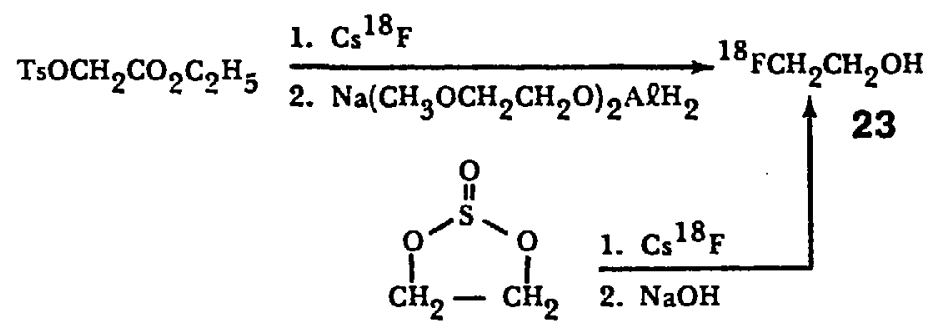

3-deoxy-3-fluoro-D-glucose 22 (124) and 2-fluoroethanol 23 (363) as well as 7-fluoropaimftic (334) acld have been synthesized at NCA levels.

The combination of leaving group, fluoride ton source, solvent and reaction conditions to effect a given transformation is not presently predictable often necessitating a trial and error approach. In one study,

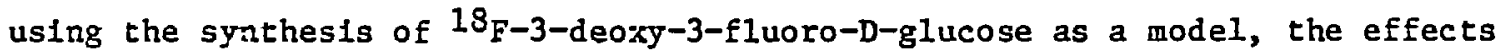
of solvent, temperature, lons, leaving groups and water on the displacement reaction were 1nvestigated (352). This study was done with a view to obtaining useful information for making rational choices of reaction parameters and was done with fluoride carrier added.

Sone erangles of fluoride displacement reactions were selected from the recent literature ( $T a b l e ~ 7)$ to update the excellent treatment of this subject which has already appeared $(439,448-449,452-453)$. These references are to unlabeled fluoride and serve as a guide to combinations of fluoride salts and solvents used in various applications with a caution to the difficulties encountered with 18 at low carrier concentrations. This is an especially important consideration in reactions where $\mathrm{HF}$ is used as a solvent or in large excess . 
Table 7. Some examples of substitution by fluoride

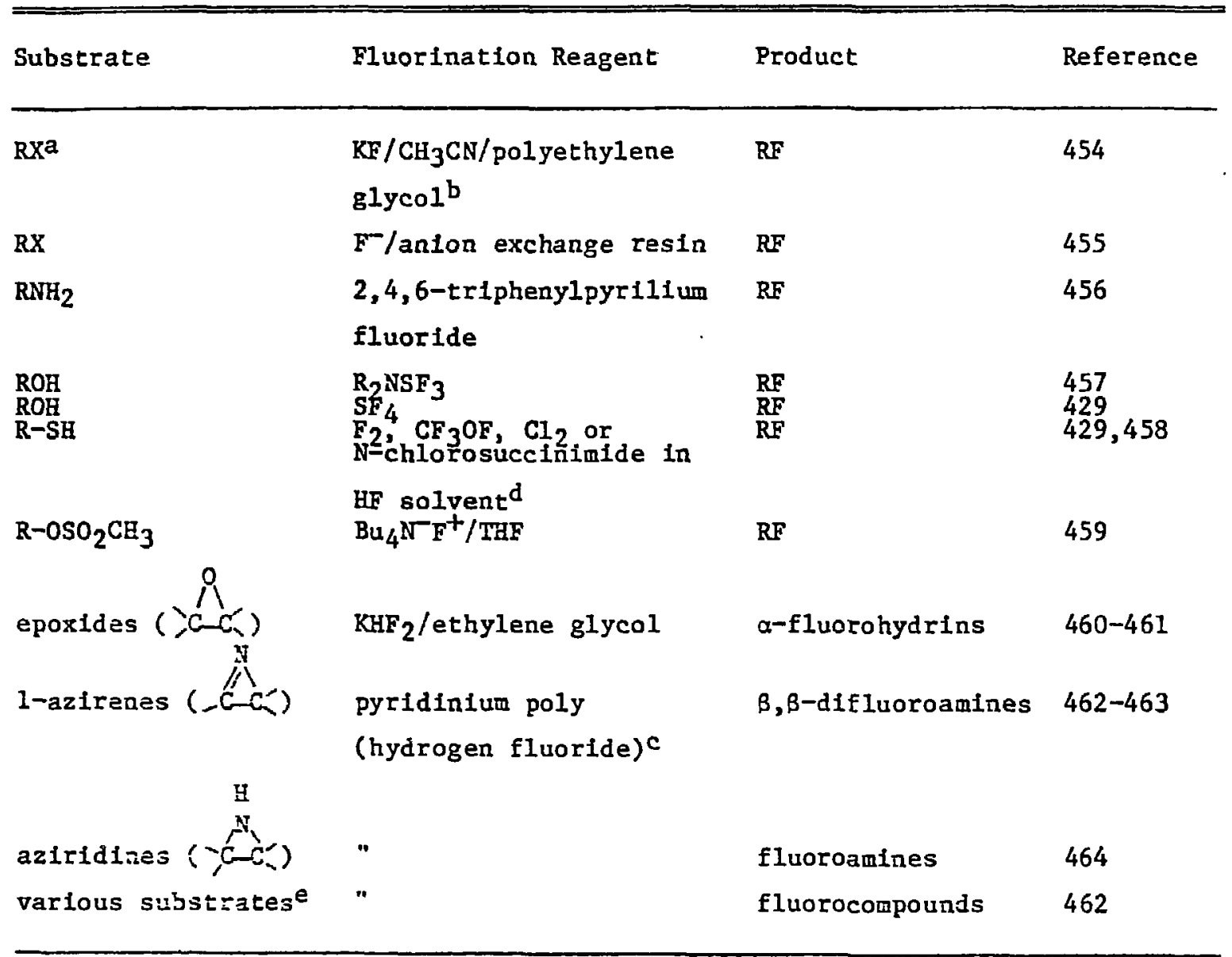

a. $\mathrm{RX}=A \mathrm{ACOCl}, \mathrm{RCOCl}, \mathrm{ArSO}_{2} \mathrm{Cl}, \mathrm{ArCH}_{2} \mathrm{Br}$, cyclo- $\mathrm{C}_{6} \mathrm{H}_{11} \mathrm{Br}, 2,4-\left(\mathrm{NO}_{2}\right)_{2} \mathrm{C}_{6} \mathrm{H}_{3} \mathrm{Cl}$.

b. Phase transfer catalyst.

c. Pyridintu poly (hydrogen fluoride) is a convenient source of HF which effects a large number of addition and substitution reactions. Isotope dilution would limit its use in radiotracer synthesis'.

d. HF solvent is the source of fluorine, and the dilution of isotope would lead to exceedingly low specific activity products.

e. Olefins, amino aclds, aminoarenes, carbamates, geminal dihalides, 
Electrophilic Fluorination as a Route to ${ }^{18} \mathrm{~F}$-Labeled Compounds

The formation of carbon fluoride bonds by electrophilic fluorine (formally $F^{+}$) usually involves the reaction of a molecule which is polarized so that fluorine is electrophilic (for example $\mathrm{CF}_{3} \mathrm{OF}, \mathrm{F}_{2}, \mathrm{ClO}_{3} \mathrm{~F}, \mathrm{XeF}_{2}$ or $\mathrm{CH}_{3} \mathrm{CO}_{2} \mathrm{~F}$ or possibly NOF) and an electron rich substrate such as an unsaturated molecule, a carbanion and in some cases a carbon-hydrogen single bond. Using $\mathrm{F}_{2}$ as the source of electrophilic fluorine, these reactions can be formally represented as follows:

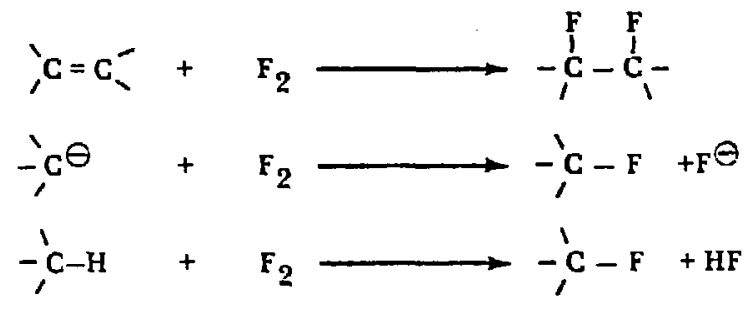

Although in organofluorine chemlstry, $\mathrm{CF}_{3} \mathrm{OF}$ is used more frequently as a source of electrophilic fluorine, the use of $F_{2}$ frequently gives very similar results. Traditionally, the use of $F_{2}$ in organlc synthesis has been avoided due to its higin reactivity and reputation for extensively degrading organic molecules (439). Recently, however, techniques for moderating 1ts reactivity have been worked out allowing its use in organic synthesis to be explored. It has been found that esters, nitrates, $3^{\circ}$ alcohols, epoxides, ketones and chlorine are stable to $F_{2}$ while bromine, olefins and esters are reactive (465). The moderacion of the reactivity of $F_{2}$ is achleved by diluting it with an inert gas and carryling out reactions at low temperatures (465) and references thereln). Furthermore, it is not necessary to handle pure fluorine since gixtires of $F_{2}$ in an luert gas and gas regulators and other equipment required for handling $F_{2}$ are commerclally avallable (Matheson Company, Inc. Rutherford, N. J.). Unlike AF, the reactions of elemental fluorine can be carried out in glass vessels and the diluted gas is conveniently transported In stainless steel or monel manifolds using valves of the same materials. Since elewental fluorine is a highly toxic and reactive gas, the reader is directed to sources of information on its safe handiing $(449,466-467)$. 
A number of $18 \mathrm{~F}-1$ abeled elecrophilic fluorination reagents which have

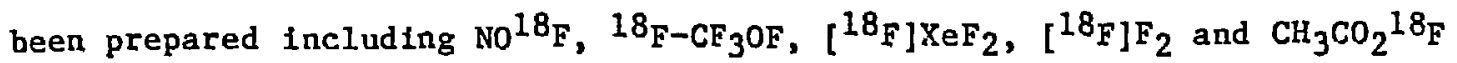
(see Table 2). Of these, only $18_{\mathrm{F}-\mathrm{F}_{2}}$ has been used extensively in the synthesis of radiotracers. The targetry for routinely delivering large quantities of $\left[{ }^{18} \mathrm{~F}\right] F_{2}$ has been described in detall along with some of the factors influencing its recovery from the target. Although it is not possible to produce ${ }^{18} \mathrm{~F}-\mathrm{F}_{2}$ carrier free, it is possible to obtain high recoveries from the $\left(\mathrm{Ne} / \mathrm{F}_{2}\right)$ target with as little as $20 \mu \mathrm{mol}$ of $\mathrm{F}_{2}$ carrfer. A number of ${ }^{18} \mathrm{~F}$-labeled radiotracers have been syathesized using [ $\left.{ }^{18_{F}}\right]_{2}$ including 18 F-labeled 5-fluorouracil 24 (353-354),

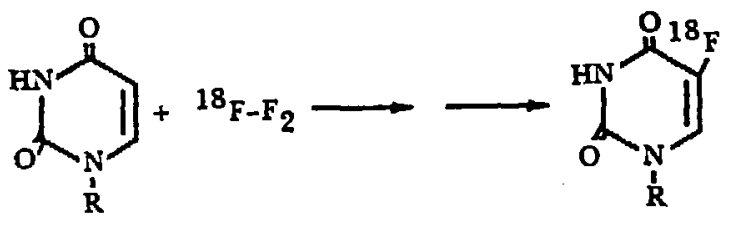

$R=\mathbf{H}$

24

ribosyl

2'-deoxyribosyl<smiles>Cc1cc(=O)n(-c2ccccc2)n1C</smiles>

25

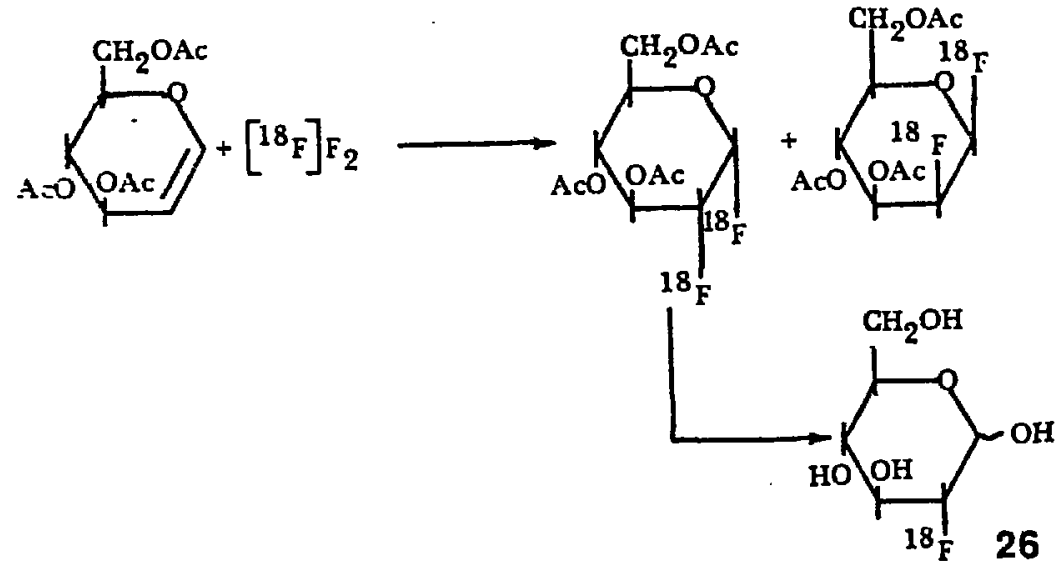

5-fluorausidine (357), 5-fluoro-2'-deoxyuridine (355), 4-fluoroantipyrine 25 (366), and 2-deoxy-2-fluoro-D-glucose $\underline{26}$ (344-346) and fluorobenzene (326). Interestingly, most of these reactions have also been reported using $\mathrm{CF}_{3} \mathrm{OF}$ supporting the similarity in the reactions of $\mathrm{CF}_{3}$ OF and $F_{2}$. 
Acetyl hypofluorite, which was recently syntheslzed from the reaction of sodium acetate and $F_{2}(468)$, has been labeled with fluorine-18 by simply purging $\left[{ }^{18} \mathrm{~F}_{\mathrm{F}}\right.$ from the Ne/F 2 target through a solution of amonium acetate in acetic acid (139). The resulting solution of $\mathrm{CH}_{3} \mathrm{CO}_{2}{ }^{18} \mathrm{~F}$ has been used in

$$
\left[{ }^{18} \mathrm{~F}\right] \mathrm{F}_{2}+\mathrm{CH}_{3} \mathrm{CO}_{2} \mathrm{NH}_{4} \stackrel{\mathrm{CH}_{3} \mathrm{CO}_{2} \mathrm{H}}{\longrightarrow} \mathrm{CH}_{3} \mathrm{CO}_{2}{ }^{18} \mathrm{~F}+\mathrm{NH}_{4}{ }^{18} \mathrm{~F}
$$

the synthesis of 18F-2-deoxy-2-fluoro-D-glucose (349). This development

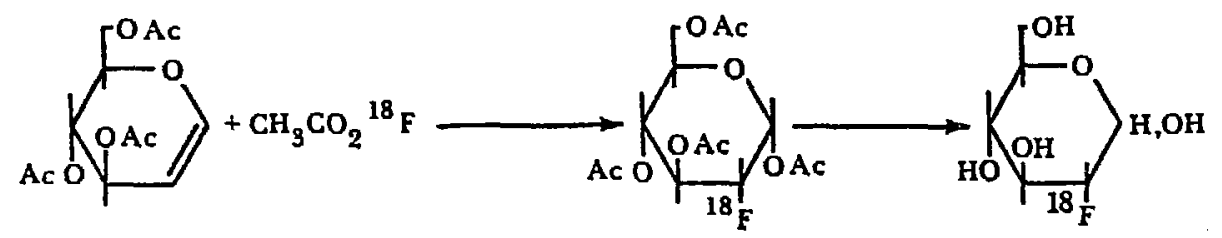

represents a significant improvement over the synthesis described above using $F_{2}$ because only one adduct is formed, the experimental setup is simplified and the yield is increased (see Experimencal Design-Examples).

The syathesis of monofluoroaliphatic compounds has been reviewed ani many examples tebulated, including the reactions of $\mathrm{CF}_{3} \mathrm{OF}, \mathrm{ClO}_{3} \mathrm{~F}$ and $\mathrm{NOF}$ and experluental procedures for handling these highly reactive gases (448). In addition, there are some interesting new developments in the use of these reagents as well as the 1 n situ synthesis of novel electrophilic reagents and their use in organic synthesis. Some examples from the recent literature have been tabulated to illustrate the diverse structures which can be obtained using electrophilic fluorination reagents (see Table 8). The extension of

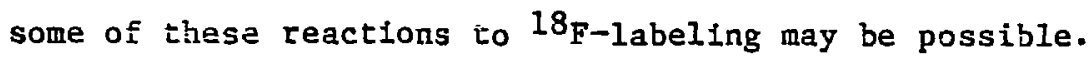


Table 8. Some examples of electrophilic fluorination reactions

\begin{tabular}{|c|c|c|c|}
\hline Substrate & $\begin{array}{l}\text { Fluorination } \\
\text { Reagent }\end{array}$ & Product & ference \\
\hline $\begin{array}{l}\text { stilbenes and } \\
\text { diphenylacetylene }\end{array}$ & $\mathrm{CF}_{3} \mathrm{COOF}^{\mathrm{a}}$ & $\alpha$-fluorohydrins & 469 \\
\hline enol-acetates & $\mathrm{CF}_{3} \mathrm{CF}_{2} \mathrm{OF}^{\mathrm{b}}$ & $\alpha$-fluoroketones & $470-471$ \\
\hline enol-acetates & $\mathrm{XeF}_{2} / \mathrm{HF}$ & $\alpha$-fluoro-ketones & 472 \\
\hline a-dlazoketones & $\mathrm{CF}_{3} \mathrm{OF}$ or $\mathrm{F}_{2}$ & $\alpha, \alpha-d i f 1$ uoroketones & $473-474$ \\
\hline silyl enol ethers & $\mathrm{CF}_{3} \mathrm{OF}$ & $\begin{array}{l}\alpha \text {-fluoro carbonyl } \\
\text { compounds }\end{array}$ & 475 \\
\hline $\mathrm{R}_{3} \mathrm{CH}$ & $\mathrm{CF}_{3} \mathrm{OF}$ or $\mathrm{F}_{2}$ & $R_{3} C-F$ & $476-479$ \\
\hline olefins and aromatics & $\mathrm{CF}_{3} \mathrm{OF}$ & $\begin{array}{l}\text { mono and difluoro } \\
\text { compounds }\end{array}$ & 444 \\
\hline $\begin{array}{l}\text { olefins, acetylenes } \\
\text { and aromatics }\end{array}$ & $\mathrm{XeF}_{2}$ & $\begin{array}{l}\text { mono and difluoro } \\
\text { compounds }\end{array}$ & 442,480 \\
\hline RH & $\mathrm{CF}_{3} \mathrm{OF} / \mathrm{h} \mathrm{c}$ & $R-F$ & 429 \\
\hline$R-X^{d}$ & $F_{2}$ & $R-F$ & 481 \\
\hline olefins and arodatics & $\mathrm{CH}_{3} \mathrm{CO}_{2} \mathrm{~F}$ & $\begin{array}{l}\text { fluoroacetoxy compounds } \\
\text { and aryl fluorides }\end{array}$ & 468,482 \\
\hline aromatic compounds & $F_{2}$ & aryl fluorides & 483 \\
\hline
\end{tabular}

a. Generated in situ from $\mathrm{CF}_{3} \mathrm{CO}_{2} \mathrm{Na}+\mathrm{F}_{2}$ with traces of $\mathrm{H}_{2} \mathrm{O}$ or HF.

b. Generated in situ from $\mathrm{CF}_{3} \mathrm{CO}_{2} \mathrm{Na}+\mathrm{F}_{2}$ (anhydrous conditions).

c. Reaction zechantsa may involve radical formation.

d. Bromo and iodoadamantanes. 
Statistical Factors and Radiochemical Yleld

The theoretical upper limit of the radlochemical yleld of a reaction is variable depending on stoichlometry. For example in the case of a fluoride displacement reaction the theoretical naximum radiochemical yield is $100 \%$. However, in the synthesis of

$$
R-X+{ }^{18} F^{-} \longrightarrow R \stackrel{18}{F}^{-} X^{-}
$$

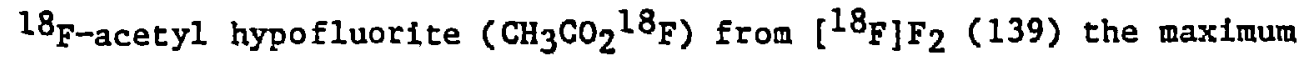
radiochemical yield is $50 \%$ because only one fluorine atom in the fluorine molecule is radioactive and there is an equal probability that the fluorine

$$
2^{18} \mathrm{~F}-\mathrm{F}+2 \mathrm{CH}_{3} \mathrm{CO}_{2} \mathrm{NH}_{4} \longrightarrow \mathrm{CH}_{3} \mathrm{CO}_{2} \mathrm{~F}+\mathrm{CH}_{3} \mathrm{CO}_{2}{ }^{18} \mathrm{~F}+\mathrm{NH}_{4} \mathrm{~F}+\mathrm{NH}_{4}^{18} \mathrm{~F}
$$

atom wich reacts with acetate ton is unlabeled. Therefore for each 2 molecules of $18 \mathrm{~F}-\mathrm{F}$, only one molecule of labeled acetyl hypofluorite is produced along with one molecule of $\mathrm{NH}_{4}{ }^{18} \mathrm{~F}$, giving a radiochemical yield of $50 \%$. The upper limit of the radiochemical yleld is even less in the case of the pyrolysis of an $18_{F}$-labeled diazonlum fluoroborate salt to produce an aryl fluoride. Here only one fluorine atom in four is labeled and therefore the

$$
4 \mathrm{ArN}_{2}^{+} \mathrm{F}-\mathrm{P}_{\mathrm{F}}^{\mathrm{B}}-{ }^{18} \mathrm{~F} \longrightarrow \mathrm{Ar}^{18} \mathrm{~F}+3 \mathrm{ArF}+\mathrm{BF}_{\mathrm{g}}+3 \mathrm{BF}_{3}{ }^{18} \mathrm{~F}+4 \mathrm{~N}_{2}
$$

maximum radiochemical yield obtainable from a speciflcally labeled diazonfum fluoroborate salt is $25 \%$.

Speclal Problems with 18F-Precursor Production and Radiotracer Development The high reactivity of fluorine and 1 ts compounds presents a particular challenge to the exploration of the nuclear reactions and target chemistry

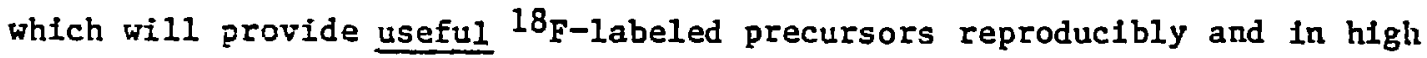
yield. The broad spectrun of accelerators (including relatively low energy nedical cyclotrons) which are currently in use for radiotracer research has required that the production of useful precursors as well as radiotracer be approached by different routes so that their availability for biomedical studies is maximized. For example, while the targetry for the routine production of large quantities of $\left[18_{F}\right] F_{2}$ on cyclotrons having high energy deuterons ( $>15 \mathrm{mev}$ ) is well worked out, targets designed for the production of large quantities of $\left[{ }^{18} \mathrm{~F}_{\mathrm{F}}\right.$ on medical cyclotrons having $\sim 3$ mev deuterons and high currents has not yet been demonstrated. An alternative reaction for 
producing $18_{\mathrm{F}}$ in large ylelds on medical cyclotrons is the $18_{0}(\mathrm{p}, \mathrm{n})^{18_{\mathrm{F}}}$ reaction (484). Along this line some of the challenging problems in the

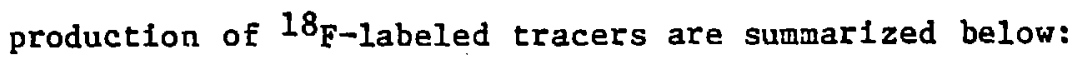

(1) Developing targets which can be used with 8 mev deuterons at high currents so that useful quantities of $\left[18_{F}\right] F_{2}$ and $H^{18} F$ can be produced on medical cyclotrons via the $20 \mathrm{Ne}(d, \alpha)^{18} \mathrm{~F}$ reaction.

(2) Determining the target chemistry for the $18_{O}(p, n)^{18} \mathrm{~F}$ reaction so that high yields of synthetically useful $18_{\mathrm{F}}$-labeled precursors such as $\mathrm{H}^{18} \mathrm{~F}$ (anhydrous) and $\left[{ }^{18} \mathrm{~F}\right] F_{2}$ can be produced on medical cyclotrons. (3) Obtaining $18 \mathrm{~F}^{-}$in nucleophilic form at high specific activity. (4) Developing and optimizing high yield synthetic routes to high specific activity 18 F labeled tracers which are of interest in the biomedical studies so that avallability is maximized.

The importance of all of these problems is well illustrated when one considers that presently 2-deoxy-2[18 ${ }^{18_{F}}$ fluoro-D-glucose (18FDG), a tracer which is in high demand from the blomedical community can only be produced at a few centers which have cyclotrons with the sufficiently high deuteron energies for producing the requisite amount of precursor [ $18_{F}$ ] $F_{2}$ for human studies. The development of the targetry which could compensate the low deuteron energies of medical cyclotrons by taking advantage of the high currents avaflable could impact significantly on the avallability of 18 FDG. Similarly, development of the appropriate target chemistry for the $18_{0}(p, n)^{18_{F}}$ reaction wey represent another solution to this problem. of equal 1mportance to the expioration new methods of $13_{F}$-precursor production should be the continued pursuit of alternate higher yield synthetic routes to such tracers as 2-deoxy-2[18 F] fluoro-D-glucose, thereby more efficlently using the isotope which is produced. 
NITROGEN-13

The ten minute half-life of nitrogen-13 presents an unusual challenge for the development of rapid methods for its incorporation into organic molecules. Because of its short half-life and potentially high specific activity, nitrogen-13, unlike nitrogen-15 can be used to study the metabolic fate of nitrogen in various systems at true tracer levels and with high sensitivity (397). It is therefore unique in its ability to act as a tracer for stable nitrogen, a factor which compensates for the Inconvenience of the 10 minute half-life and the requirement for on-site accelerator and related facilities and expertise. For example, the metabolic fate as well as the

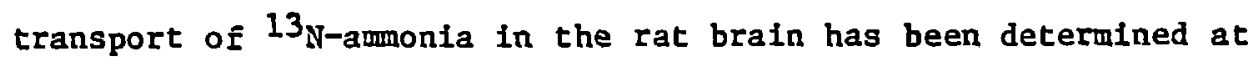
sub-physiological ammonia doses (370). In contrast, the study of ammonta

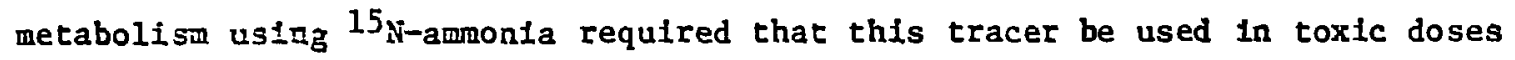
to compeasate for the low sensitivity of the detection technique (485). In another example, with ${ }^{13} \mathrm{NO}_{3}{ }^{-}$, it has been possible to measure denitrification rates in soils fron flooded rice fields at true tracer levels (145) and $13 \mathrm{~N}$ labeled nitrogen, ammonla and nitrate have been used to probe nitrogen fixation and metabolism in bacteria (393-396). The unique applications of $13_{\mathrm{N}}$ as a tracer for the retabolic fate of various nitrogen containing functional groups in organic and inorganic molecules has been recently reviewed (397). A listiag of $13_{\mathrm{N}}$-labeled precursors with selected references appears in

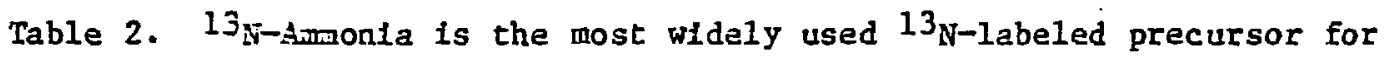
radiotracer syathesis although $13 \mathrm{NO}_{3}-, 13 \mathrm{NO}_{2}-$ and 13 No have also been used. The most eomonly used nuclear reactions are the deuteron bombardment of methane $\left({ }^{12} C(d, n)^{13} N\right)$ or the proton bombardment of water $\left(16 O(p, \alpha)^{13} N\right)$. The deuteron boabardment of methane ylelds ${ }^{13} \mathrm{NH}_{3}$ directly but also produces Impurities which must be removed by distillation (150-152). The water target yields $13 \mathrm{~N}$-labied nitrates and nitrites which can be reduced to $13_{\mathrm{N} \text {-ammonia }}$ and is presentiy the method of choice $(146,149,153-157)$. The production of

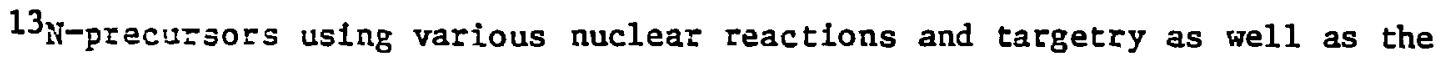
chemical form of $\mathrm{N}-13$ produced in varfous nuclear reactions and chemical environgents have been discussed (168-169,486-487).

The enzyne systems which are responsible for amonia metabolism in living systems have been exploited for the rapid, stereospectfic synthesis of

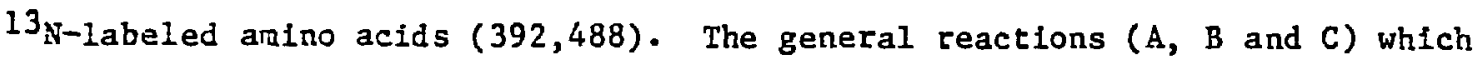
have been used are summarized below: In the general reaction $A$, glutamic acid dehydrogenase (CAD), catalyzes the formation of $13 \mathrm{~N}$-L-amino acids from ${ }^{13} \mathrm{NH}_{3}$ and an $\alpha$-keto acld. Although $\alpha$-ketoglutaric acid is the natural substrate for 
GAD, certain other $\alpha$-ketoacids also serve as substrates for this enzymn and have been used to prepare other ${ }^{13} \mathrm{~N}$-L-amino acids (see Table 5). In example $B,{ }^{13} \mathrm{~N}-\mathrm{L}-\mathrm{glutamic}$ acid is synthesized and the $13 \mathrm{~N}$ is transferred to an $\alpha$-keto acid in a reaction catalyzed by glutamate-pyruvate or glutamate-oxalacetate

A.

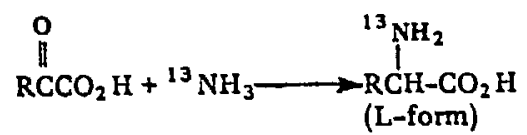

B.
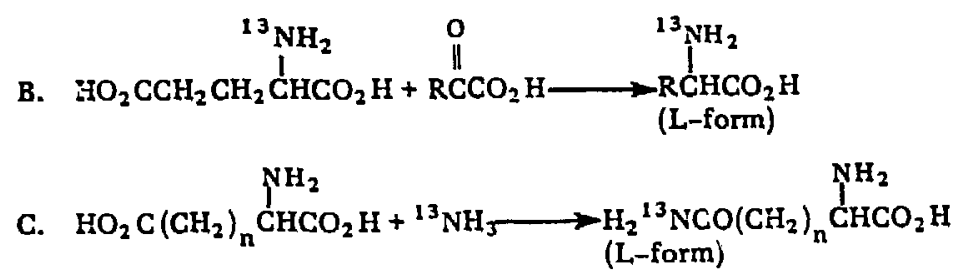

transferase. In reaction $\mathrm{C}$, an ${ }^{13} \mathrm{~N}$-amide is synthesized via the glutamine or aspargine synthetase catalyzed reaction of $1{ }^{13} \mathrm{NH}_{3}$ and the amino acid. Exanples of $I^{3}, t-L-a n i n o$ acids synthesized via these various routes are sumarized in Table 5 .

The number of enzymatically synthesized $13 \mathrm{~N}-\mathrm{L}$-amino actds has been largely linfted to those reactions which can be carried out with commercially avallable enzynes. Recently the reactivity of a variety of substrates ( $\alpha$-ketoacids) with GAD has been studied with a view to expanding the number of

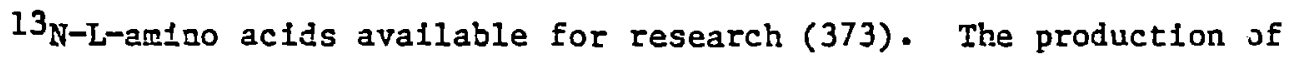

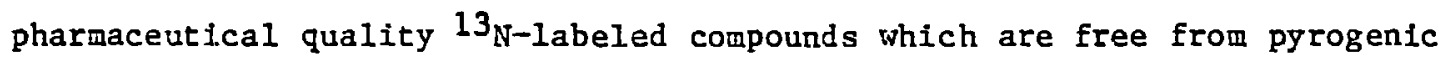
nacromolecular contamination which is present in enzyme catalyzed reactions can be overcoue in some cases by the synthetic attachment of the enzyme to a

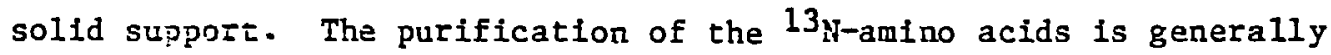
accomplished by fon exchang chromatography.

In addition to biosynthetic approaches, classical organic synthetic approaches to $13 \mathrm{~N}$-labeled radiotracers have been developed (see Table 6). For example 13 H-asparagine has been synthesized enzymatically from aspartic acid (380-381), $13 \mathrm{NaI}_{3}$ and aspargine synthetase which is not commerctally avallable. Since this enzymatic synthesis gives a low yleld and the enzyme cannot be inmobilized due to its instabllity, a rapld and efficient chemical synthesis was developed. It Involves the reaction of $\alpha-N-t-B o c-t-B u-a s p a r t a t e$ (activated with $\mathrm{N}$-hydroxysuccinimide) with $13 \mathrm{NH}_{3}$ and yields $13 \mathrm{~N}$-L-asparagine In $30-40 \%$ yield ( 384 ).

The synthesis of $13 \mathrm{~N}-\mathrm{N}-\mathrm{nt}$ trosoureas using $13 \mathrm{NO}_{3}-$ obtained directly from the water target and reduced in situ to ${ }^{13} \mathrm{NO}_{2}{ }^{-}$has been described (159). This 
is an improvement of a previously described procedure which used ${ }^{13} \mathrm{NH}_{3}$

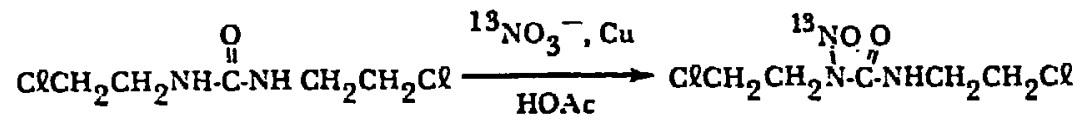

as an isotopic precursor and required its oxidation to 13 NO and $13 \mathrm{NO}_{2}$ (158). $13 \mathrm{~N}$-labeled streptozotocin and nitrosocarbaryl have been synthesized using

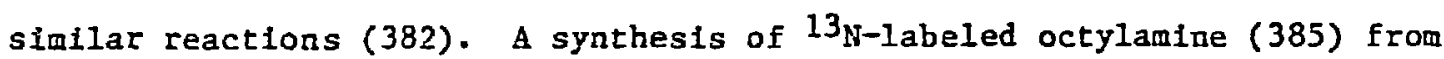

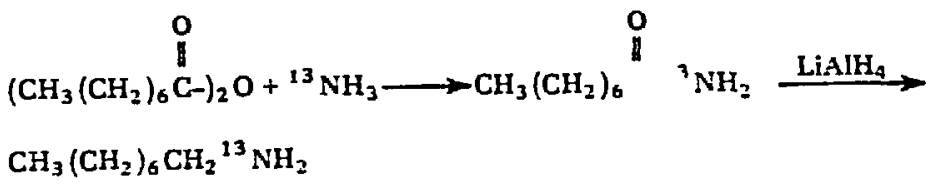

$13 \mathrm{NH}_{3}$ and oc:anoic anhydride followed by reduction has been developed as has the prepazation of $13 \mathrm{~N}$-urea (383). In addition the recent report of the synthesis of zitrogen-15-labeled primary amines via organoboranes has

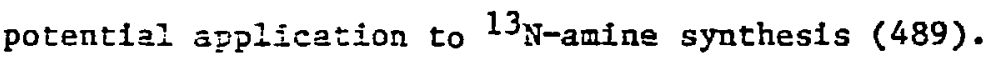

The use of an $13_{\mathrm{N}}$-labeled radiotracer requires that the blological process under injestigation is sufficiently rapid to be traced with this short-lived nuclide and necessitates the development of rapld assay systems for the $13 x-1$ ibeled tracer ind its labeled metabolites in order to determine the factors responsible for its biodistribution. In spite of the short half-life $0 \equiv i 3 \mathrm{y}$, rapid analytical methods have been developed for 1 ts study (397). For exazpla, in the study of the retabolic fate of ammonia in rat brain it has jeen found that 5 seconds after injection of $13 \mathrm{~N}$-ammonia, $\sim 60 \%$ of the lajel recovered in the brain had already been incorporated into glutamine ezphasizing the importance of glutamine synthetasa as a metabolic trap for bieod borne annonia (370). 
EXPERIMENIAL DESIGN AND RELATED TECHNOLOG

The application of positron emitting radiotracers to the study of metabolisi and function using PETT requires that the chenistry laboratory adjacent to the cyclotron be designed to accommodate and manipulate Curie levels of short-lived nuclides. This section will deal with some of the important aspects of laboratory design including radioactivity monitoring and routine production of radiotracers. Experimental detalls for the synthesis of

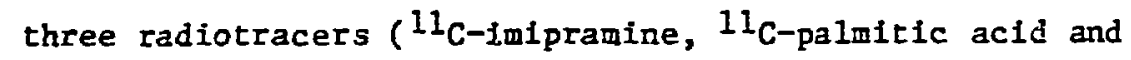

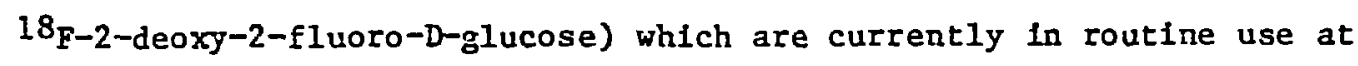
different institutions will also be used to illustrate these points.

\section{Radioactivity Assay}

The detection and measurement of radioactivity both in the microcurle range and in the hundreds of millicuries - Curie range is required in the developnent of rapid synthesis for short-lived radiotracers and also in their routine production for clinical studies. In each case an appreclation for the Iimitations of the various methods for assaying radioactivity is important as is an accurate calibration of the detector or counter. The reader is referred to al excellent sext on radiation detection and measurenent for a detalled treatment oi the subject (490) and to an article on the criteria which should be applied in choosing the approprlate assay method (49I). In this section, $a$ limited emount of practical information on the use and calibration of ion chambers and well counters and monitoring radioactivity during radiotracer synthesis, will be presented.

Ion Chamber and Well Counter Calibration: Where activity levels in excess of a total of roughly $5 \mu C i$ must be determined in one entity, the ion chamber is the only practical nethod to be used. This is the detection method employed in all so-called dose calibrators. The current measured by the fon chamber is linearly dependent on the amount of fonization taking place in the filling gas of the chamber, and this in turn is directly dependent on the amount and energy of eack component of the decay scheme of the nuclide befing used. Trerżora, in order to obtain accurate values with these instruments it is necessery to know the decay scheme of the nuclide accurately and to be able to relate tiese paraneters correctly to the inherent properties of the measuring device and its electronics. This is usually done by the manufacturer, but there have been many docunented cases where this has not been done in a satisfactory manner.

In certain cases it is possible to calfbrate these instruments very accurately. For all work in this field, a well-calibrated crystal well 
counter is needed. Such counters are relatively insensitive to variations in the energy of the photons being detected, at least over a reasonable range, and they are rather insensitive to lower energy $x$-rays (around $30-40 \mathrm{keV}$ ). This is an energy range to which ion-chambers are particularly sensitive, and this is a major contributor to their lack of precision without very careful calibration. If, however, a source of protons with an energy of at least $20 \mathrm{MeV}$ is avallable, one can Irradiate a thin plece of polyethylene for a few seconds, and by means of the ${ }^{12} \mathrm{C}(\mathrm{p}, \mathrm{pn})^{11} \mathrm{C}$ reaction produce polyethylene containing several mCi of ${ }^{1 l_{C}}$ in a small plece of foll. This foll is then placed in position in the lon chamber and readings are taken at the manufacturer's recommended setting and at a number of other settings on either side of $1 t$. The precise time at which each reading is taken must be noted, so that all readings can be decay-corrected to a common time. After allowing the foll to decay for 4-5 half lives, it can be counted in the well counter (again at a known time). If the count rate is still such that a dead-time correction should be applied, this should be done or it should be allowed to decay further. If the rell counter has already been calibrated properly, one can now simply deterdine which of the dose-calibrator settings was giving the correct reading.

If the weli-couater is not properly calibrated, at this point one can place a sinall asount of glass wool in the bottom of a standard liquid scintillation $v i a 1$, load the vial with a pure toluene or xylene-based scintillator, and place the fofl in the solution. If the sample is counted in the $32 \mathrm{P}$ channei, or in a channel with no upper discriminator setting, it has been shown by tire method described below that the efficiency for the ${ }^{11} \mathrm{C}$ positron is identical to that for the ${ }^{14} \mathrm{C}$ beta particle under such non-quencting condicions. Therefore an absolute determination can be made of either the total or the specific activity of the foil, and this can be decay corrected to tine stendard time to calculate the true activity in the foll at any desired time when the previous determinations were made.

For a precise calibration of the well counters, the welghed, activated piece of polyethylene is combusted to carbon dioxide on a system designed for the purposa, and the ${ }^{11} \mathrm{CO}_{2}$ is introduced into an Internal gas proportional counte: (492), after all other counting has been completed. The efficiency of such counters is known to $\pm 1 \%$ by both theoretical calculations and comparison with the NBS standards. After equilibration of the gas mixture in the tubes for 20-30 minutes, they can be counted and the speciffc activity of the ${ }^{11} \mathrm{CO}_{2}$, and thus the polyethylene foil, can be calculated to $\pm 2 \%$. The efficiency of the well-counter can then be calculated to the same accuracy, and this 
efficlency is valid for any "pure" positron emitter (e.g. ${ }^{18} \mathrm{~F},{ }^{13} \mathrm{~N}$, or ${ }^{15} 0$ ). Numerous comparisons of such measurements with the liquid scintillation technique described above has shown that the latter is entirely valid when used as described.

Radioactivity Monitoring During a Synthesis: Monitoring the amount of radioactive precursor delivered from a target to the synthesis area is conveniently carried out using an ionization chamber with a digital readout in a fixed geometry relative to other components in the synthesis system. These detectors operate in the range of $10 \mu \mathrm{Cl}$ to $>2 \mathrm{Cl}$ (for example Capintec Inc., Mt. Vernon, N. Y.) Such a detector can be calibrated to give an estimate of the accumulated amount of radioactivity at any time during activity transfer. Furthermore, although not highly accurate, changes in lonization chamber readings during varlous transfers are useful monitors during synthetic manipulations and provide an instantaneous indication of problem areas. This requires, of course, that the geometry of all components of the system remain fixed relative to the probe from one run to the next.

Monitoring the distribution of radioactivity among the components of a synthesis efther during a synthesis or after the synthesis is an essential step in trouble shooting a system and assessing the various factors responsible Eor yield losses. It can be done convenlently during the synthesis or after completion of the synthesis using a shielded ionization chamber with a large ( 2-7/8 in.) diameter well (for example, Capintec Inc., Mt. Vernon, liew (ork). It is useful to design the size of various system components to fit into the chamber. For assaying lower levels of activity $(<5 \mu \mathrm{Cl})$ a calsbrated well counter, is required. Automated gamma counters are useful for assaying a number of samples as, for example, in the quantitation of the distribution of radioactivity from fractions on a chromatogran or assaying tissue samples. An important consideration in the specifications for an automatic gama counter for use with short-lived nuclides is that there is considerable advantage in a rapid sample changing mechanism. This is of overriding importance when using 150 or even $13_{\mathrm{N}}$.

The desiza of laboratory space ldeally should allow low level analytical work and higi level synthesis to be accomplished simultaneously. This requires that senslifive counting equipment be located away from high level areas and/or be well shielded from high background radiation levels. This design is also compatible with avoiding contamination problems. Many problems can also be avoided if long-lived radionuclides are excluded fron the short-lived synthesis laboratory. 

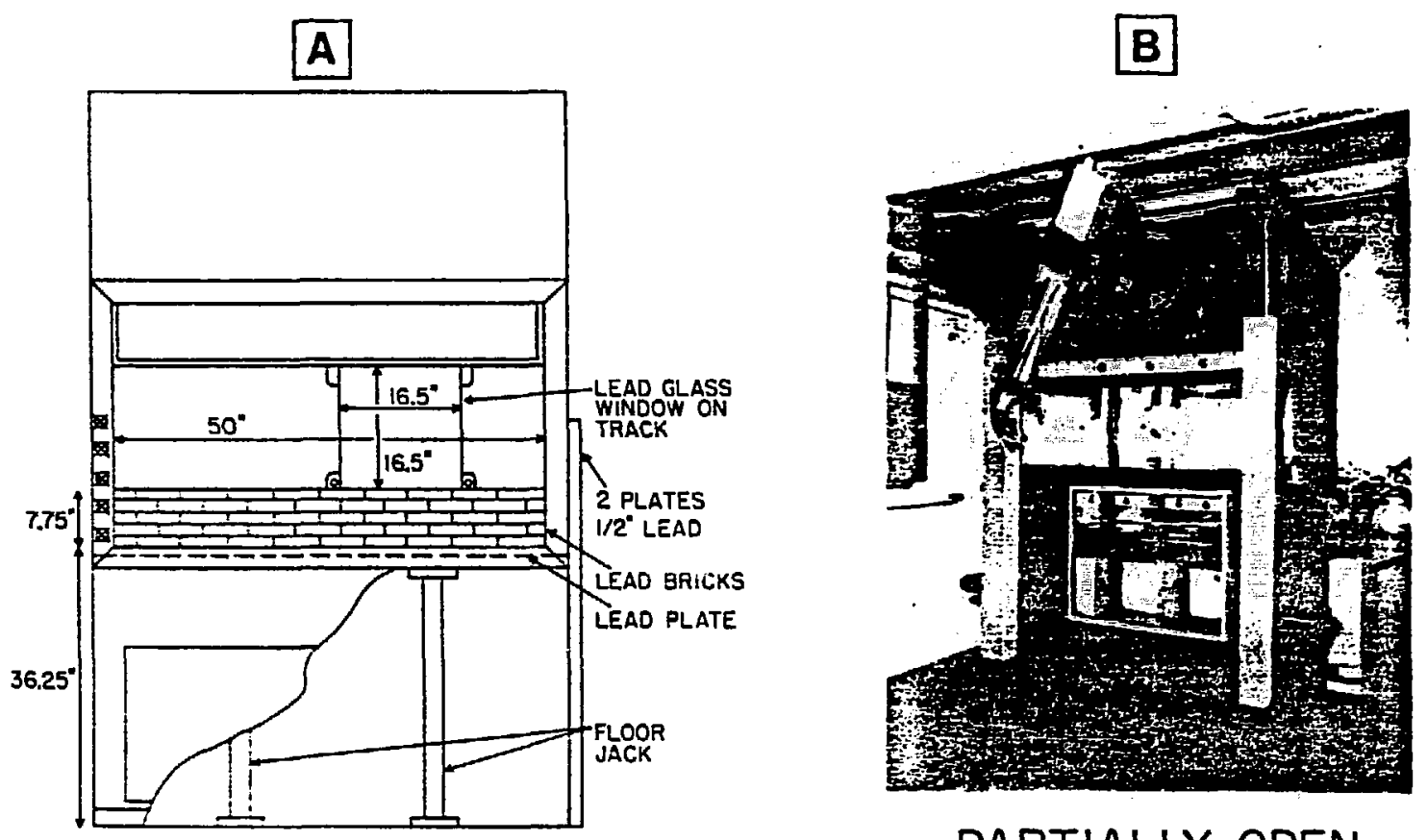

\section{PARTIALLY OPEN}
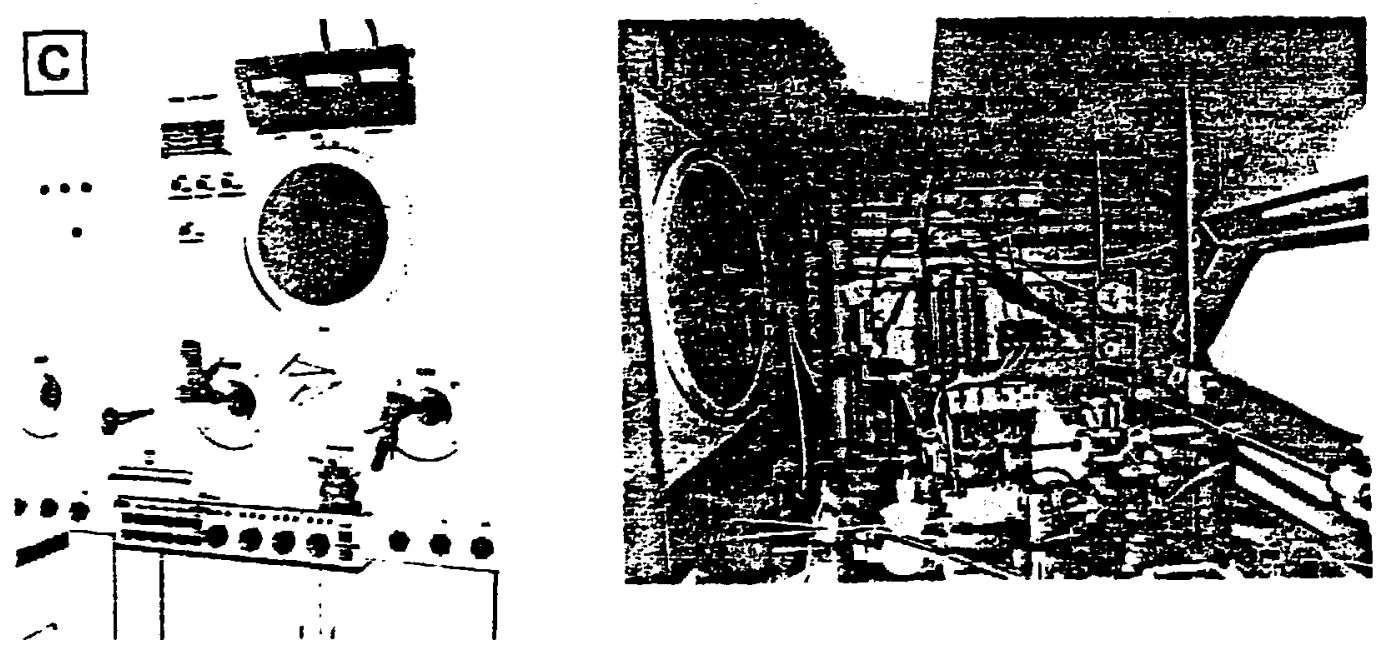

Fig. 3 Shielded work areas. A. Shielded commercial hood. B. Shielded synthesis box for use with high levels of radioactivity. C. Hot cell for remote synthesis of radiotracers (photograph provided by D. Comar). 
Shielded Work Areas

An area in which the synthesis of short-lived positron emitting tracers can be safely carried out can take many forms. Three examples, varying in cost and construction complexity will be lllustrated here keeping in mind that many different Individual designs have been developed on the basis of individual needs.

The simplest shielded work area involves modification of a commerclaily avatlable laboratory hood and is 1llustrated in figure 3A. Basically, its fabrication involves providing structural support of the floor of the hood (floor jacks) and placlng a lead plate on the hood floor. Along the entire front face of the hood, a short wall of lead bricks is bullt. On the top of this wall a high density $(6.2 \mathrm{gm} / \mathrm{cc}$ ) lead glass window $(16.5$ in high $\times 16.5 \mathrm{in}$ wide) is installed on a track so that it slides across the front face of the hood and can be used to shield different areas as the radioactivity is moved to differant areas within the hood. This provides a reasonably well shielded work area for use with moderate levels of radioactivity, especially when modular siifeldiag is used within the hood. For example, lead shielding of various vessels in which the nuclide is trapped as well as small lead shields for various reaction vessels and columns, when used inside the modifled commercial hood provides reasonably inexpensive and effective protection for manipulations which need to be carried out during a synthesis. However, when large quantities of radiotracer are required on a regular basis, the need for more shieliing escalates. This need has been met by two systems described below.

Anotiner design appears in figure 3B. Basically it is a shielded box with complete access to the front area by mechanically lowering a large lead glass window mouzced in steel frame. Behind this is a small lead glass window on a horlzontal track. The large window can be used in any position and in the fully open position gives complete access for experimental setup. Used in the partialis opea configuration (shown in flgure 3B) in conjunction with the smaller willow, this shlelded box can be used for lower level exploratory work where a completely remote or automated system has not been developed. A master-slave manipulator is also an essential feature of this system (493).

A closed shielded hood has been described for the synthesis of ${ }^{11} \mathrm{C}$-labeled radiotracers at the $\sim 100 \mathrm{mCl}$ (product at end of synthesis) level (185). The experimental setup has been integrated into the shielded hot cell and has been completely automated so that the ${ }^{11} \mathrm{C}$ can be incorporated without manual intervention at no radiation risk to personnel involved in the synthesis. This hot cell which in routine use is shown in figure $3 \mathrm{C}$. 
Routine Production of Radiotracers for Clinical Studies

The Initial development of the synthetic approach itself as well as preparing the tracer for evaluation in small animals requires working with relatively low levels of radloactivity. In contrast, the extension of these low level studies to the use of the radfotracer in humans on a regular basis using PETT usually requires the repetitive handling of large quantities of

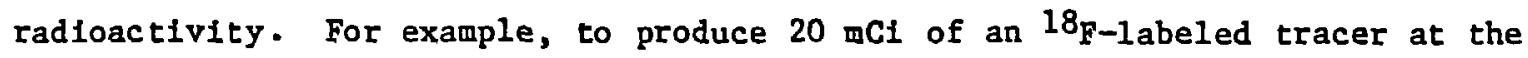
end of a 60 min synthesis requires starting with $\sim 300 \mathrm{mCl}$ of 18 F if the radiochemical yield is $10 \%$. Since this quantity of $18_{\mathrm{F}}$ as a point source delivers $0.45 \mathrm{mR} / \mathrm{sec}$ at $1 \mathrm{~cm}$, heav1ly shlelded work areas and an experinental setup which is compatible with such a shielded work area are essential features of the process. Thus the technical aspects of refining the experimental design of the synthetic approach so that the labeling can be accomplished reliably and remotely becomes 1mportant at this stage of the development of the radiotracer.

Experimental Design - Examples

The integration of an experimental setup into a shielded work area requires defining the essential features of a synthetic approach, incorporating them into an experimental setup which minimizes operator Intervention and discarding nou-essentlul transfers, and intermediate purlfication steps whenever possible. Frequently micro-scale reactions are used and therefore the glassware and other components of the synthesis system must be designed and fabricated on a micro-scale to minimize losses which occur on transfer and manipulation. This has been accomplished by different groups using different approaches (99,185, 211, 230,345,405,494-496). Frequently the designation of essential vs. non-essentlal steps in a procedure requires a cossiderable amount of experimental work. Colncident with this streaslining process, yleld improvements are usually made because the procedure is mede faster by eliminating cumbersome transfers and manipulations. The goal in the setup of a routine system is the evolution of the sinplest possible experimental system which involves a minumum number of manipulations. This sequence can then be automated or integrated into a manual/recote system or an automatic/remote system, using extension tools and/or manipulators and remotely controlled valves. One concept which can be applied to all experimental approaches is that all components of the system which do not come into contact with the radioactivity or where low levels of radioactivity is involved be set up outside of the shielded area.

To illustrate the different approaches to carrying out the routine synthesis zemotely, examples of the experimental design and procedures for 


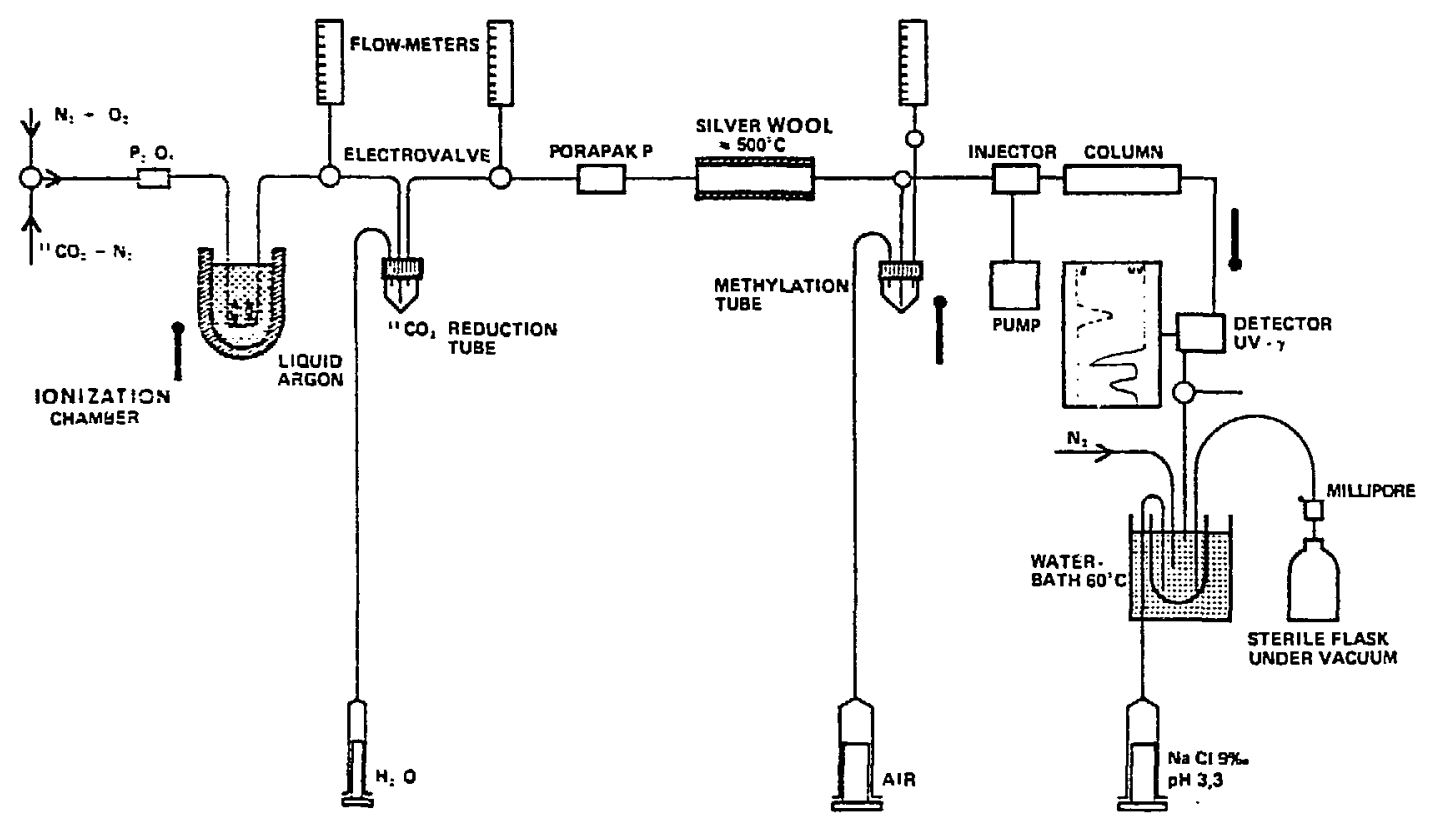

Fig. 4 Experimental setup for ${ }^{11} \mathrm{C}$-imipramine synthesis (photograph provided by $D$. Comar). 
producing positron emitting radiotracers which are routinely used are presented. These tracers are ${ }^{1 l_{C}} \mathrm{C}$-labeled imipramine, ${ }^{1 l_{C}} \mathrm{C}$-labeled palmitic acid and 18F-2-deoxy-2-fluoro-D-glucose and demand for them at the institution where they were developed as well as at collaborating institutions has necessitated devising the shielded experimental setups for thelr frequent and routine production. Further increases in demand for short-lived radiotracers w11l require more sophisticated approaches. For example, the concept of programmable unit process automation which consists of a central processing unit (computer) which senses certain experimental parameters, regulated events related to these paraneters and logs events for future reference would possess distinct advantages over the hard-wire automated systems which are in use today. For example, changes could be effected by reprograming rather than rewiring and individual programs could be generalized and applied to any number of production and synthesis systems. Thus total automation of all aspects of short-lived radlotracer synthesis for routlve use is a goal which should free scientists for creative efforts in the deveiopment of new radiotracers for application in blology and mediclne.

11C-Inipramine (185): A schematic diagram of the synthesis apparatus is shown in figure 4. It is housed in the closed shlelded hood shown in figure 3C. Carbon-11 labeled $\mathrm{CO}_{2}$ produced by the Irradiation of a static nitrogen target ${ }^{14} \mathrm{~N}(\mathrm{p}, \alpha)^{11_{C}}$ is purged with a stream of nitrogen through a $\mathrm{P}_{2} \mathrm{O}_{5}$ trap to remove water and trapped in a metal capillary at $-185^{\circ} \mathrm{C}$ (ARCON). The trap is warmed to $20^{\circ} \mathrm{C}$ and the $11^{1} \mathrm{CO}_{2}$ is purged (carrter gas: $\mathrm{N}_{2}+2 \% \mathrm{O}_{2}$ ) through a soiution of $50 \mu 1$ of ThF (anhyd) and 4-8 $\mu$ mol of $\mathrm{LiAlH}_{4}$ at $-5^{\circ}$ to - $10^{\circ}$. The THE is evaporated by heating the tube at $130^{\circ}$, while bubbling a current of attrogen, then cooled and $50 \mu 1$ of water 1 added. ${ }^{11} \mathrm{C}$-labeled methanol is distilled off by heating the vessel to $130^{\circ}$ and is carried through a Porapale $P$ trap size $(0.3 \times 10 \mathrm{~cm})$ to remove THF and through a silver wool. furnace $\left(0.3 \mathrm{x} 7 \mathrm{ca}\right.$ ) at about $500^{\circ}$ to give ${ }^{11_{C}} \mathrm{C}$-formaldehyde.

The ${ }^{1 l_{C}}$-5orwaldehyde 1 purged through a solution of 1 umol of norimipramine (PERTOFRAR) $1 \mu$ mol $\mathrm{NaCNBH}_{3}, 2 \mu \mathrm{l}$ of acetlc acid, $50 \mu \mathrm{l}$ of $\mathrm{H}_{2} \mathrm{O}$ and $200 \mu \mathrm{H}$ acetonitrile and the mixture $1 \mathrm{~s}$ heated to $50^{\circ}$ for $7 \mathrm{~min}$.

The mixture is then injected into a $50 \mathrm{~cm}$ Partisil Magnum 9 column eluting with a rixture of $97 \%$ chloroform, $3 \%$ ethanol (containing $2 \%$ ethylamine and $2 \%$ water). The fraction contalning the appropriate chromatogram peak is collected in a heated container and the solvent (5-10 ml) evaporated by a strean of nitrogen. The labeled product is redissolved in $5 \mathrm{ml}$ of physiological serum buffered to $\mathrm{pH} 3.3$ by sodfum phosphate $\left(2.5 \times 10^{-3} \mathrm{M}\right)$, 


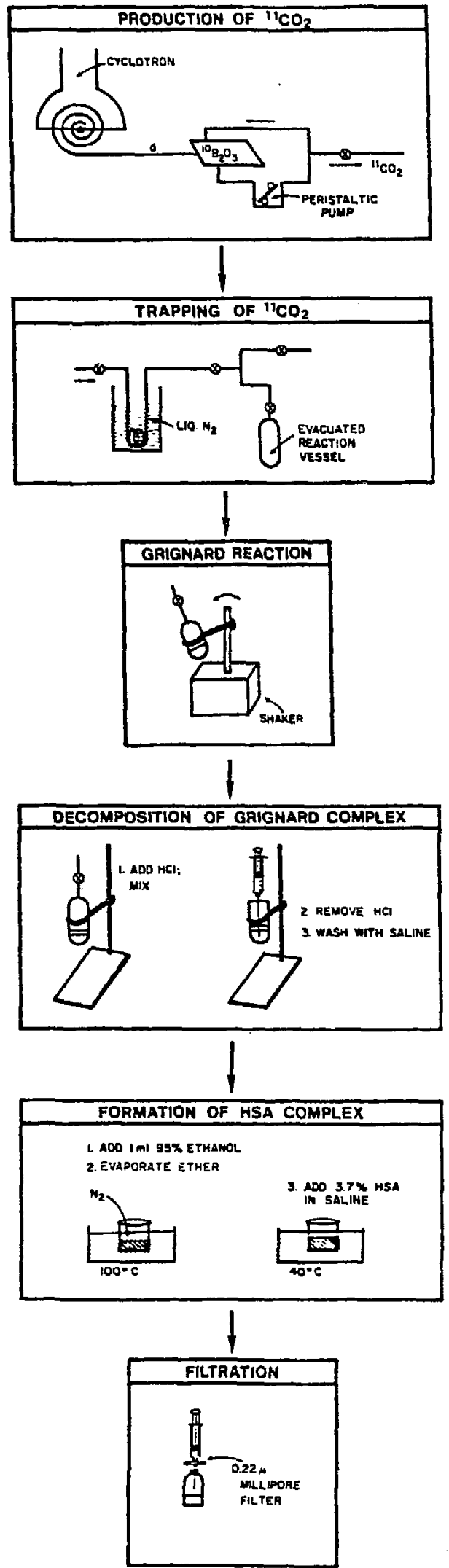

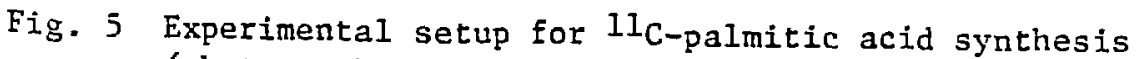
(photograph provided by K. McElvaney and M. Welch). 
followed by sterilization by filtration through a $0.22 \mu \mathrm{m}$ Milipore filter connected by a sterile needle to an evacuated sterile vial.

This method results in the preparation of $50-80 \mathrm{mCl}{ }^{11_{C}} \mathrm{C}$-1mipramine with a specific activity of $\sim 500 \mathrm{mCl} / \mu \mathrm{mol}$ starting with $500 \mathrm{mCl}-1 \mathrm{Cl}$ of $1 \mathrm{CO}_{2}$. The synthesis time is $25 \mathrm{~min}$. The material is chromatographically pure, sterile and apyrogentc. The completely enclosed design results in no radiation risk to personnel involved in the synthesis.

${ }^{11} \mathrm{C}$-Palmitic Ac1d (211): The ${ }^{11} \mathrm{CO}_{2}$ is produced in situ at the Washington Unfversity Medical School Cyclotron (Allis Chalmers) by the ${ }^{10_{B}(d, n)}{ }^{11_{C}}$ reaction. The ${ }^{11} \mathrm{CO}_{2}$ is swept from the target with a carrier gas mixture of helfum:oxygen (98:2), ylelding $>95 \%$ of the 1sotope in the desired ${ }^{11} \mathrm{CO}_{2}$ form. The ${ }^{11} \mathrm{CO}_{2}$ is trapped in a coiled glass tube containing a plug of glass wool and immersed in liquid nitrogen. (See figure 5 for experimental setup).

After warming the trap in a water bath, the ${ }^{11} \mathrm{CO}_{2}$ is quickly transferred to an evacuated vessel using a flow of helium. Two ml of the Grignard solution are added and the vessel is shaken for about 3 to 4 minutes. The palmitic acid-MgBr complex is decomposed with 2 ml of $1 \mathrm{~N}$ HCl while shaking the vessel to clarify the ether layer. The contents are transferred to a $1.5 \times 12 \mathrm{c}=$ test tube, the acidic layer removed by means of a syringe, and ether freed of any traces of acid by washing twice with 2 ml portions of normal saline solution $(0.9 \% \mathrm{NaCl})$. The ethereal solution is then transferred to a $50 \mathrm{mi}$ beaker, $1 \mathrm{ml} \mathrm{95 \%} \mathrm{ethanol} \mathrm{is} \mathrm{added,} \mathrm{and} \mathrm{the} \mathrm{ether} \mathrm{is} \mathrm{evaporated} \mathrm{in} \mathrm{a}$ hot water bath uader $\mathrm{N}_{2}$ to yield a final volume of $\sim 1 \mathrm{ml}$. The resulting solution is warmed to $40^{\circ} \mathrm{C}$ and combined with about $8 \mathrm{ml}$ of $3.7 \%$ human serum albumin in normal saline, also at $40^{\circ} \mathrm{C}$. After warming for about 3 minutes to allow for binding of the palmitic acid to the albumin, the mixture is filtered througin a $0.45 \cup$ Millipore filter, and the filter and beaker are rinsed with $\sim 1 \mathrm{ml}$ of saline. The solution is finally passed through a $0.22 \mathrm{\mu}$ disposable Mflifpore filter and the activity measured prior to infection. The total preparation time, including the initial trapping of ${ }^{11} \mathrm{CO}_{2}$, is about $15-20$ minutes.

In orier to verify the formation of $11_{C}$-palmitic acid and detect any pentadecane or other fopurfties which may be present, the final solution is analyzed by high pressure liquid chromatography under the following conditfons: 


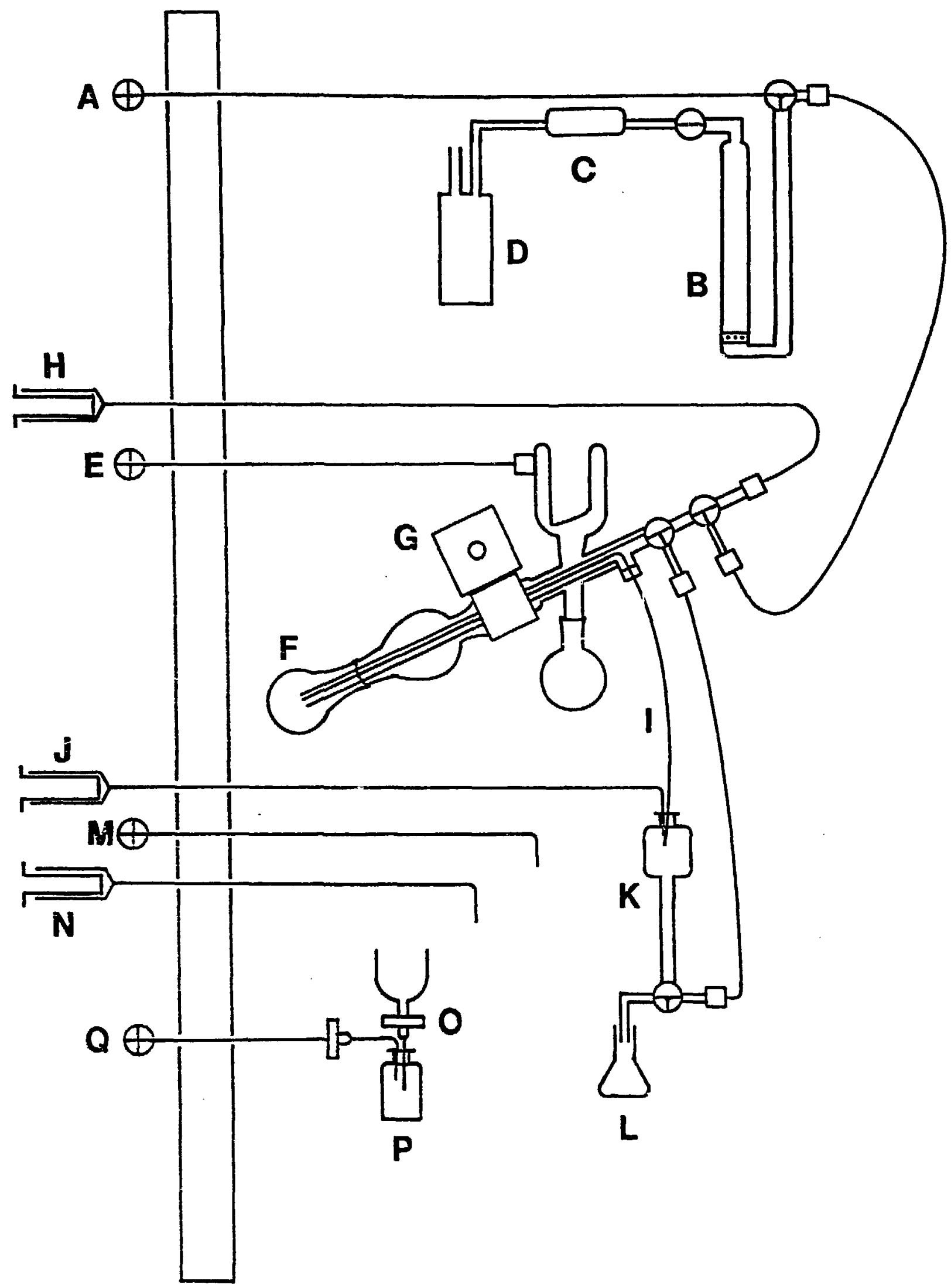

Fig. 6 Experimental setup for 2-deoxy-2[18]fluoro-D-glucose synthesis. 
Instrument: Waters LC; $M-6000$ solvent delivery system

Column: Fatty acld analysis column, 10 micron particle size;

$3.9 \mathrm{~mm}$ I.D. $x 30 \mathrm{~cm}$ long

Solvent: $\mathrm{THF}: \mathrm{CH}_{3} \mathrm{CN}: \mathrm{H}_{2} \mathrm{O}:(35: 30: 40, \mathrm{v}: \mathrm{v})$

Flow Rate: $2 \mathrm{ml} / \mathrm{min}(\sim 2300$ psi)

Refractive Index and $\mathrm{NaI}(\mathrm{T} 1)$ Detectors

${ }^{11} \mathrm{C}$-Palmitic acid elutes at about $5.0 \mathrm{~min}$, and the hydrocarbon at about 10.0 min. Analyses of ${ }^{11} \mathrm{C}$-palmitic acid preparations, as expected, have not shown a mass peak corresponding to the pentadecane, which preclpitates out in the alcoholic solution upon evaporation of ether, and is later filtered out of the final preparation. Radiochromatograms consistently show a single peak with a retention corresponding to that time of unlabeled palmitic acid; the radiochemical purity is calculated to be higher than $99 \%$.

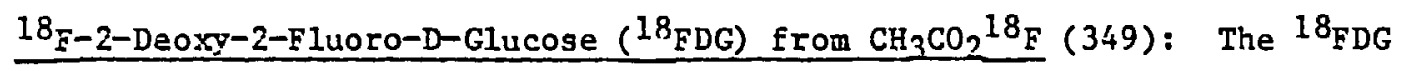
synthesis systen is shown in figure 6 with letters referring to various components. Prior to the run, all of the components are assembled in the shielded synthesis hood (figure 3B) with 1/8" O.D. teflon tubing and Swagelock fittings.

The contents of the irradiated $\mathrm{Ne} / \mathrm{F}_{2}$ target containing $\left[1 \mathrm{~F}_{\mathrm{F}}\right] \mathrm{F}_{2}$ in neon ( 40 umol $\mathrm{F}_{2}$ ) was purged (needle valve A) through a vessel (B) containing a solution of andonium hydroxide $0.010 \mathrm{ml}$ in glacial acetic actd (15 $\mathrm{ml}$ ). The gas exiting the reaction vessel is passed through a soda lime trap (C) and a charcoal (6́-3 mesh) trap (D) at $-73^{\circ} \mathrm{C}$. Purging of the target $(25.5$ ats $\rightarrow 1$ atm) requires 25 minutes after which the acetic acld solution is transferred by vacuug (E) Into the flask (F) of a rotary evaporator (G, Brinkman Hociel M). Flask F contains $25 \mathrm{mg}$ of 3,4,6-tri-0-acetyl glucal (Aldrich Charical Co., no purffication required). After transfer the acetic actd is evaporated to dryness, 3 ml of $2 \mathrm{~N} \mathrm{HCl}$ is added (syringe H) and the mixture heated at $130-135^{\circ} \mathrm{C}$ for $12 \mathrm{~min}$ whtle rotating the flask. Charcoal

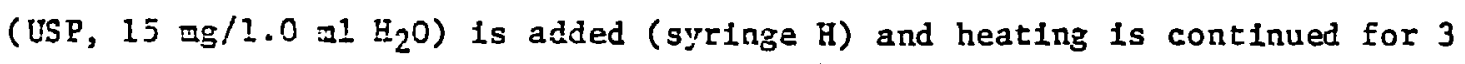
minutes after intich the solution is evaporated to dryness. To the residue is added (syrlinge $\mathrm{E}$ ) $2 \mathrm{ml}$ of aqueous acetonitrile $\left(0.3 \mathrm{ml} \mathrm{H}_{2} \mathrm{O} / 100 \mathrm{ml} \mathrm{CH}_{3} \mathrm{CN}\right.$ ). This is evaporated to dryness, an additional $3 \mathrm{ml}$ of aqueous acetonitrile is adjed and the raixture transferred from flask $F$ via teflon tube (I) and syringe vacuum $(\mathrm{J})$ onto a flask chronatrography culumn $(\mathrm{K}, 0.75 \mathrm{~cm} \times 10 \mathrm{~cm})$ packed dry ith silica gel 60 (Merck No. 9385) and rinsing with 2 ml of the aqueous acetonitrile. Syringe $J$ is then used to apply pressure to the column and force the acetonitrile solution onto the packing after which 20 ar of 
aqueous acetonitrile is added and elution is begun. A forecut (7-8 ml) is collected (L) after which the flow is directed into the rotary evaporator and the remalning solvent is eluted into the rotary evaporator to which a clean flask has been attached. The solvent is evaporated and 1 ml of water 1 added and evaporated. The flask is removed from the evaporator, a stream of nitrogen $(M)$ is firrgut through 1 for 2 min to remove all traces of solvent. Saline $(8 \mathrm{ml})$ is added via syringe $N$ and the solution is passed through a millipore filter 0 into an evacuated (vacuum $Q$ ) multi-injection vial $P$. This procedure typically produces $1.5-2.0 \mathrm{mg}$ of $18_{\mathrm{FDG}}$ in a synthesis time of 70 minutes from EOB. The radiochemical yleld is $20 \%$ and the purity is $97 \%$ as determined by thin layer chromatography. Thus from $350 \mathrm{mCl}$ of $18_{\mathrm{F}}$ one obtains 45 mCl of FDG at end of synthesis (sOS, $70 \mathrm{~min}$ ). 
Appendix 1. A Quide to the Literature of Organic Synthesis

This appendix is intended to serve as a guide to the chemicai literature emphasizing works which are of particular value to designins practical synthetic approaches to organic molecules. The vast body of documentation in organic synthesis appearing in the form of text books, monographs, reviews and journal articles precludes all but a superficlal treatment here. However within the selected references the reader can be guided through many aspects of the designing, refining and implementation of a synthetic approach which is compatible with the restraints imposed by short-lived nuclides. Along these lines the brien description of a selected number of leading works on the following topics will be covered:
A. Searching the literature for a particular organic molecule
3. Works of synthetic organic chemistry
C. Special topics
D. Review articles

A. Searchizg the literature for a particular organic compound:

A search of the literature serves to reveal the preparation, physical and chemical properties, and uses of an organic molecule. Frequently, a number of synthetic routse to the unlabeled molecule can be found in the literature and one or mor $\equiv$ of these can be adapted to the rapid labeling with a positron emitter. The following is suggested as a rapid stepwise approach to searching the linezature.

1. Determine the molecular formula for the compounds, and name the molecule.

2. Locate the formula in Beflstein (described below) and differentiate among structural isomers by the name. References Iisted fn Bailstein (first and second supplenents) cover the literature tirough 1929.

3. Cossult Chemical Abstracts (described below) collective formula injex for the years 1920-1946, and the cumulative indizes for the following fears (1947-1956, 1957-1961, 1962-1966, 1957-1971, 1972-1976) and yearly indices thereafter. Beilstein (in Grran): Although a book has been wrltten on the use of Beilstein (A Bzief Introduction to the Use of Beilstein's Handbuch der Organischen Chemie, E. H. Huntress, John Wiley and Sons, Inc., Ner York, 1938), a brief guide to its uses usually suffices to provide a rapid overview of the literature through 1929. The simplest method involves the use of the cumulative formula indices. The compound is located based on its formula and name, after which will appear volume and page references to the main series 
(the literature through 1909) and the first supplementary serles (1909-1919) and the second supplenentary series (1919-1929). For example, the Beilstein entry in the formula index for formaldehyde (molecular formula $\mathrm{CH}_{2} \mathrm{O}$ ) appears: $\mathrm{CH}_{2} \mathrm{O}$ Formaldehyde 1,558 , I289, II615; 6II 1244.

This refers to volume 1 page 558 of the main series. volume 1 page 289 of the first supplement (Erstes Erganzungswerk) and volume 1 page 615 of the second supplement (Zweites Erganzungwserk) 6II 1244 refers to volume 6 page 1244 of the second supplement

Chemical Abstracts: The American Chemical Society publishes chemical abstracts which summarizes all original articles on chemistry that appear in journals. It is published twice a month. Yearly indices of formulae, authors and subjects appear along with the cumulative indices described above.

B. Works of synthetic Organic Chemistry

D. Barton and W. D. Ollis, Comprehensive Organic Chemistry. The Synthests and Reactions of Organic Compounds, J. F. Stoddard ed., (Pergamon Press, Oxiord, 1979). Six volumes give emphasis to the properties and reactions of all the important classes of organic compounds. Volune 6 is an extensive index according to formula, subject, author, reaction and reagents. The reaction index is especially useful since part of the listings under each reaction fs cojpilation of pertinent references (mainly reviews). The reagent index lises over 2500 organic and inorganic coupounds which are used in organte synthesis and gives specific reactions performed by the reagent followed by a list of compounds which undergo that particular reaction with the reagent. This index is cross referenced with volume 1-5.

Organic Reactions: (John Wiley and Sons, New York) A series of volumes frow 1942 to present containing chapters devoted to specific reactions and contaias experimental procedures and tables detailing every case of use of the reaction at the time of irting.

Hoube-.-Jeg1, "Methoden der Organischen Chemie," E. Muller, ed., Thelme Verlag, 4in E⿺., 1952-present. A compilation of synthetic methods and references, prisarily arranged by functional group including many experimental procedures. In Gezran.

L. F. Fieser and M. Fieser, Reagents for Organic Synthesis, Vol. I-VII, (John Wiley and Sons, Inc., New York) A series of volunes having an alphabetical arrangement of reagents with their synthetic applications. References to original literature and review articles with extensive indices. 
C. A. Buehler and D. E. Pearson, Survey of Organic Syntheses, Second Edition, (W. A. Benjamin Inc., Californla, 1972) A survey of selected synthetic methods including formation of carbon-carbon bonds, reductions and oxidations.

C. Special Topics

J. Mathleu and J. Weill-Raynal, Formation of C-C Bonds (George Thieme Fiblishers, Stuttgard, 1973) in three volumes; contains formula schemes and tables; volume 1 describes reactions which Involve the introduction of one carbon atom bearing a functional group into the carbon skeleton (1.e. hydroxymethylation, the Mannich reaction, formylation, carboxylation and cyanation) and is of particular value to surveying posstble routes for incorporation of one carbon precursors of ${ }^{11_{C}}$ into conplex molecules.

M. R. C. Gerstenberger and A. Haas. Methods of fluorination In organic chemistry. Angew. Chem. Int. Ed. Engl. 20, 647-667, 1981.

Protective Groups in Organic Synthesis T. W. Geene (John Wiley and Sons, He: York, 1931). Th1s book presents Information on the synthetically useful protectize groups ( 500) for five major functional groups: $-\mathrm{OH},-\mathrm{NH}$, $-\mathrm{SH},-\mathrm{CO}_{2} \mathrm{Z}$ and $\mathrm{J}_{\mathrm{C}=0}$. References through 1979, the best method(s) of formaticn and cleavage, and some information on the scope and limitations of each protective group are given.

Frotective Groups in Organic Chemistry J. F. W. McOnie, Ed. (Plenum Press, London, 1973) There is a chapter devoted to each of the functional groups comonly in need of protection. See also Cheristry and Industry (No. 18), Sept. 1979 pp. 603-604 for articles on recent developments on protective groups and E. Haslam, Recent developments in methods for the esterffication and protection of the carboxyl group. Tetrahedron $36,2409-2433,1980$.

W. A. Sieppard and C. M. Sharts, Organic Fluorine Chemistry (W. A. Benjanin, Inc., New York, 1969). A critical look at the literature through 1968 includes discussions of mechanisms, synthetic methods and extensive tables; see also C. M. Sharts and W. A. Sheppard, "Methods to Prepare Yonofluoroaliphetic Compounds", In Organlc Reactions Vol. 21 (John Wiley and Sons, the "ork, 1974) pp. 125-406.

M. Hucilicky, Chemistry of Organic Fluorine Compounds, 2nd edition, (Halsted Press, a Division of John Wiley and Sons, New York, 1976). Contains extensive material on the synthesis and reactions of organic fluorine compounds with extensive references, examples of experimental procedures and techniques for handling fluorination reagents. 
M. F. A. Dove, The Halogens and Hydrogen. Coordination Chemistry Reviews $30,351-378,1979$. A review focussing on recent developments on the synthesis of novel fluorine containing compounds.

R. Rylander, Catalytic Hydrogenation In Organic Syntheses (Academic Press, New York, 1979); a guide to catalyst selection and reaction conditions arranged according to the functional group undergoing reduction.

E. R. H. Walker, The functional group selectivity of complex hydride reducing agents, Chen. Rev. 5, 22-50, 1976.

A. i. Gordon and R. A. Ford, The Chemist's Companion (John Wiley and Sons, Inc., New York, 1972) A handbook of practical data, techniques and references.

IUPAC Conmission on the Nomenclature of Organic Chemistry (CNOC), Nomenclature of Organic Chemlstry Section H: Isctoplcally Modified

Compounds. Eur. J. Biochell. 86, 9-25, 1978.

IUPAC Commission on the Nomenclature of Inorganic Chemistry. Nomenclature of Inorganic Chemistry 12. Isotopically Modified Compounds. Pure and Appl. Chem. 51,1981-1994, 1979. See al so Pure and Appl. Chem. 53, $1887-1900,1981$.

D. Review Articles: Recent indices to review articles on topics related to synthetic methodologg can be rapidly located by consulting the following sources:

D. Barton and W. D. Ollis. Comprehensfive Organic Chemistry. The Synthesis azd Reactions of Organic Compounds (see description above).

J. Org. Cher. 43, 3085, 1978. Recent Reviews 1, covers the 1977 literatuze.

J. Org. Ches. 43, 4397, 1973. Recent Reviews 2, covers the first part of the 1978 11terature.

J. 0rg. Cherl. 44,1752, 1978. Recent Reviews 3, covers the second part of the 1978 literature.

J. Org. Che: $44,4016,1979$. RecentReviews 4, covers the first part of the 1979 literature.

J. Or言. Chem. 45, 1728, 1980. Recent Reviews 5, covers the second half of the 1979 literature.

Index of Biochenical Reviews, 1980 (complled by R. E. Arnstein, M. Harvey and H. R. V. Arnsteln, FEBS Letters, 131, Supp1., August, 1981. 
Appendix 2. A Quide to the Literature on Organic Synthesis with Isotopes Especially Positron Emitters.

General References

A. Murray and D. L. Williams, Organic Synthesis with Isotopes, Parts I and II (Interscience Publishers, Inc., New York, 1958). An encyclopedic source of methods of 1sotopic synthesis with detalled experimental procedures covering the literature through 1955 . The synthetic routes used for the preparation of ${ }^{14} \mathrm{C}$-labeled compounds may, In some cases be generalized to ${ }^{11_{C}}$ keeping in mind the significant differences between labeling with ${ }^{14} \mathrm{C}$ and ${ }^{11_{C}}$.

H. E. Mertel, "Sgathesis of Isotopically labeled Compounds" in Drug Fate and Metabolism, Vol. 3, E. R. Garrett and J. L. Hirtz (Marcel Dekker, Inc., New York, 1979). This chapter includes sections on synthetic and analytical methods.

D. R. Christman and K. I. Karlstrom, Accelerator Produced Nuclides for Use In Biology and Medicine - A Bibllography, Vol. I (1939-1973) and Vol. II (January 1974 - June 1976) (Brookhaven National Laboratory, Associated Unfversities Inc., BNL No. 50448). This blbliography focusses on charged particle accelerators, their use for nuclide production, the synthesis of compounds $f$ n research and application in nuclear medicine; includes subject, nuclide and author indices.

A. P. Wolf, D. R. Christman, J. S. Fowler and R. M. Lambrecht, "Synthesis of Radlopharmaceuticals and Labeled Compounds Utilizing Short Lived Isotopes" In Radiopharisaceuticals and Labelled Compounds, Vol. I, (IAEA, Vienna (1973), IAEA-SM-171/30) p. 345 .

N. D. Heindel, H. D. Burns, T. Honda and L. W. Brady, eds. The Chemistry of Radiophareazieuticals (Hasson Publishing U.S.A., Inc., 1978) Contalns chapters or Iajlopharmaceutical design, quality control and positron emftting radiophergeceuticais.

J. C. Clark and P. D. Buckingham, Short-Lived Radioactive Gases for Clinical Use (Butterworths, London and Boston, 1975). A practical handbook concerned with the production of short-lived radioactive gases $\left({ }^{11} \mathrm{C},{ }^{13_{\mathrm{N}}}\right.$, $\left.15_{0}\right)$.

D. J. Silvester, Preparation of Radiopharmaceuticals and Labeled Compounds lising Short-Lived Radionuclides, Radiochrmistry, Vol. 3, The Cherica: Society, Burlington House, London, 1976, p. 73-107.

L. Kronrad, K. Mudra and J. Marek, Preparation of Organic Compounds Labeled with Short-Lived Radiolsotopes, Radiolsotopy, 17, p. 155-249, 1976. 
G. Subramantan, B. A. Rhodes, J. F. Cooper and V. J. Sodd, Eds., Radiopharmaceuticals, Proceedings of the First International Symposium on Radiopharmaceuticals, (The Soclety of Nuclear Medicine, Inc., New York, 1975). Contains chapters on the halogens, cyclotron products and quality control.

J. A. Sorenson, book coordinator, Radiopharmaceuticals II, Proceedings of the 2nd International Symposium on Radiopharmaceuticals, (The Society of Nuclear Medicine Inc., New York, 1975). Contalns chapters on organic radiopharmaceuticals and radionuclide production.

J. Root and K. Krohn, editors, Short-Lived Radionuclides in Chemistry and Biology. A. C. S. Advances in Chemistry Series Monograph, American Chemical Soclety, Washington, D. C., 1981. Contains sections on Nitrogen-13, Carbon-11 and Fluorine-18 Radiobiochemistry.

A. P. Woli, Chalrman, First International Symposium on Radiopharaaceucleal Chemistry, Journal of Labelled Compounds and Radiopharmaceuticals 13, No. 2, 155-290 (1977). Detailed abstracts of papers.

M. J. Welcia, Chairman. Third International Symposium on

Radiopharaceutical Chemistry. Journal of Labelled Compounds and Radiopharmaceuticals 18, Nos. 1 and 2, 1-286, 1981. Detalled abstracts of papers .

D. J. Silvester, Chairman, Second International Symposium on Radlopharaaceutical Chemistry, Journal of Labelled Compounds and Radiopharmaceucicals 16 , No. 1, 1-233 (1979). Detalled abstracts of papers.

In adicton, the International Journal of Applied Radiation and Isotopes, Vol. 28 (Nos. 1 and 2), 1977 devoted a special issue to Radiopharmaceutical and Other Compounds Labeled with Short-Lived Radionuclides. The following articles are of interest:

M. G. Stzaatmann, "A look at ${ }^{13} \mathrm{~N}$ and $15^{0}$ in radiopharmaceuticals," p. $21-24$.

A. P. Wolf and C. S. Redvanly, "Carbon-11 and Radfopharmaceuticals," pp. 2s-48.

C. Mazarazo, M. Maziere, G. Berger and D. Comar, "Syntnesis of methyl iodide-il $C$ and formaldehyde- ${ }^{1 l_{C}}$, pp. 49-52.

A. J. Palmer, J. C. Clark and R. W. Gulding, "The preparation of fluorine-18 labeled radiopharmaceuticals," pp. 53-55.

X. A. Krohn and A. L. Janshali, "Radiocheuical quality control of short-lived radiopharmaceuticals," pp. 213-227. 
Journals (covering varlous aspects of radlotracer development)

Journal of Labelled Compounds and Radlopharmaceuticals (Vol. XVII (No. 4) is a compound index for Vol. I-XVI).

International Journal of Applied Radiation and Isotopes

Journal of Ralloanalytical Chemistry

Journal of Nuclear Mediclne

International Journal of Nuclear Medicine and Blology

Radfochinica Acta

Semlnars in Nuclear Medicine

European Journal of Nuclear Medictne

Nuclearmedizin 


\section{B IBLIO GRAPHY}

1 Wolf AP. Special characteristics and potential for radiopharmaceuticals for positron emission tomography. Sem. Nucl. Med. XI, 2-12, 1981.

2 Ter-Pogossian M, Raichle ME and Sobel BE. Postitron-emission tomography. Sci. Am. 243, 170-181, 1980 .

3 Raichle ME. Quantitative in vivo autoradlography with positron emission tomography. Bralin Res. Rev. 1, 47-68, 1979.

4 Ter-Pogossian M. Special characteristics and potential for dynamic function studies with PET. Sem. Nucl. Med. XI, 13-23, 1981.

5 Fowler IS and Wolf AP. Special characteristics and potential for radiotracers for positron emission tomography. Acupuncture and Electrotherapeutics Research - The International Journal $\underline{6}, 81-105,1981$.

6 Browne11 GL, Budinger TF, Lauterbur PC, et al. Positron tomography and nuclear magnetic resonance lmaging. Sclence 215, 619-626, 1982.

7 Reivich $M$, Kuh1. D, Wolf AP, et al. The [18F]fluorodeoxy-glucose method for the meesurement of local cerebral glucose utilization in man. Circ. Res. 44, 127-137, 1979.

8 Phelps $\mathrm{ME}$, Euang SC, Hoffman EJ, et al. Tomographic measurement of local glucose netabolic rate in humaus with (F-18)2-fluoro-2-deoxy-D-glucose: validation of method. Ann. Neurol. 6, 371-388, 1979.

9 Huang SC, Phelps ME, Hoffman EJ, et al. Nontnvaslve determination of local cerebral metabolic rate of glucose in man. Am. J. Physiol. 238, (Endocrinol. Metab. 1), E69-E82, 1980.

10 Alayi $A$, Relvich $M$, Greenberg $J$, at al. Mapping functional activity in brain fth 18F-fluoro-deoxyglucose. Sem. Nuc1. Med. XI, 24-31, 1981.

11 Phelps ME, Kuhl DE and Mazzlotta JC. Metabolic mapping of the braln's response to visual stimulation: studies in humans. Science 211, $1445-1443,1981$.

12 Geeniez: JH, Relvich $M$, Alavi A et al. Metabolic mapping of functional activity in human subjects with the [ ${ }^{18} \mathrm{~F}$ ] fluorodecxyglucose techinque. Science $212,678-680,1981$.

13 Phelps $2 \mathrm{E}$. Posttron computed tomography studies of cerebral glucose metabolisa in man: theory and application in nuclear medicine. Sem. Nucl. Me. XI, 32-49, 1981.

14 Farkas $T$, Relvich $M$, Alavi A, et al. The application of [18 F]-2-deoxy-2-fluoro-D-gluco e and positron emission tomography in the study of psychlatric conditions. In Cerebral Metabolism and Neural Function, editors, J. V. Passonneau, R. A. Hawkins, W. D. Lust and F. A. Welsh, William and Wilkins, Baltimore/London, 1980, pp. 403-408. 
15 Ferris SH, deleon MJ, wolf AP et al. Positron emission tomography in the study of aging and senile dementia. Neuroblology of Aging 1, 127-131, 1980.

16 Kellersohn $C$. Positron-emitting radionuclides in the study of metabolic and physiopathologic mechanisms. Brit. J. Radio1. 54, 91-102, 1981.

17 Comar D, Zarifian E, Verhas $M$ et al. Brain distribution and kinetics of $11 \mathrm{C}$-chlorpromazine in schizophrenics: positron emission tomography studies. Psychiatry Res. 1, 23-29, 1979.

18 Schelbert HR, Henze $E$ and Phelps ME. Emission tomography of the heart. Sem. Nucl. Med. $x, 355-373,1980$.

19 Brownell GL, Correla JA, Zamenhof RG. Positron instrumentation. Recent Advances in Nuclear Medicine, Vol. 5, T. F. Budinger, ed., New York, Grune and Strattoa, 1978.

20 Ter-Pogossian MM. Basle Princlples of computed axial tomography. Sem. Nuc1. Med. VII, 109-127, 1977.

21 Phelps $\mathrm{KE}$. Emission computed tonography. Sem. Nucl. Med. $\underline{7}, 337-365$, 1977.

22 Budinger TE, Gullberg GT, Huesman RH. Emission computed tomography. Topics Appl. Physics 32, 147-246, 1979.

23 Sokoloff $\mathrm{I}$. Mapping of local cerebral functional activity by measurement of local cerebral glucose utilization with [ $\left.{ }^{14} \mathrm{C}\right]$ deoxyglucose. Brain 102, 653-668, 1979.

24 Konfg E. Pharmaceutical chemistry today - changes, problens and opportunities. Ang. Chemle. Int. Ed. Engl. 19, 749-761, 1980.

25 Counsell $R E$ and Ice $R D$. The design of organ Imaging radiopharmaceuticals in "Drug Design", Vo1. VI, Chapter 4, E. J. Ariens (ed.), Academic Press, New York, 1975.

26 Heindel ND. Princlples of target tissue localization of radiopharmaceuticals. in The Chemlstry of Radiopharmaceuticals, N. D. Heindel, H. D. Burns, T. Honda and L. Brady, eds., Masson Publishłng USA., Inc., New York, 1973, p. 1i-33.

27 Burns ED. Design of Radiopharmaceuticals. In The Chemistry of Radfopharmaceuticals, N. D. Helndel, H. D. Burns, T. Honda and L. Brady, eds., Massun Publisining USA, Inc., New York, 1978, p. 35-51.

28 Eckelman WC and Reba RC. The classification of radiotracers. J. Nucl. Med. 19, 1179-1181, 1978.

29 Taylor DM. Biochemfcal aspects of radiopharmaceutical design. J. Lab. Compnds. and Radlopharm. XVI, 1-3, 1979 (Abstr.).

30 Colombetti G. Principles of Radiopharmacology, Vol. 1-III, CRC Press, Inc., Boca Raton, Florida, 1979. 
31 Lien EJ. Structure-absorption-distribution relationships: Significance for drug design. In Drug Design (E. J. Artens, ed.) Academic Press, New York, 1975, Volume V, Chapter 3, pp. 81-132.

32 Hansch $C$. On the structure of medicinal chemistry: J. Med. Chem. 19, $1-6,1976$.

33 Hansch C. A quantitative approach to blochemical structure-activity relationships. Accts. Chern. res. 2, 232-239, 1969.

34 Gallagher, BM, Fowler JS, MacGregor RR et al. In vivo measurement of transport and metabolic processes using radiotracers in. Principles of Radipharmacology Vol II, L. G. Columbetti, ed., CRC Press, Inc., Boca Raton, Florida, 1979, p. 135-154.

35 Meyer MC and Guttman DE. The binding of drugs by plasma proteins. J. Pharm. Sci. 57, 895-918, 1968.

36 Anton $\mathrm{AB}$ and Solamon HM, editors. Drug protein binding. Annals of $\mathrm{N}$. Y. Acad. Sci. 226, 5-362, 1973.

37 Dayton PG, Israilf $\mathrm{ZH}$ and Perel JM. Influence of binding on drug getabolism and distribution. Ann. N. Y. Acad. Sci. 226, 172-194, 1973.

38 Koch-Weser $J$ and Sellers EM. Binding of drugs to serum albumin, (Parts 1 and 2), New England Journal of Medicine 294, 311-316 and 526-531, 1976.

39 Bickel MAl and Gerny R. Drug distribution as a function of binding coapetition. Experiments with the distribution dialysis technique. J. Pharin. Pharmacol. 32, 669-674, 1980.

40 Anderson $\mathrm{WW}$, Orton TC, Pickett RD, et al. Accumulation of amines in the 1solated perfused rabbit lung. J. Pharmacul. Exp. Ther. 189, 456-466, 1974 .

41 Fowler JS, Gallagher BM, MacGregor RR, et al. Carbon-11 labeled alipinatic amines in lung uptake and metabolism studies: potential for dynamic measurements in vivo. J. Pharmacol. Exp. Ther. 198, 133-145, 1976.

42 Brown EAI. The localization, metabolism and effects of drugs and toxicants in the lung. Drug Metab. Rev. 3, 33-87, 1974.

43 Gillis $\mathrm{CN}$. The metabolism of vasoactive hormones by lung. Anesthesfology 39, 626-632, 1973.

44 Anderson JH, Anderson RC and Iben LS. Hepatir uptake and propranolol, J. Pharaacol. Exp. Ther. 206, 172-180, 1978.

45 Willians RT, Milburn P, Swith RL. The Influence of enterohepatic circulation on toxicity of drugs. Ann. N. Y. Acad. Sc1. 123, 110-140, 1965. 
46 Fichtl B, Bondy B, and Kurz H. Binding of drugs to muscle tissue: dependence on drug con: intration and lipid content of tissue. J. Pharmacol. Exp. Ther. 215, 248-253, 1980.

47 Eckelman WC, Reba RC, Gibson RE, et al. Receptor binding radlotracers. A class of potential radiopharmaceuticals. J. Nucl. Med. 20, 350-357, 1979.

48 Katzenellenbogen JA, Heiman DF, Lloyd JE, et al. In vitro binding assays as a guide for optimization of the structure of steroid receptor-binding radiopharmaceuticals: estimation of receptor vs. non-receptor binding. J. Label Cmpnds. Radiopharm. XVIII, 85-87, 1981 (Abstr.).

49 Vera DR, Thomas AJ, Schelbe PO, et al. Identifiability of kinetic models for in vivo receptor systems. J. Label. Copnds. Radiopharm. XVIII, 88-90, 1981) (Abstr.).

50 Eckelman WC, Gibson RE, Rzeszotarski WC, et al. The design of receptor binding radiopharmaceuticals. J. Lab. Copnds and Radiopharm. XVI, 4-5, 1.979 (Abstr.).

51 Krohn KA. The search for a gamma-emltting estrogenlc ligand. J. Nucl. Med. 21, 593-595, 1980 (Teaching Editorial).

52 Conar D, Berger G, Crouzel C, et al. Carbon-11 labeled radiopharaaceuticals for brain receptor studies. T. Label. Conds. Radiophar. IVIII, 3-4, 1981. (Abstr.)

53 Levia VA. Relationship of octanol/water partition coefficlent and molecular weight to rat brain capillary permeability. J. Med. Chem. 23, $682-684,1980$.

54 Oldezdozi wh and Dewhurst WG. The Blood-Brain Barrler and Psychotropic Drugs $t 2$ Principles of Psychopharmacology, Academic Press, Inc., New York, $\leq 978$, pp. 183-191.

55 Cotsias GC, Teng LC and Ginos JZ. Monoamine oxidase and cerebral uptake of doparizerglc drugs, Proc. Nat1. Acad. Sc1. U.S.A., 71, 2715-2719, 1974 .

56 Loberz MD. Radiotracers for cerebral functional imaging-a new class J. Nic1. Med. $\underline{21}, 183-186,1980$ (Teaching Editorial).

57 Rapoport SI. Blood-brain barrier In "Physlology and Mediclne", New York, Raven Press, 1976.

58 Hardejo JE, Emson PC, Falck B, et al. Enzymes related to monoamine transalter metabolism in brain microvessels. J. Neurochem. 35, 1388-1393, 1980.

59 Loberg MD, Corder EH, Fields AT, et al. Membrane transport of Tc-99m-labeled radlopharmaceuticals. 1. Braln uptake by passtve transport. J. Nucl. Med. 20, 1181-1188, 1979. 
60 Bradbury $M$. The concept of a blood-brain barrier. John Wiley and Sons, New York, 1979.

61 Hardebo JE and N11sson B. Estimation of cerebral extraction of circulating compounds by the brain uptake index method: influence of circulation time, volume injection, and cerebral blood flow. Acta Phystol. Scand. 107, 153-159, 1979.

62 Pardridge WM and oldendorf WH. Transport of metabolic substrates through the blood-brain barrfer. J. Neurochem. $\underline{28}, 5-12,1977$.

63 Kung HF and Blau M. Regional Intracellular pH shift: A new mechanism for radiopharmaceutical uptake in brain and other tissues. J. Nucl. Med. 21, 147-152, 1980.

64 Carter CC, Lifton JF and Welch MJ. Organ uptake and blood $\mathrm{pH}$ and concentration effects of ammonia in dogs determmined with ammonia labeled with 10 minute half-11ved nitrogen-13. Neurology 23, 204-213, 1973.

65 Kaufman JJ, Semo $\mathrm{NM}$ and Koski WS. Microelectrometric titration measurement of pKa's and partition and drug distribution coefificlents of narcotics and narcotic antagonists and their $\mathrm{pH}$ and tempera:ure dependence. J. Med. Chem. 18, 647-655, 1975.

66 Ra11 DP, Stabenau JR and Zubrod CG. Distribution of drugs between blood and cerebrospinal fluid: general methodology and effect of $\mathrm{pH}$ gradient. J. Pharmacol. Exp. Ther. 125, 185-193, 1959.

67 Yatvin $\mathbb{S B}$, Kreutz $W$, Borwitz $B$, et al. Induced drug release from lipld vesicles 1 n serum by pH-change. Biophys. Struct. Mech. $\underline{6}, 233-234,1980$.

68 Purceil $\mathrm{wP}$, Bass GE and Clayton JM. Experinental detemaination of partition coefficients. In Strategy of Drug Design: A gulde to Biologica? Activity, John Wiley and Sons, Ner York, 1973, p. 126-143.

69 Beierwaltes WH, Wieland DM and Swanson DP. Radiolabeled enzyme Inhibitors for imaging in Principles of Rujiopharmacology, Vol. II, I. G. Colunbett1, ed., CRC Press, Inc., Boca Raton, Florida, 1979, p. 41-57.

70 Brodbeck U. Recent developments in the field of enzyme inhibitors. Chimia 3L, 415-421, 1980.

71 Gibson RE, Eckelman WC, Rzeszotarski NJ, et al. Radiotracer localizatton by receptor-11gand interactions, in Principles of Radiopharmacolopy, Vol. II, L. G. Columbett, ed., CRC Press, Inc., Boca Ratou, Florida, 1979 , p. 17-39.

72 Gallagher BM, Ansari A, Atkins $H$, et al. Radiopharmaceuticals XXVII,

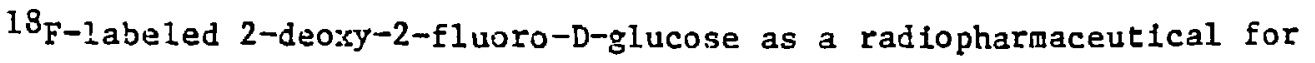
measuring reglonal myocardial glucose aetabolisn in vivo: tissue distribution and inazing studies in aninals. J. Nuc. Med. 18, 990-996, 1977. 
73 Gallagher BM, Fowler JS, Qutterson NI, et al. Metabolic trapplng as a principle of radiopharmaceutical design: some factors responsible for

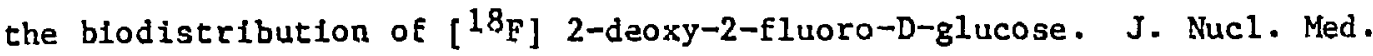
19, $1154-1161,1978$.

74 Hnatowich DJ and Clancy B. Investigations of a new, highly negative liposome with Improved biodistribution for Imaging. J. Nucl. Med. 21, $662-669,1980$.

75 Juliano RL and Stamp D. The affect of particle size and charge on the clearance rates of $\mathrm{i}$ Iposomes and liposome encapsulated drugs. Blochem. Blophys. Res. Commun, 63, 651-658, 1975.

if Caride VJ and Zaret BL. Liposome accumulation in regions of experimental myocardial infarction. Science 198, 735-738, 1977.

77 A series of papers under the general title "Chemical Aspects of Pro-Drug Design" was published in Chemistry and Industry, 7 June 1980, p. 433-461.

78 Stella VJ and Himmelsteln $\mathrm{KJ}$. Prodrugs and site specific drug delivery. J. Med. Chem. 23, 1275-1282, 1980.

79 Bessell EM, Foster $A B$, Westwood JH. The use of deoxyfluoro-Dglucoppranoses and related compounds in a study of jeast hexokinase spectfictty. 3iochem. J. 128, 199-204, 1972.

80 Machado de Donenech EE and Sols A. Specificlty of hexokinases towards some uncongon substrates and inhibitors. FEBS Letters 119, 174-176, 1980.

81 Sols $A$ and Crane RK. Substrate spectfity of brain hexokinase. J. Blol. Crem. 210, 581-595, 1954.

82 Tilbury RS and Laughlin JS. Cyclotron production of radioactive lsotopes for nedical use. Seminars in Nuclear Mediclne 4, 245-255, 1974.

83 Wolf AP. Medical cyclotrons, In Medical Radlonuclide Imaglng, Vol. 1, IAEA, Vienna, 1977, p. 343-355.

84 Ruth T.J and Wolf AP. "Small" accelerator, radionuclide and radiopharmaceutical production. IEEE Trans. Nucl. Sci. 1710-1712, 1979.

85 Silyester DJ and Waters SL. Radionuclide Production. in Radiopharazeeuticals II. New York, Soclety of Nuclear Medicine, 1979, p. $727-744$.

86 Silvester DJ. Accalerator production of medically useful radionuclides, In Radiopharmaceuticals and Labeled Compounds, Vol. 1, IAEA, Vienna, 1973, p. 197-222.

87 Welch $W$, TerPogossian MM. Preparation of short half-lived radioactive gases for nedical studies. Radiat. Res. 36, 580-587, 1968. 
88 Clark JC, Buckingham PD. The preparation and storage of carbon-11 labeled gases for clinical use. Int. J. App1. Radiat. Isot. 22, 639-646, 1971.

89 Christman DR, Finn RD, Karlstrom $\mathrm{K}$, et al. The production of ultra high activity ${ }^{11} \mathrm{C}$-labeled hydrogen cyanlde, carbon dloxide, carbon monoxide and methane via the ${ }^{14} \mathrm{~N}(\mathrm{p}, \alpha){ }^{11} \mathrm{C}$ reaction $(\mathrm{XV})$. Int. J. Appl. Radiat. isot. 26, 435-442, 1975.

90 Christman DR, Finn RD, Karlstroin K, et al. Production of carrier-firee $\mathrm{H}^{11} \mathrm{CN}$ for medical use and radiopharmaceutical syntheses. II. J. Nucl. Med. 14, 864-866, 1973.

91 Finn RD, Christman DR, Ache HJ, et al. The preparation of cyanide-11 $C$ for use in the synthesis of organic radiopharmaceuticals. II. Int. J. Appl. Radiat. Isot. 22, 735-744, 1971.

92 Lamb JF, James RW, Winchell HS. Recoll synthesis of high speciflc

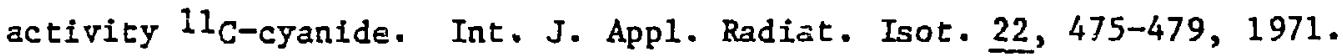

93 Rossler $\mathrm{K}$, Vogt $M$, Stocklin G. Production of ${ }^{11_{C}} \mathrm{C}$-precursors via the ${ }^{14} \mathrm{~N}(\mathrm{~F}, \mathrm{C})^{11_{C}}$ reaction in solid ammontum halides at higher doses. $\mathrm{J}$. Label. Cipds. Radlopharm. XVIII, 190, 1981 (Abstr.).

94 Iwata R, Ido T, Tomlnaga T. 11 -guanidine - a new precursor proluced by proton isradiation of liquid ammonia. J. Label. Copds. Radlopharm. XIIII, 187-188, 1981. (Abstr.).

95 Iwata $R$, Ido $T$, Tominaga $T$. The production of ${ }^{11_{C}} \mathrm{C}$-guanidine by the proton Irradiation of the liquid amonia-nitrous oxide system and Its use in the synthesis of ${ }^{11} \mathrm{C}$-pyrimidines. Int. J. Appl. Radiat. Isot. 32 , $303-308,1981$.

96 Wagner R, Stocklin G, Schaack $W$. Production of carbon-11 labeled methyl lodide by direct recoll syothesis. J. Label. Compds. Radiopharm. XVIII, 1557-1566, 1981 .

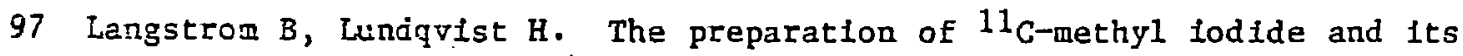
use in the synthesis of ${ }^{i}$ C-methyl-L-methionine. Int. J. Appl. Radiat. Isot. 27, 357-363, 1976.

98 Marazano C, Maziere $M$, Berger $G$, et al. Synthesis of methyl fodide- ${ }^{1} 1_{C}$ and Enzmaldehyde-11C. Int. $j$. Appl. Radiat. Isot. 28, 49-52, 1977.

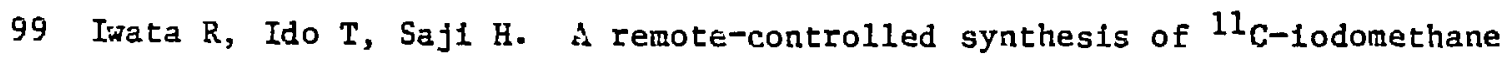
for the practical preparation of carbon-11 labeled radiopharmaceuticals. Int. J. App.l. Radiat. Isot. 30, 194-196, 1979.

100 Christman DR, Crawford EJ, Frledkin M, et al. Detection of DNA synthes1s

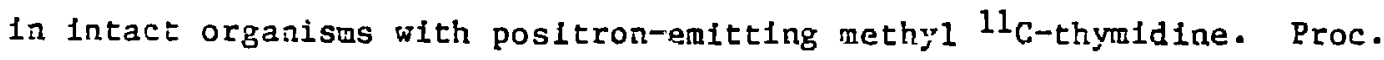
Nat. Acad. Sci. USA 09, 988-992, 1971. 
101 Berger G, Mazlere M, Sastre J, et al. Carrier-free ${ }^{11}$ C-formaldehyde: an approach. J. Label. Capds. Radiopharm. XVII, 59-T1, 1980.

102 Reiffers $S$, Vaalburg $W$, Wefgman $T$, et al. Carbon-11 labeled methyllithium as methyl donating agent: the addition to 17-keto steroids. Int. I. Appl. Radiat. Isot. 34, 535-539, 1980.

103 Winstead $M$, Chern $C-I$, Lin $T-H$, et al. Synthesis and preliminary scintigraphic evaluation of in vivo distribution of ${ }^{11_{C}} \mathrm{C}$-hydroxyurea/

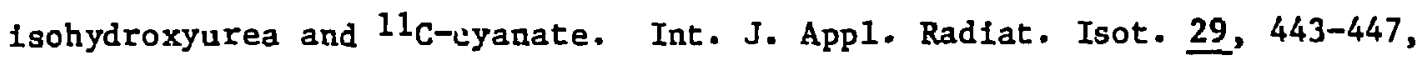
1978.

104 Roeda D, Crouzel C, van Zanten B. The production of ${ }^{11}$ C-phosgene without added carrier. Radiochem. Radloanal. Lett. 33, 175-178, 1978.

105 Roeda D, Westera G. A novel methed for the production of ${ }^{11} \mathrm{C}$-phosgene. Its use in the preparation of ${ }^{1 I_{C}}$-labeled ethyl chloroformate, diethyl carbonate, diphenylurea, 5,5-diethyl barbiturate, 5,5-ethylphenyl barbiturate, ethylphenyl hydantoin and diphenyl hydantoin. J. Label. Copds. Rad1opharu. XVIII, 11-12, 1981 (Abstr.).

106 Brinkan GA, Hass-Lisewska $T$, Veenboer JT, et al. Preparation of ${ }^{1} 1_{\mathrm{COCl}} 2_{2}$. Int. J. Appl. Radiat. Isot. 29, 701-702, 1978.

107 Roeda D, van Zanten B. Production of ${ }^{11} \mathrm{C}$-labeled phosgene. J. Label. Cmpds. Radiopharm. XIII, 284, 1977 (Abstr.).

108 Christman DR, Finn R, Wolf AP. A novel synthesis of carbon-11 labeled phosgene. 10th Int. Hot Atom Symposium. Longhborough, Eng. 1979 (Abstr.).

109 Roeda D and Westera G. A UV-Induced on-line synthesis of ${ }^{1} \mathrm{C}$-phosgene and the preparation of seme of its derivatives. Int. J. Appl. Radiat. Isot. 32, 931-932, 1981 .

110 Myers WG. 11C-Acetylene. J. Nucl. Med. 13, 699-701, 1972.

111 Cramer RD, Kistiakowsky GB. The synthesis of radioactive lactic acid. J. Biol. Cher. 137, 549-555, 1941.

112 Vaalburg $W$, Reiffers S, Beerling E, et al. The preparation of carbon-11 labeled 17a-ethynylestradiol. J. Label. Cmpds. Radiopharn. 13, 200-201, 1977 (Abstr.).

113 Hickles RJ, Gatley SJ, Madsen MT, et al. High yield synthesis of the sequence ${ }^{13} \mathrm{~N}_{2}, 13_{\mathrm{N}_{2} \mathrm{O}},{ }^{11} \mathrm{C}_{2} \mathrm{H}_{2}, \mathrm{H}_{2}{ }^{15} \mathrm{O}, \mathrm{H}_{2}{ }^{14} \mathrm{O}$ and $17 \mathrm{~F}^{-}$for rCBF studies. J. Label. Capds. Radiopharm. XVI, 90-91, 1979 (Abstr.).

114 Crouzel C, Sejourne $C$, Comar D. Production of $11_{C}$-acetylene by methane pyrolysis. Int. J. Appl. Radiat. Isot. 30, 566-568, 1979.

115 Machulla HJ, Laufer P, Stocklin G. Radioanalytical quality control of ${ }^{11} \mathrm{C},{ }^{18} \mathrm{~F}$ and ${ }^{123} \mathrm{I}-1$ abeled compounds and radiopharmaceuticals. $\mathrm{J}$. Radioanal. Chen. 32, 381-400, 1976. 
116 Tilbury RS, Dahl JR, Mamacos JP, et al. Fluorine-18 production for medical use by helium-3 bombardment of water. Int. J. Appl. Radiat. Isot. 21, 277-281, 1970.

117 Clark JC, Silvester DJ. A cyclotron method for the production of fluorine-18. Int. J. Appl. Radiat. Isot. 17, 151-154, 1966.

118 Welch MJ, Lifton JF, Gaspar PP. Production of $18_{\mathrm{F}}$ for bone scanning from the ${ }^{20} \mathrm{Ne}(d, \alpha)^{18} \mathrm{~F}$ reaction via fluorine-18 labeled nitrosyl fiuoride. A selecilve fluorlnating agent. J. Nucl. Med. 12, 405, 1971 (Abstr.).

119 Harper PV, Lembares N, Krizek H. Production of $18 \mathrm{~F}$ with deuterons on neon. J. Nucl. Med. 12, 362-363, 1971 (Abstr.).

120 Elmaleh DR, Hnatowitch DJ, Cochavi S, et al. Emission tomographic Images of the skull with fluorine-18. Int. J. Nucl. Med. B1ol. 7, 289-293, 1980.

121 Nozaki $T$, Tanaka $Y$, Shimamura $A$, et al. The preparation of anhydrous $\mathrm{H}^{18} \mathrm{~F}$. Int. J. Appl. Radiat. Isot. 19, 27-32, 1968.

122 Crouzel C, Comar D. Production of carrier-free 18F-hydrofluoric acid. Int. J. Appl. Radiat. Isot. 29, 407-408, 1978.

123 Ehrenkaufer RLE, Fowler JS, MacGregor RR, et al. Production of carrler-free, anhydrous $\mathrm{B}^{18} \mathrm{~F}$ by deuteron irradiation of $\mathrm{H}_{2} / \mathrm{Ne}$ target gas. Part 1, 2nd Chemical Congress of North American Continent, San Francisco, Cal., 1980. ISBNO-8412-0583-3. (Abstr.).

124 Tewson TJ, Welch MJ and Raichle ME. [18 ${ }^{18}$-labeled 3-deoxy-3-fluoroD-glucose: syathesis and preliminary biodistribution data. J. Nucl. Med. 19, 1339-1345, 1978.

125 Lambrecht RM, Nelrinckx R, Wolf AP. Cyclotron Isotopes and Radiopharmaceuticals - XXIII. Novel anhydrous ${ }^{18}$ F-fluorinating internediates. Int. J. Appl. Radiat. Isot. 29, 175-183, 1978.

126 Dahl JR, Lee $R$, Schmall B, et al. A novel target for the preparation of anhydrous $18_{\mathrm{F}}$ with no added carrier. J. Label. Compds. Radiopharm. XVIII, 34-35, 1991 (Abstr.).

127 Winchell AS, Wells DK, Lamb JF. Fluorine-18. U.S. Patent 3,981,769, 1976. (Cher. Abstr. 85, 590, 1976).

128 Straataran MG, Welch MJ. Fluorine-18-labeled diethylamino sulfur trifluoride (DAST): An $F$ for $O H$ fluorlnating agent. J. Nucl. Med. 18, $151-158,1977$ (DAST).

129 Winchell HS, Wells $\mathrm{kK}$, Lamb JF, et al. Fluorlne-18. Gov. Offen. 2, 321, 552, 1973 (Chern. Abstr. 80, 33089r, 1974).

130 Casella $V$, Ido $T$, Wolf AP, et al. Anhydrous F-18 labeled elemental fluorine for radiopharmaceutical preparation. J. Nucl. Med. 21, 750-757, 1980 . 
131 Bida GT, Ehrenkaufer RL, Wolf AP, et al. The effect of target-gas purity on the chemical form of F-18 during $18_{\mathrm{F}-\mathrm{F}_{2}}$ production using the neon/Fluorine target. J. Nucl. Med. 21, 758-762, 1980.

132 Lambrecht RM, Wolf AP. Cylcotron and short-lived halogen isotopes for radiopharmaceutical applications. "Radiopharmaceuticals and Labeled Compounds", Vol. 1, IAEA, IAEA-SM-171/94, 1973, Vienna, p. 275-290.

133 Ido $T$. Synthesis and In vivo distribution patterns of $19_{F}$-organic compounds. Proc. First World Congress Nuclear Medicine World Federation of Nuclear Medicine and Blology, p. 901-903, 1974.

134 Nozaki $T$, Fukushi $K$, Irie $T$. On some radlohalogen derivatives of cholesterol. J. Label. Compds. Radiopharm. XIII, 226, 1977 (Abstr.).

$13 j$ Gnade BE, Schwaiger GP, Llotta CL, et al. Preparation of reactorproduced carrier-free ${ }^{18} 8_{\mathrm{F}}$-fluoride as the potassium 18-crown-6-complex for syathesis of labeled organic compounds. Int. J. Appl. Radiat. Isot. 32, 91-95, 1981 .

136 Clark JC, Goulding RW, Roman M, et al. The preparation of fluorine-18 labeled compounds using a recirculatory neon target. Radiochem. Radioanal. Lett. 14, 101-108, 1973.

137 Nozaki $T$, Iwamoto $M$, Ido $T$. Yleld of $18_{F}$ for various reactions from oxygen and neon. Int. J. Appl. Radiat. Isot. 25, 393-399, 1974.

138 Ebrenkaufer $R$ and MacGregor RR, private communication.

139 Fowier, JS, Shiue, CY, Wolf, AP, et al. Syrthesis of $18_{F-1 \text { abeled acetyl }}$ hypofluorite for radlotracer synthesis. Manuscript in preparation.

140 Yagi $M$, Amano R. Production of $18_{F}$ by means of photonuclear reactions and preparation of anhydrous $\mathrm{H}^{18} \mathrm{~F}$. Int. J. Appl. Radiat. Isot. 31 , $559-551,1980$.

141 Neirinckx RD, Lambrecht RM, Wolf AP. Cyclotron 1sotopes and

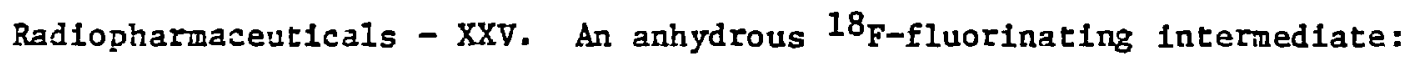
Trifluoromethyl hypofluorite. Int. J. Appl. Radiat. Isot. 29, 323-327, 1978.

142 Lambrecht RM, Mantescu C, Fowler JS, et al. Novel $18_{F}$ intermed lates for the synthesis of radiopharmaceuticals. J. Nucl. Med. 13, 785-786, 1972. (Abstr.).

143 Schrobtlgen G, Fiznau G, Chirakal $R$, et al. Synthesis of $\left[{ }^{18_{F}}\right] \mathrm{XeF}_{2}$, a

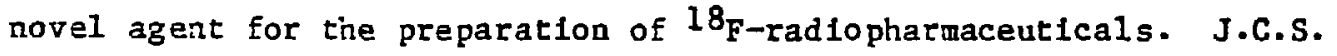
Chem. Comm. 198-199, 1981.

144 Adloff JP, Schlteffer JJ. Retention of fluorlne-18 produced by the $19 \mathrm{~F}(\mathrm{n}, 2 \mathrm{n})$ reaction in solid $\mathrm{XeF}_{2}$ and $\mathrm{XeF}_{4}$. Inorg. Nucl. Cher. Lett. 4 , 403-405, 1958 . 
145 Rrohn YA, Parks NJ. Radiochemistry of nucleogenic $N-13$ in aqueous solutions. J. Label. Compds. Radiopharm. XVI, 87-89, 1979 (Abstr.).

146 Krizek $\mathrm{H}$, Lembares N, Dinwoodie R, et al. Production of radiochemically pure ${ }^{13} \mathrm{NH}_{3}$ for blomedical studies using the ${ }^{16} \mathrm{O}(\mathrm{p}, \alpha)^{13} \mathrm{~N}$ reaction. $\mathrm{J}$. Nucl. Med. 14, 629-630, 1973 (Abstr.).

147 Gersberg R, Krohn $\mathrm{K}$, Peek $\mathrm{N}$, et al. Denttrification studies with $13_{\mathrm{N}}$ labeled nitrate. Sclence 192, 1229-1231, 1976.

148 Witter JP, Gatley SJ, Balish E. Distribution of Nitrogen-13 from labeled nitrate $\left(13 \mathrm{NO}_{3}{ }^{-}\right)$in humans and rats. Science $204,411-413,1979$.

149 Parks NJ, Krohn KA. The synthesis of $13_{\mathrm{N}}$ labeled amimonia, dinitrogen, nitrite and nitrate using a single cyclotron target system. Int. J. Appl. Radiat. Isot. 29, 754-756, 1978.

150 Welch $M$, Lifton $J F$. The fate of nitrogen-13 formed by the ${ }^{12} \mathrm{C}(\mathrm{d}, \mathrm{n})^{13} \mathrm{~N}$ reaction in Inorganic carbides. J. Amer. Chem. Soc. 93, 3385-3388, 1971.

151 Tilbury RS, Dahl JR, Monahan WG, et al. The production of $13 \mathrm{~N}$-1abeled amnonie For medical use. Radiochem. Radioanal. Lett. $\underline{8}, 317-323,1971$.

152 Straatman MG, Welch MJ. Enzymatic synthesis of nitrogen-13 labeled amino acids. Radiat. Res. 56, 48-56, 1973.

153 Ido T, Iwata R. Fully automated synthesis of $13_{\mathrm{NH}_{3}}$. J. Label . Cropds. Rad1opharm. XVIII, 244-246, 1981 (Abstr.).

154 Gelbard AS, Clarke LP, MacDonald JM, et al. Enzymatic synthesis and organ distribution studies with ${ }^{13} \mathrm{~N}$-labeled L-glutanine and L-glutamic ac1d. kadiology 116, 127-132, 1975.

155 Slegers G, Vandecasteele C, Sambre J. Cyclotron production of

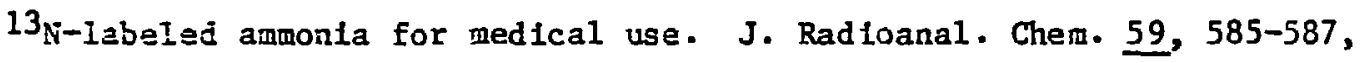
1980.

156 Vaalbuzg $W$, Ramphuis JAA, Reerling-van der Molen HD, et al. An Improved method For the cyclotron production of $13 \mathrm{~N}$ labeled amnonia. Int. $\mathrm{J}$. Appl. Rediat. Isot. 26, 316-318, 1975.

157 MacDonald NS, Cook JS, Birdsall RL, et al. Nitrogen-13 labelled ammonia for miltiple dally needs in a nuclear medicine clinic. Proceedings of the 27th Conf. on Remote Systems Technology, 1979, p. 314-315.

158 Pettit WA, Mortara RH, DIgenis GA, et al. Preparation of nitroso-13 $\mathrm{N}$-labeled nitrosoureas. J. Med. Chem. 18, 1029-1031, 1975.

159 Pettit WA, Tilbury RS, DIgenis GA, et al. A convenlent synthesis of 13 NT-3CNU. J. Label. Compds. Radicpharm. XIII, 119-122, 1977.

160 MicElfresh $\mathrm{NW}$, Meeks JC, Parks NJ. The synthesis of $13 \mathrm{~N}$-labeled nitrite of high speciflc activity and purity. J. Radioanal. Chem. 53, 337-344, 1979 . 
161 Pettit WA. Cherical considerations in the accelerator production of N-13: N-13-nitrosourea preparation. IEEE Transactions on Nuclear Sclence, Vol. NS-26, 1718-1720, 1979.

162 Nickles RJ, Gatley SJ, Hichwa RD, et al. The synthesis of $13 \mathrm{~N}$-1abeled nitrous oxide. Int. J. Appl. Radiat. Isot. 29, 225-227, 1978.

163 Jones SC, Bucelewicz WM, Brisette RA, et al. Production of $13_{\mathrm{N} \text {-molecular }}$ nitrogen for pulmonary positron scintigraphy. Int. J. Appl. Radiat. Isot. $28,25-28,1977$.

164 Wolf AP, Redvanly CS. Carbon-11 and Radiopharmaceuticals. Int. J. App1. Radiat. Isot. 28, 29-48, 1977.

165 Palmer AJ, Clark JC, Goulding RW. The preparation of fluorine-18 labeled radiopharmaceuticals. Int. J. Appl. Radlat. Isot. 28, 53-65, 1977.

166 Robinson GD. Prospects for $18_{F}$ radiopharmaceuticals. Radiopharazeuticals, G. Subramantan, B. A. Rhodes, J. F. Cooper and V. J. Sodd, eds, 'The Society of Nuclear Medicine, Inc., New York, 1975, p. 141-148.

167 Wlafield JM. Preparation and use of 18-fluorine labeled inorganic compounds. J. Fluorine Chem. 16, 1-17, 1980.

168 Straatman MG. A look at $13 \mathrm{~N}$ and 150 in radiopharmaceuticals. Int. J. App 1. Radiat. Isot. 28, 13-20, 1977.

169 Tilbury Rs. "The chemical form of $\mathrm{N}-13$ produced in vartous nuclear reactlous and chemical environnents - a review." in Short-Lived Radionuclides in Chemistry and Blology, J. Root and K. Krohn, eds., A.C.S. Adrances in Chemistry Serles Monograph, American chemical Society, Washington, D.C. 1981.

170 Wolf AP, Christman DR, Fowler JS, et al. Synthesis of railopharmaceuticals and labeled compounds using short-lived isotopes in Radfopharzaceuticals and Labeled Compounds Vol. 1, (IAEA, Vienna (1973), $I A E A-S Y(-171 / 30)$, P. 345 .

171 Vaalburg 7, Strating J, Woldring MG, et a1. Rapid synthesis of $\alpha$-phenyigiyclae by carboxylation of $\alpha$-lithiobenzylisocyanide. Syn. Corin. 2, 423-425, 1972.

172 Vaalburz $\ddot{i}$. Cyclotroa produced short lived isotopes in nuclear medicine 81 pp. Thesis. Ryksunwersiteit, Gronigen, Netherlands (1974).

173 Vaalburg $W$, Beerling-van der Molen HD, Woldring MG. Evaluation of carbon-11 labeled phenylglycine and phenylalanine for pancreas scintigraphy. Nuklearnedizin 14,60-66, 1975.

174 Vaalburg $W$, Beerling-van der Molen HP et al. Preparation of carbon-11 labeled phenylalantne and pnenylglycine by $a$ new amino acid synthesis. J. App1. Radiat. Isot. 27, 153-157, 1976. 
175 Washburn LC, Sun TT, Byrd BL et al. "High-level production of c-11-carboxyl-labeled amino acids." in Radiopharmaceuticals II.

Proceedings of the 2nd International Symposium on Radiopharmaceuticals, (The Sosiety of Nuclear Medicine Inc., New York, 1975), p. 767-777.

176 Digenis GA, Casey DL, Wesner DA, et al. Preparation of optically active C-11-amino acids. J. Nuc1. Med. 20, 662, 1979 (Abstr.).

177 Reiffers S, Beerling-van der Molen HD, Vaaburg $W$, et al. Rapid synthesis and purification of carbon-11 labeled DOPA: a potential agent for brain studies. Int. J. Appl. Radiat. Isot. 28, 955-958, 1977.

178 Langstrom $B$ and Stridberg $B$. Syntheses of racemic $\left[1-1 C_{C}\right]$ alanine and partially resolved [3-11 C] alanine. Int. J. Appl. Radiat. Isotopes 30 , 151-153, 1979.

179 Machulla HJ, Dutschka K. Carbon-11 labeled radiopharmaceuticals: Synthesis and high-pressure liquid chromatography of a-alanine-1-11C. Radiochem. Radioanal. Lett. 25, 309-316, 1976.

180 Harper PV, Wu J, Lathrop KA, et al. On the mechanism of alanine localization in ti.e heart and pancreas. J. Nucl. Med. 21, P77, 1980 (Abstr.).

181 Cohen MB, Spolter L, Chang CC, et al. Enzymatic synthesis of C-11 pyruvic acid, lactic acid and L-alanfne. J. Label. Cmpds. Radiopharm. XVI, 63-65, 1979 (Abstr.).

182 Cohen MB, Spolter L, Chang CC, et al. Enzymatic synthesis of C-11 pyruvic acid, lactic acid, and L-alanine. J. Nucl. Med. 19, 701, 1978 (Abstr.).

183 Kloster $G$ and Laufer $P$. Enzymatic synthesis and chromatographic purification of $\mathrm{L}-3-\left[{ }^{11} \mathrm{C}\right]-1$ actic acld via $\mathrm{D}, \mathrm{L}-3-\left[{ }^{11} \mathrm{C}\right]$-alanine. J. Label. Mupds. Radiopharm. XVII, 889-894, 1980.

184 Comar D, Cartron JC, Maziere M, et al. Labeling and metabolism of methionine-methyl-11C. Eur. J. Nucl. Med. 1, 11-14, 1976.

185 Berger $G$, Mazlere $M$, Knlpper $R$, et al. Automated synthesis of carbon-11 labeled radiopharuaceuticals: imipramine, chlorpromazine, nicotine and methlonire. Int. J. Appl. Radiat. Isot. 30, 393-399, 1979.

186 Syrota $A$, Comar $D$, Cerf $M$, et al. $\left[{ }^{11} C\right.$ ]Methionine pancreatic scanning with fositron enission computed tomography. J. Nucl. Med. 20, 778-781, 1979 .

187 Weimer K. Development of fast syntheses of amino acids and fatty alcohols labeled with carbon-11. Dissertation, Univ. Darmstadt, Germany, 1973.

188 Elias $A$, Latterhos $\mathrm{HF}$, Weimer $\mathrm{K}$. Notiz uber die schnelle syntheses von (3-1 ${ }^{C}$ ) B-alanin. Chem. Ber. 105, 3754-3756, 1972. 
189 Hayes RL, Washburn LC, Wleland BW, et al. Carboxyl-labeled

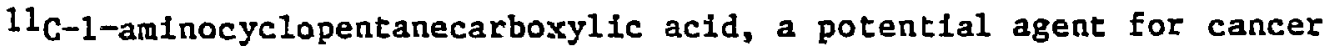
detection. J. Nucl. Med. 17, 748-751, 1976.

190 Hayes RL, Washburn LC, Wleland BW, et al. Synthesis and purffication of ${ }^{11}$ C-carboxyl-labeled amino acids. Int. J. Appl. Radiat. Isot. 29, $186-187,1978$.

191 Hubner KF, Andrews GA, Washburn L, et al. Tumor locat1on with 1-aninocyclopentane [ ${ }^{i l_{C}}$ ] carboxylic acid: preliminary clinical trials with single-photon detection. J. Nucl. Med. 18, 1215-1221, 1977.

192 Washburn LC, Sun TT, Byrd BL, et al. 1-Aminocyclobutane [ ${ }^{1 l_{C}}$ ] carboxylic acid, a potentlal tumor-seeking agert. J. Nucl. Med. 20, 1055-1061, 1979.

193 Washburn LC, Ringenberg RE, Sun TT, et al. ${ }^{11}$ C-Labeled 1-aminocyclohexanecarboxyllc acid ( ${ }^{11} \mathrm{C}-\mathrm{ACHC}$ ), a potenlal agent for studies of amino acid transport in the brain. $\because$. Label. Copds. Radiopharm. XVIII, 13-14, 1981 (Abstr.).

194 Davis, JW. Studies with amino acids. 1. Synthesis of valine. J. Org. Chen. 43, 3980-3982, 1978.

194a Washbura LC, Wieland BW, Sun TT, et al. [1-11 C] DL-Valine, a potential pancreas-imaging agent. J. Nucl. Med. 19, 77-83, 1978.

195 Wasibura LC, Sun TT, Byrd BL, et al. Production of L-[1-11 C]valine by HPLC resolutlon. J. Nucl. Med. 23, 29-33, 1982.

196 Washbura IC, Sun TT, Byrd BL, et al. DL-[carboxy1-11 C] tryptophan, a potential agent for pancreatic imaging; production and preclinical Investigations. J. Nucl. Med. 20, 857-864, 1979.

197 Zalutsky $M$, Wu J, Wlckland $T$, et al. C-11 tryptophan: synthesls and purification using high pressure liquid chromatography. J. Nucl. Med. 20, 663, 1979 (Abstr.).

198 Wu JHC, Harper PV, Lathrop KA. Separation of racemic tryptophan. J. Nuc1. Med. 22, 74, 1981. (Abstr.).

199 Hara $T$, Taylor $C$, Lembares $N$, et al. L-aspartic acid-4-11 $C$ as a tumor scanning agent. J. Nuc1. Med. 12, 361-362, 1971.

200 Barrio JR, Egbert JE, Eenze $A$ et al. L-[4-11 C]Aspartic Ac1d: enzymatic synthesis, myocardial uptake and metabolism. J. Med. Cher. 25, 93-96, 1982.

201 Cohen MB, Spolter L, Chang C, et al. Cl1n. Nucl. Med. S15, 1980 (Abstr.).

202 Dunzendorfer U, Schmall B, Bigler RE, et al. Synthesis and body distr1bution of alpha-aminolsobutyric acid-L-11 $\mathrm{C}$ in normal and prostate cancerbearing rat after chemotherapy. Eur. J. Nuc1. Med. 6 , 535-538, 1981. 
203 Winstead MD, Chern C-I, L1u T-H, et al. Synthesis and preliminary scintigraphic evaluation of in vivo distribution of $11_{C}$-lactle acid and

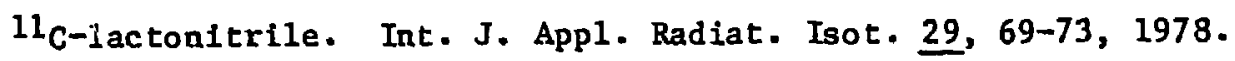

204 Vennesland B, Solomon AK, Buchanan JM, et al. Metabolism of lactic acid contalning radioactive carbon in the $\alpha$ or $B$ position. J. Biol. Chem. 142, 371--377, 1942.

205 Cohen MB, Spolter L, Chang CC, et al. Enzymatic synthesis of $11_{C-p y r u v i c}$ acid and 1i.C-L-lactic acid. Int. J. App. Radiat. Isot. 31, 45-49, 1980.

206 Machulla HJ, Dutschka K. 11C-Labelled radiopharmaceuticals: synthesis and high pressure liquid chromatography of nicotinic-11 $\mathrm{C}$ acid amide. $\mathrm{J}$. Label. Compds. Radiopharm. XVI, 287-293, 1979.

207 Machulla EJ, Laufer P, Stocklin G. 11C-Labeled radiopharaaceuticals: Synthesis and high pressure liquid chromatography of nicotinic ${ }^{1 l_{C}}$-acid. Radiochem. Radioanal. Lett 18, 275-280, 1974.

208 Welch $\mathrm{MJ}$. The role of the chemist in nuclear medicine. In Year Book of Nuclear Medicine, Vol 4., J. L. Quinn III, ed., Year Book Medical Publishers Inc., Chicago, 1969, pp. 6-18.

209 Klein MS, Goldsteln RA, Welch MJ, et a1. External assessment of myocardial metabolism with $\left[{ }^{1 l_{C}}\right.$ ] palmitate 1 rabbit hearts. Am. J. Physiol 237, H51-H57, 1979.

210 Machulla E-J, Stocklin G, Kupfernagel Ch, et al = Comparative evaluation of fatty acids labeled with C-11, C\&-34m, Br-77 and I-123 for metabolic studies of the myocardium: conclse communication. J. Nucl. Med. 19, 298-302, 1978.

211 Welch MJ, Wittmer SL, Dence CS, et al. "Radiopharmaceuticals labeled with ${ }^{11_{C}}$ and ${ }^{18_{F}}$ : considerations related to the preparation of 11C-palmitate." In Short-Lived Radionuclides in Chemistry and Blology, J. Root and K. Krohn, eds., A.C.S. Advances in Chemlstry Serles Monograph, American Chemlcal Soclety, Washington, D.C. 1981.

212 Poe ND, Robinson GD, MacDonald NS. Myocardial extraction of variously labeled Fatty acids and carboxylates. J. Nucl. Med. 14, 440, 1973 (Abstr.).

213 Livni $\Sigma$, Elmaleh DR, Levy $S$, et al. Beta-methyl[1-11 $C$ ] heptadecanolc acid: a new myocardial metabolic tracer for positron enission tomography. J. Nucl. Med. 23, 169-175, 1982.

214 Kutzman $R$, Meyer $G$, Wolf AP, manuscript in preparation.

215 Spolter L, Chang CC, Bobinet D, et al. Enzymatic synthesis of C-11 citric acid. J. Nucl. Med. 17, 558, 1976 (Abstr.).

216 Winstead MB, Lamb JF, Winchell HS. Relationship of chemlcal structure to in vivo seintigraphic distribution pattern of $11_{C}$ compounds: 1. 11C-carboxylates. J. Nucl. Med. 14, 747-754, 1973. 
217 Kamen MD. Radioactive Tracers in Biology, 2nd edition, Academic Press, New York, 1951, pp. 224-243.

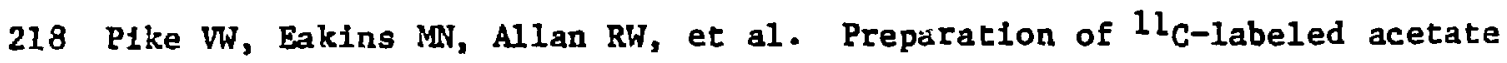
for the study of myocardial metabolism by emission computerized axial tomography. J. Label. Cmpds. Radiopharm. XVIII, 249, 1981 (Abstr.).

219 Nahinsky $P$, Rice $C N$, Ruben $S$, et al. Tracer studies with radioactive carbon. The synthesis and oxidation of several three carbon acids. J. Amer. Chem. Soc. 64, 2299-2302, 1942.

220 Straatman MG, Hortmann AG, Welch MJ. Production of $1{ }^{11}$ C-acetoacetic acid. J. Label. Copds. Rad1opharm. I0, 175-179, 1974.

221 Gatley SJ, Crawford JS, Halama JR, et al. Synthesis of ${ }^{11_{C}} \mathrm{ChI}$ ppuric acid

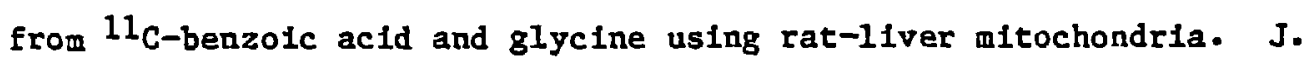
Label. Cmpds. Radiopharm. 16, 182-183, 1979 (Abstr.).

222 Spolter L, Chang CC, Bobinet D, et al. Combined chemical and enzymatic synthesis of C-11 acetyl phosphate. J. Nucl. Med. 16, 572, 1975 (Abstr.).

223 Spolter L, Cohen MB, Chang CC, et al. Enzymatlc synthesis of C-11 acetylcaratine. J. Nucl. Med. 20, 662-663, 1979 (Abstr.).

224 Wisstead MB, Dougherty DA, LIn T-H, et al. Relationship of molecular structure to in vivo scintigraphic distribution of carbon-11-labeled compounds - 4. carbon-11-labeled mandelonitriles, mandelic ac1d, and their esters. J. Med. Chem. 21, 215-217, 1978.

225 Allen $M$ and Ruben S. Tracer studies with radioactive carbon and hydrogen. The synthesis and oxidation of fumaric acid. J. Amer. Chem. Soc. 54, 948-950, 1942.

226 Kloster $G$, Roder E, Machulla HJ. Synthesis, chromatography and tissue

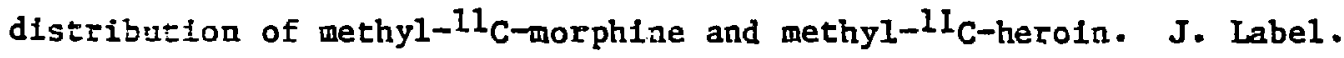
Capds. ReAlopharm. XVI, 441-448, 1979.

227 Allen DR, Beaumier PL. [N-11 $\left.\mathrm{CH}_{3}\right]$-morphine. J. Label Cmpds. Radiophara. XVI, 5I-62, 1979 (Abstr.).

228 Berger $G$, Haziere M, Marazano $C$, et al. Carbon-11 labeling of the psychoacifve drug 0 -gethyl-bufotenine and 1 ts distribution in the animal organism. Eur. J. Nucl. Med. 3, 101-104, 1978.

229 Welch MJ, Coleman RE, Straatmann MG, et al. Carbon-11-labeled methylated polyanine analogs: uptake in prostate and tumor in animal models. J. Nuc1. Med. 18, 74-78, 1977.

230 Berger $G$, Maziere $M$, Comar D. An example of a completely automatic method to synthesize a radiopharmaceutical molecule: ${ }^{11} \mathrm{C}$-imipramine. J. Label. Cmpds. Radiopharm. XVI, 97-99, 1979 (Abstr.). 
231 Comar D, Maziere M, Marazano C, et al. Carbon-11 labeled psychoactive drugs. J. Nucl. Med. 16, 521, 1975 (Abstr.).

232 Mazlere $M$, Berger G, Comar D. ${ }^{11} \mathrm{C}$-Clomipramine: synthesis and analysts. J. Radioanal. Chem. 45, 453-457, 1978.

233 Maztere M, Berger $G$, Comar D. Optimtzaton of ${ }^{11_{C}}$ labeling of

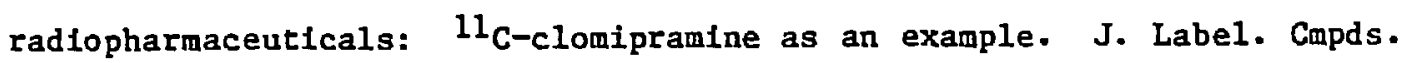
Raciopharm. XIII, 196-197, 1977 (Abstr.).

234 Maziere $M$, Saint-Laudy JL, Crouzel $M$, et al. Synthesis and distribution kinetics of $11_{C}$-chlorpromazine in animals, in Radiopharmaceuticals, $G$. Subramanian, B. Rhodes, J. Cooper, V. Sodd, eds., The Society of Nuclear Medicine, 1975, p. 189-195.

235 Maztere $M$, Godot JM, Berger $G$ et al. 11 C-Labeled etorphine for "In vivo" studies of oplate receptors in brain. J. Radioanal. Cher. 62, 279-284, 1981.

236 Mazlere $M$, Conar D, Marazano $C$ et al. Nicotine-11 C: Synthesis and distribution kinetics in animals. Eur. J. Nucl. Med. 1, 255-258, 1976.

237 Saj1 $\mathrm{H}$, Ido $T$, Iwata $R$, et $a^{i}$. Caffelne- ${ }^{1 l_{C}}$, ephedrine- ${ }^{1 l_{C}}$ and methyl ephedrine-11 C: Synthesis and distribution in mice. Radioisotopes 27 , 451, 1978.

238 Straataan MG, Welch MJ. A general method for labeling proteins with 11 C. J. Nicl. Med. 16, 425-428, 1975.

239 Marche $P$, Marazano $C$, Mazlere $M$, et al. ${ }^{1} 1_{C-1 a b e l i n g}$ of ovine lutelnizing hormone by reductive methylation. Radiochem. Radioanal. Lett. 21, 53-59, 1975.

240 Langstrom B, Sjoberg S, Ragnarsson U. A rapld conventent method for

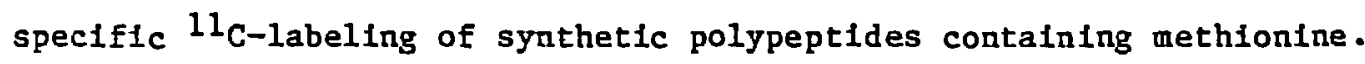
J. Lajel. Coppd. Radlopharm. XVIII, 479-487, 1981.

241 Maziere $M$, Godot JM, Berger G, et al. High specific activity carbon-11-1abeling of benzodlazeplnes: dlazepam and flunttrazepam. J. Radioanal. Chem. 56, 229-235, 1980.

242 Conar D, Maziere $\mathrm{H}$, Godot $\mathrm{N}$, et al. Visualization of ${ }^{11_{C}} \mathrm{C}$-flunitrazepam displacenent in the brain of the live baboon. Nature $280,329-331,1979$.

243 Anwar M, Mock B, Lathrop KA, et al. The locallzaton of carbon-11 labeled hexamethonlun in cartilage. J. Nucl. Med. 18, 638, 1977 (Abstr.)

244 Arwar M, Mock BH, Lathrop KA, et al. The synthesis and development of radloactive quaternary ammonium compounds for in vivo assessment of cart1lage. J. Label. Coupds. Radiophara. XVI, 59-60, 1979 (Abstr.).

244a Pike VW, Palmer AJ, Horlock PL, et al. Preparation of a carbon-11 labeled antiblotic, erythromycin A lactobionate. J. Chem. Soc. Chem. Comm . 173-174, 1982. 
245 Palmer AJ. The preparation of $11_{C}$-methyl labeled 1,1'-dimethy1-4,4'dipyridinium dilodide. J. Label. Cmpds. Radiopharm. XIV, 27-33, 1978.

246 Comar D, Mazlere $M$, Crouzel C. Syntheses et Metabolisme de

L'lodomethylate de chlorpromazine- ${ }^{11} \mathrm{C}$, in "Radlopharmaceuticals and Labeled Compounds", Vol 1, IAEA, IAEA/SM-171/94, Vienna, 1973, p. 461-469.

247 Maziere $M$, Cepeda C, Berger G, et al. ${ }^{11}$ C-Muscarinic antagonist (MQNB) visualizes heart "In vivo" by positron emisston tomography. J. Nucl. Med. 22, 77, 1981. (Abstr.).

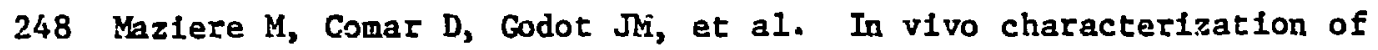
myocardium muscarlaic receptors by positron emission tomography. Life Sc1. 29, 2391-2397, 1981.

249 Maziere $M$, Berger $G$, codot $\mathrm{M}$, et al. ${ }^{11}$ C-Methiodide quinuclindinyl benzilate. A muscarinic antagonist for "in vivo" studies of myocardial muscarinic receptors. J. Radioanal. Chem., in preparation, 1982.

250 Christman DR, Hoyte RM, Wolf AP. Organic radiopharmaceuticals labeled

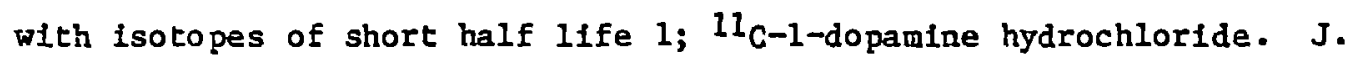
Nucl. Med. 11, 474-478, 1970.

251 Fowler JS, Ansari AN, Atkins HL, et al. Synthesis and preliminary

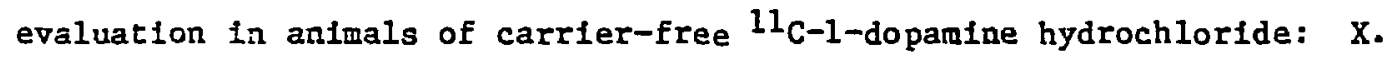
J. Nicl. Yed. $14,867-869,1973$.

252 Fowler JS, Wolf AP, Christman DR, et al. Carrier-free ${ }^{11} \mathrm{C}$-labeled catecholantaes, in Radlopharmaceuticals, G. Subramanian, B. Rhodes, J. Cooper, $\nabla$. Sodd, Eds., Soc. Nucl. Med., Inc., New York, 1975, p.196-204.

253 Fowles JS, MacGegor RR, Ansari AN, et al. Radiopharmaceuticals. 12. A new rapid synthesis of carbon-11 labeled norepinephrine hydrochloride. J. Med. Chen- 17, 246-248, 1974.

254 Forilez JS, Gallagher BM, MacGregor RR, et al. ${ }^{11}$ C-Serotonin: a tracer for the pulzonary endothelial extraction of serotonin. J. Label. Compds. Radiopharm. XIII, 194-195, 1977 (Abstr.).

255 Fowler JS, Gallagher BM, MacGegor RR, et al. Radlopharmaceuticals XIX:

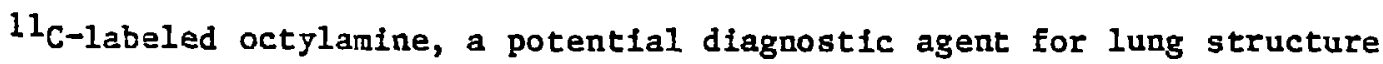
and function. J. Nucl. Med. 17, 752-754, 1976.

256 Washburn LC, Sun TT, Byrd BL, et al. C-ll-Labeled branched-chain amines, potential agents for position tomographic lung function studies. J. Nucl. Med. 21, P13, 1980 (Abstr.). 
257 Winstead $\mathbb{A B}$, Dischino DD, Munder NA, et al. Relationship of molecular structure to in vivo distribution of carbon-1I-labeled compounds. VI. Carbon-11 labeled altphatic diamines. Eur. J. Nucl. Med. 5, 165-169, 1980.

258 Mestelan G, Crouzel C, Comar D. Syuthesis and distribution kinet_es in

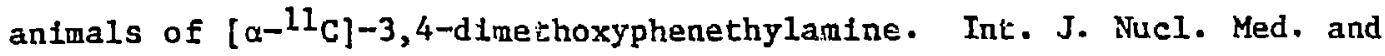
Biol. 4, 185-193, 1977.

259 Jay M, Digenis GA, Chaney JE, et al. Synthesis and brain uptake of carbon-11 phenethylamine. J. Label. Copds. Rad1opharn. XVIII, 237, 1981 (Abstr.).

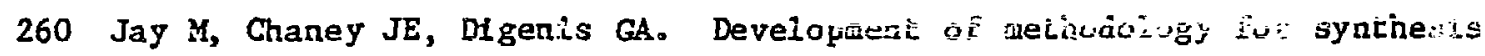
of $[\alpha-C]-l a b e l e d$ phenethylawine. Int. J. Appl. Radiat. Isot. 32 , 345-348, 1981.

261 Fowler JS, MacGregor RR, Wo-i AP, et al. Radiopharmaceuticals. I6. Halogenated dopamine analogs. Synthesis and radiolabeling of 6-iododopanine and tissue distribution studies in animals. J. Med. Chem. 19, 356-360, 1976 .

262 Winstead MB. Dischino DD, Winchell HS. Relationship of molecular structure to the in vivo distribution of carbon-11-labeled compounds. V. Carbon-11-labeled N-alkyl-p-lodobenenesulfonamldes. Nuklearmedizin XVIII, 142-146; 1379.

263 Rafichle $\mathrm{ME}$, Elchling Jo, straatman MG, et aI. Blood-brain barrier permeability of $\mathrm{II}_{\mathrm{C}-\mathrm{label}}$ alcohols and $15 \mathrm{O}$-labeled water. Amer. J. Physiology 230, 543-552, 1976.

264 Robinsou $G D, J r$, MacDonald NS. Blological dynamics of $18_{F}$ and

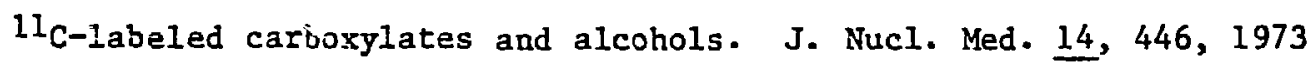
(Abstr.).

265 DeGrazia JA, Rodden AF, Teresi JD, et al. Radioscintigraphic studies of ${ }^{11} \mathrm{C}$ distribution $1 \mathrm{n}$ cats given $1-1{ }^{1} \mathrm{C}$-ethanol. J. Nucl. Med. 16, 73-76, 1975.

266 Palmer AJ, Goulding $\mathrm{RW}$. Biosynthetic preparation of ${ }^{1 l_{C}} \mathrm{C}$-labeled galactose, glycerol and mannitol. J. Label. Crapds. Radiopharm. $\underline{X}$, $627-535,1974$.

267 Wolf AP. The preparation of organic radlopharmaceuticals containing isotopes of short half 11fe. Radiolsotopy $4,499-518,1971$.

268 Lifton $J F$ and Welch $M J$. Preparation of glucose labeled with 20-minute half-lived carbon-11. Radiat. Res. 45, 35-40, 1971.

269 Goulding RH and Palmer AJ. Aspects of the preparation of carbon-11 labeled glucose. Int. J. Appl. Radlat. Isotopes $24,7-12,1973$. 
270 Straatman MG, Welch MJ. The liquid chromatographlc purification of carbon-11 labeled glucose. Int. J. Appl. Radiat. Isot. 24, 234-236, 1973.

271 Ehrin E, Westman E, Nilsson S-O, et al. A convenient method for the

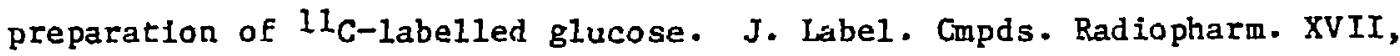
453-461, 1980.

271 a Vyska $K$, Hock $A$, Freundlieb $C$, et al. 3-( $\left.{ }^{11_{C}} \mathrm{C}\right)$-methyl glucose, a promising agent for in vivo assessment of function of myocardial cell nembrane. J. Nucl. Med. 21, P56-P57, 1980 (Abstr.).

272 Kloster G, Muller-Placz $C$, and Laufer $P$. 3-[1]C]-methyl-D-glucose, a potential agent for reglonal cerebral glucose ut1lization studies: Synthesis, cinromatography and tissue distribution in mice. J. Label. Capds. Radiopharm. XVIII, 855-863, 1981.

273 Shiue $C Y$, MacGregor RR, Lade RE, et al. A new synthes is of 2-deoxy-Darabino-hexose. Carbohydrate Res. 74, 323-326, 1979.

274 Mestelan G, Aubert F, Beaucourt JP, et al. Rapid synthesis of $2-d e o x y-D(1-14 C) g l u c o s e$ sultable for labelling with ${ }^{11} \mathrm{C}$. J. Label. Cipds. Radiophara. XVI, 661-668, 1979.

275 Shiue $C-Y$, MacGrezor RR, Lade $R E$, et al. The synthesis of $1-C-11-2-d e o x y-D-g l u c o s e(C-11-2-D G)$ for measuring reglonal brain glucose metabolisa in vivo. J. Nucl. Med. 19, 676-677, 1978 (Abstr.).

276 Fowler JS, Lade RE, MacGregor RR, et al. Agents for the armamentarium of reglonal metabolic measurement in vivo via metabolic trapping: ${ }^{1} l_{C-2-d e o x y-D-g l u c o s e}$ and halogenated deoxyglucose derivatives. J. Label. Cupds. Radiopharm. 16, 7-9, 1979 (Abstr.).

277 MacGregor RR, Fowler JS, Wolf AP et al. A synthesis of $11_{C-2-d e o x y-D-}$ glucose for reglonal metabolic studies. J. Nucl. Med., 22, 800-803, 1981.

278 Shiue $C Y$ and Wolf $A P$. The synthesis of $1-\left[{ }^{11} C\right]-D-g l u c o s e$ for the measurament of brain glucose metabolism. J. Nucl. Med. 22, 53, 1981. (Abstr.).

270 Winstead $M B$, Podlesny EJ, Winchell HS. Preparation and scintigraphic evaluation of carbon-il-labeled 2-N-phenethylaminoalkanenitriles. Nu'kleamedizin XVII, 277-282, 1978.

290 Winstezc $\mathbb{R B}$, Dischino DD, Winchell HS. Concentration of activity in brain following adninistration of $11 \mathrm{C}$-labeled $\alpha$-p-lodoanilinophenylacetonltrile. Int. J. Appl. Radiat. Isot. 30, 293-295, 1979.

281 Ninstead MB, Nidner PJ, Means IL, et al. Relationship of cherical structure and solvent to in vivo scintigraphic distribution patterns of ${ }^{11} \mathrm{C}$ compounds. 11. ${ }^{11_{C}}$ aminonttriles. J. Nuc1. Med. 16, 1049-1057, 1975. 
282 Winstead MB, Parr S, Lin TH, et al. Synthesis and in vivo distribution

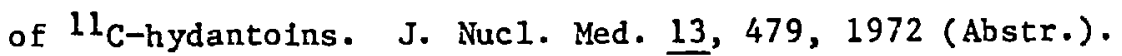

283 Winstead MB, Parr SJ, Rogal MJ, et al. Relationsh1p of molecular structure to in vivo scintigraphic distribution patterns of carbon-11 labeled compounds. 3. $i^{11} \mathrm{C}$ ] hydantolns. J. Med. Chem. 19, 279-286, 1976 .

284 Stavchansky SA, TIlbury RS, McDonald JM, et al. In vivo distribution of carbon-11 phentoin and 1ts major metabolite, and their use in scintigraphic lmagling. J. Nucl. Med. 19, 936-941, 1978.

285 Tilbury RS, Stavchansky S, Ting CT, et al. The preparation and evaluation of diphenylhydantoin $\mathrm{C}-11$ as a tumor scanning agent. J. Nuc1. Med. 16, 575-576, 1975 (Abstr.).

286 Roeda $D$ and Westera $G$. The synthesis of some ${ }^{11} \mathrm{C}$-labelled antlepileptic drugs with potential utility as radiopharmaceuticals: hydantolns and barbiturates. Int. J. Appl. Radiat. Isot. 32, 843-845, 1981.

287 Stavchansky SA, Rostenbauder HB. Synthesis of carbon-14 labeled dighenylhydantino and its major metabolite 5-(p-hydroxypheny1)phengihydantoin (BPPH) in 70 minutes. J. Label Cmpds. Radiopharm. 10, 469-474, 1974.

288 Reliffers S, Vaalburg W, Weigman T, et al. Carbon-11 labeleá methylithium as methyl donating agent. The addition to 17-kezo sterolds. Int. J. Appl. Radiat. Isot. 31, 535-539, 1980.

289 Vaalburg $\mathrm{H}$, Feenstra A, Wlegman $\mathrm{T}$, et al. Carbon-11 labeled moxestrol and $17 \mathrm{a}$-aethylestradiol as receptor binding radiopharmaceuticals. J. Label. Cimpds. Radiopharm. XVIII, 100-101, 1981 (Abstr.).

290 Bergez G, Waziere M, Prenant C, et al. Synthesis of high specific activity ${ }^{1} 1_{C} 17 \alpha$ methyltestosterone. Int. J. Appl. Radiat. Isot. 32, $811-815,1981$.

291 Tang DY, Lipaan A, Meyer G-J, et al. ${ }^{11}$ C-Labeled octanal and benzaidehyde. J. Label. Capds. Radiophara. XVI, 435-440, 1979.

292 Kutzman RS, Meyer GJ, Wolf AP. Biodistribution and excretion of [11 C] benzaldehyde by the rat after two-minute inhalation exposures. Xenobiotica 1.0, 281-238, 1980.

293 Crouze1 C, Mestelan G, Kraus E, et al. Synthesis of a ${ }^{1 l_{C}}$-labeled neuroleptic drig: plmozide. Int. J. AppI. Radiat. Isot. 31, 545-548, 1980.

294 Kloster G, Muller-Platz C. Synthesis, chromatography and tissue distribution of $1-\left[{ }^{11} \mathrm{C}\right]$-hexobarbital. J. Label. Copds. Radiopharm. XVIII, 242-243, 1981 (Abstr.). 
295 Kloster G and Muller-Platz C. Synthesis, chromatography and tissue distribution of $1-\left[{ }^{11} \mathrm{C}\right]$-hexobarbita]. J. Label. Copds. Radiopharm. XVIII, 731-738, 1981.

296 Roeda D, Crouzal C, van der Jagt C, et al. Synthesis of ${ }^{11_{C}}$-urea for medical use. Int. J. Appl. Radiat. Isot. 31, 549-551, 1980.

297 Dischino DD, Wtttmer SL, Ralchle ME, et al. Synthesis and cerebral extraction studies of carbon-11 labeled ethers. J. Label. Compds. Radiopharm. XVIII, 238-239, 1981 (Abstr.).

298 Langstrom $B$ and Sjoberg S. The synthesis of aliphatic and aromatic hydirocarbons containing methyl groups labeled with ${ }^{1 l_{C}}$. J. Label. Copnds and Radiopharm. XVIII, 671-682, 1981.

Speranza M, Ferrieri RA, Wolf AP, et al. Rapld catalytic synthesis of

299 carbon-1l labeled aromatics. J. Label. Cinpnds. Radiophar. XIX, 61-73, 1982.

300 Berger G, Maziere $M$, Prenant $C$, et al. Synthesis of carbon-11-labeled acetone. Int. J. App1. Radlat. Isot. 31, 577-578, 1980.

301 Crawford EJ, Christman D, Atkins $H$, et al. Scintigraphy with posttrou-emitting compounds. I. Carbon-11 labeled thymidine and th:ynddylate. Int. J. Aucl. Med. Biol 5, 61-69, 1978.

$301 a$ Langstroin $B, 5$ jobers $S$, Bergson $G$, at al. [ ${ }^{11}$ C]methyl lodide in the

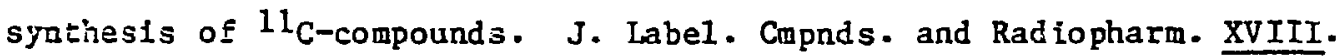
17-19, 1981. (Abstr.).

302 Langstron B, Bergson G. The determination of optimal ylelds and reaction times in syntheses with short-lived radionuclides of high specific: activity. Radiochen. Radioanal. Latt. 43, 47-54, 1980.

303 Wolf AP and Fowler JS. Organic radiopharmaceuticals-recent advances. In Radlapharmaceuticals II, New York, Soclety of Nuclear Medicline, 1979, pp. 73-92.

304 Fowler IS, Arrett CD, Wolf AP, et al.: [ $\left.{ }^{11} \mathrm{C}\right]$ Splroperidol: Synthesis, specific activity determination and biodistribution in mice. J. Nucl. Med., in press, 1982.

305 Canpiell JA, Fina RD, Booth TE et al. Synthesis of C-11 Iodoantipyrine for positron ealssion tomography. J. Nucl. Med. 22, 538-541, 1981.

306 Hoyte RM, Lin SS, Christman DR, et al. Organic radiopharmaceuticals labeled wth short-lived nuclides. III. $18_{\mathrm{F}-l a b e l e d}$ phenylalanines. J. Nucl. Yied. 12, 280-286, 1971.

307 Goulding Riv and Gunasekera SW. Fluorine-18 labeled L-p-Eluorophenylalanine. Int. J. App1. Radiat. Isotopes 26, 561-564, 1975 . 
308 Goulding RW, Clark JC. [18 F]-L-and NL-fluoroaryl amino acids. Present status. J. Label. Cinpds. Radiophar... XVI, 145-147, 1979 (Abstr.).

309 Atkins HL, Christman DR, Fowler JS, et al. Organic radiopharmaceuticals labeled with lsotopes of short half-11fe. V. $18_{\mathrm{F}-1 \text {-labeled } 5 \text { and }}$ 6-fluorotryptophan. J. Nucl. Med. 13, 713-719, 1972.

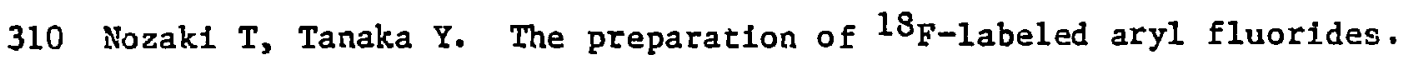
Int. J. App1. Radiat. Isot. 18, 111-119, 1967.

311 Mantescu C, Genucke A, Simionescu L. 18 F-labeling of bioactive molecules using $\mathrm{K}^{18} \mathrm{~F}-\mathrm{CH}_{3} \mathrm{CC}_{2} \mathrm{H}$ solutions as fluorinating reagent.

Radiopharmaceuticals and Labeled Compounds, Vol. 1, IAEA, IAEA-SM-171/94, 1973, Vienna, p. 395-404.

312 Firnau $G$, Nahmlas $C$, Garnett s. Synthesis of 3,4-dihydroxy-5-fluoro-DLphenylalanine and 3,4-dihydroxy-5-[18F] fluoro-DL-phenylalanine. J. Med. Chem. 16, 416-418, 1973.

313 Firnau C, Naimias C, Garrett $s$. The preparation of [ ${ }^{18_{F}}$ ] 5-fluoro-DoPA with reactor produced fluorine-18. Int. J. Appl. Radiat. Isot. 24, 182-184, i $i 973$.

314 Garnett ES, Firnau G. [18F]-5-fluoro-DOPA, as new brain scanning agent. "Radiopharmaceuticals and Labeled Compounds", Vol. 1, IAEA, IAEA-SM$171 / 94,1973$, Vienna, $p \cdot$. 405-410.

315 Firnau G, Cnirakal R, Sood S, et al. Radiofluorination with xenon difłuozide: L-6[18 ${ }^{18_{F}}$ ] fluoro-DOPA. J. Label. Cmpds. Radiopharm. XVIII, 3-4, 1981 (Abstr.).

316 Flrzau G, Chirakal R, Sood S, et al. Aromatic fluorination with xenon difluoride: L-3,4-dihydroxy-6-fluorophenylanine. Can. J. Chem. 58, 1449-1450, 1980 .

317 MacGregor RR, Ansari AN, Atkins HL, et al. 18 potentlal adzenal scanning agent. J. Nucl. Med. 15, 513, 1974 (Abstr.).

318 Ndlokwere CL. Fluorfne-18 labeling of ortho-fluorohippurtc acid by 1sotope exchange reaction. J. Labe1. Cmpds. Radiopharm. XIV, 705-712, 1978 .

319 Kook CS, Reed MF, Digenis GA. Preparation of [ $\left.{ }^{18} \mathrm{~F}\right]$ haloperidol. J. Med. Chea. 18, 533-535, 1975.

320 Digenis CA, Vincent SH, Kook CS, et a1. Tissue distribution studies of [18F] haloperidol, [18F]-B-(4-f]uorobenzoyl)proplonic acid, and [ $\left.{ }^{82} \mathrm{Br}\right]$ broaperidol by external scintigraphy. J. Pharm. Sc1. 70, 985-989, 1981.

321 Tewson TJ, Maeda M, Welch MJ. Preparation of no carrier added $18_{F-a r y l}$ fluorides: scope and conditions for the reaction. J. Label. Cupds. Rad lopharm. XVIII, 21-23, 1981 (Abstr.). 
322 Tewson TJ, Ralchle ME, Welch MJ. Prellminary studies with [18F]haloperidol. A radioligand for in vivo studies of the dopamine receptors. Brain Res. 192, 291-295, 1980.

323 Maeda $M$, Tewson TJ, Welch MJ. Synthesis of high speciflc activity $18_{F}$ spiroperidol for dopamine receptor studies. J. Label. Copds. Radlopharm. XVIII, 102-103, 1981 (Abstr.).

323a Ku $\mathrm{H}$ and Barrio JR. On the synthesis of fluorine-18 labeled spiroperidol: mechanistic studies. J. Nuc1. Med. 22, 13, 1982.

324 Tewson $T J$, Welch MJ. Preparation of fluorine-18 aryl fluorides: plperidyl triazenes as a source of dlazonium lons. J. C. S. Chem. Comn. $1149-1150,1979$.

325 Robblas PJ, Fortman DL, Scholz KL, et al. Synthesis and kinetics of [18F]4'-fluoroantipyrine in normal mice. T. Nucl. Med. 19, 1346-1352, 1978.

326 Adam MJ, Pate $B D$ and Ruth TJ. Cleavage of aryl-tin bonds with elemental fluorlae: rapid synthests of $\left[{ }^{18}\right.$ Flfluorobenzene. J. Chem. Soc. Chem. Cotron. 733, 1981.

327 Cacace $F$ and Wolf AP. Substrate selectivity and orlentation in aromatic substitution by molecular fluorine. J. Amer. Chem. Soc., 100, 3639-3641, 1978.

328 Cacace F, Speranza if, Wolf AP, et al. Labeling of fluorineted aromatics by 1sotopic exchauge with [18F] fluoride, J. Label. Copds. Radlopharm., XVIII, 172i-1730, 1981.

329 Roblason GD. Bloíglcally active 18F-fluoroorganic compounds. Rapid, higi speciflc activity synthesis of $18_{F}$-fluorocarboxylates and derlvatives. in Radiopharmaceuticals and Labeled Compuunds, Vol. 1, IAEA, IAEA-SM-171/94, 1973, Vienna, p. 423-432.

330 Robinson GD. Rapid synthesis of high specific activity, blologically

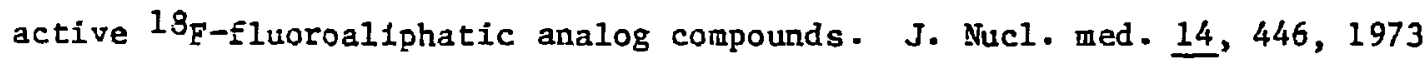
(Abstr.).

331 Karlo 퍼A, Stockl1n G. Fluorine-18 labeling of lower fatty acid esters by heterogeneous exchange on gas chromatographic columns. J. Label. Copds. Radiopharm. XIII, 519-534, 1977.

332 knust EJ, Schuller $M$ and Stocklin G. Synthesis and quality control of long-citain 18F-fatty acids. J. Label. Cupds. Radlopharra. XVII, 353-363, 1980.

333 Kiust EJ, Kupfernagel Ch, Stocklin G. Long-chaln F-18 fatty actds for the study of reglonal metabolism in heart and liver; odd-even effects of metabolism 1n mice. J. Nucl. Med. 20, 1170-1175, 1979. 
334 Berridge MS, Tewson TJ, Welch MJ. The preparation of a no-carrier added fluorine-18 labeled analog of palmitic acid, 7-18 F-palini: ic acid, for radlopharmaceutical use. J. Label. Compds. Radiopharm. XVIII, 240-241, 1981 (abstr.).

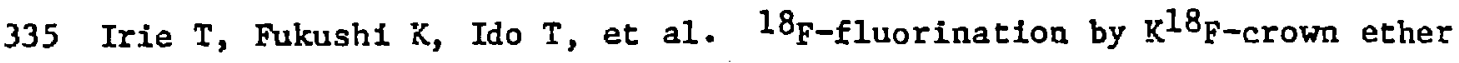
system. J. Labe1. Cmpds. Kad lopharm. XVI, 17-1.8, 1979 (Abstr.).

336 Irie $T$, Fukush $T$, Ido $T$, et al. Fluorine-18 fluorination in a carrler-free state by crown ether. J. Label. Capds. RadLopharm. XVIII, 9-10, 1981 (Abstr.).

337 Spitznagle LA, Marino CA, Eng RR. A study on the use of a crown ether to synthesize a fluorine 18 . labeled sterold. Second International Congress, World Federation of Nislear Mediclne and Blology, p. 71, 1978 (Abstr.).

338 Spitznagel LA, Marino CA. Synthesis of fluorine-18 labeled 21-fluoroprogesterone. Steroids 30, 435-438, 1977.

339 Eng R, Pizn G, Spltznagle L. F-18-21-fluoropregnenolone 3-acetate as an adreral scanning agent. J. Nucl. Med. 16, 526-527, 1975 (Abstr.).

340 Palmer AJ, Widdowson DA. The preparation of $18 \mathrm{~F}$-labeled 4-fluoroestrone and 4-fluoroestradiol. J. Label. Cmpds. Rad1opharm. XVI, 14-16, 1979 (Abstr.)

341 Eakins MN, Palmer AJ, Waters SL. Studies in the rat with

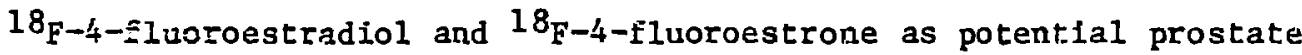
scanntag agents: comparison with ${ }^{125}$ I-todoestradiol and $125 \mathrm{I}-2,4-\mathrm{d}$ i-lodo-oestradiol. Int. J. Appl. Radiat. Isot. 30, 695-700, 1979.

342 Christzan DR, Orhanovik $Z$, Shreeve WW, et al. The synthesis of 6-deoxy-6-18 F-a-D-galactopyranose (XXII). J. Label. Cmpds. Radiopharm. XIII, 555-559, 1977.

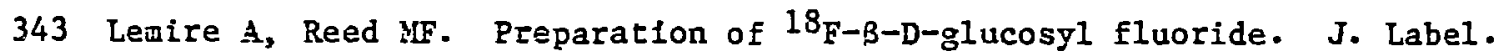
Cmpds. Raciopharm. XV, 105-109, 1978.

344 Ido $T$, Nan $C-N$, Casella V, et al. Labeled 2-deoxy-D-glucose analogs. 18 F-labeled 2-deoxy-2-fluoro-D-glucose, 2-deoxy-2-fluoro-D-mannose, and 14C-2-deoxy-2-fluoro-D-glucose. J. Label. Cmpds. Radlopharm. XIV, $175-183,1978$.

345 Fowler JS, MacGregor RR, Wolf AP, et al. A shlelded synthesis system for production of 2-deoxy-2-[18F]fluoro-D-glucose. J. Nucl. Med., 22, 375-380, 1981.

346 Ido $T$, Wan $C-N$, Fowler JS, et al. Fluorfnation with $F_{2}$. A convenient synthesis of 2-deoxy-2-fluoro D-glucose. J. Org. Chem. 42, 2341-2342, 1977. 
347 Shaughnessy WJ, Gatley SJ, Hickwa RD, et al. Aspects of the production

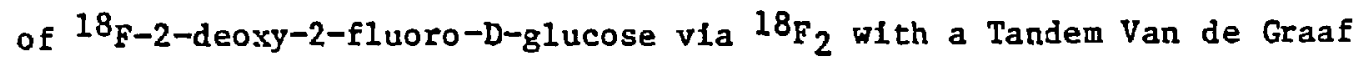
Accelerator. Int. J. Appl. Radlat. Isot. 32, 23-29, 1981.

348 Barrio JR, MacDonald NS, Robinson GD et al. Rerote, semlautomated production of F-18 labeled 2-deoxy-2-fluoro-D-glucose. J. Nucl. Med. 22, 372-375, 1981.

349 Shiue CY, Salvadori PA, Wolf AP, et al. A new improved syathesis of 2-deoxy-2[ ${ }^{18_{F}}$ ] fluoro-D-glucose from $\left[{ }^{18_{F}}\right]$-acetyl hypofluorite, manuscript in preparation.

350 Straatman $M G$, Welch MJ. 18F-DAST as a reagent in the synthesis of an 18 F-sugar. J. Label. Cmpds. Radiopharm. XIII, 210, 1977 (Abstr.).

351 Gatley SJ, Shaugnessy WJ. Synthesis of 18F-3-deoxy-3-fluoro-D-glucose with reactor-produced fluorine-18. Int. J. Appl. Radiat. Isot. 31, 339-341, 1980.

352 Gatley SJ, Shaughnessy WJ. Nucleophilic substitution with fluoride: effects of solvent, temperature, lons, leaving group and water. J. Label. Copds. Radiopharm. XVIII, 24-25, 1981 (Abstr.).

353 Fowler JS, Finn RD, Lambrecht RM, et al. The synthesis of

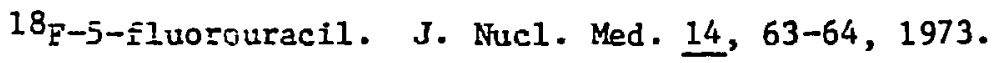

354 Vine EN, Young D, Vine WH, et al. An Improved synthesis of 18 $\mathrm{F}-5$-Fluorouracil. Irt. J. Appl. Radiat. Isot. 30, 401-405, 1979.

355 Abrans DN, Knaus EE, Wiebe LI, et al. 5-18 F-5-fluoro-2'-deoxyuridine: a potential diagnostic agent for tumor metabolism. J. Label. Compds. Radiopharal. XVI, 155-156, 1979 (Abstr.).

356 Abraas DN, Knaus EE, McQuarrie SA, Wiebe LI.

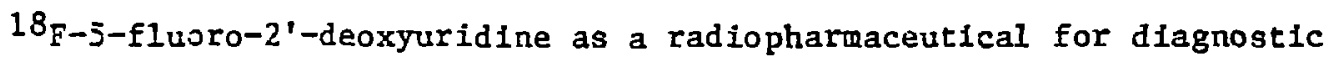
oncology, in The Chemistry of Radiopharmaceuticals, N. D. Helndel, H. D. Burr.5, T. Honda and L. W. Brady, eds., Masson Publishtng Inc., U.S.A., 1978, pp. 205-213.

357 Shiue $C-Y$, Forler JS, MacGregor RR, et a1. The synthesis of $\left[18_{\bar{F}}\right]-\overline{5}-\frac{f}{1}$ luorouridine $(F-18-5-F U R)$ as a probe for measureing RNA synthesis and tumor growth rates in vivo. Rediopharmaceuticals II: Proceedings of the 2nd Int. Symp. on Radiopharmaceuticals, p. 259, 1979 (Abstr.).

358 Ido $\mathrm{T}$, Irle $\mathrm{T}$, Rasida $\mathrm{Y}$. Isotope exchange with $18_{\mathrm{F}}$ on superconjugate system. J. Label. Copds. Radlopharm. XVI, 153-154, 1979 (Abstr.).

359 Abrams DN, Knaus, EE, Mercer JR, et al. 2'-fluoro-2'-deoxyuridine. J. Label. Conds. Radlopharm. XVI, 12-13, 1979.

$3 \in D$ de Kieijn JP, van Zanten $B$, Labeling with reactor-produced fluorine-18. J. Labe1. Crapds. Radiopharm. XIII, 212-213, 1977 (Abstr.). 
361 De Kleijn JP, Seetz JW, Zawierko JF, et al. Labeling with reactor produced $18_{\mathrm{F}}$-III. Polyrer supported $18_{\mathrm{F}}$ as a fluorinating agent. Int. J. Appl. Radiat. Isot. 28, 591-594, 1977.

362 Lemire A, Schroader KJ, Reed MF. The preparation of 18 F-labeled tobacco smoke. J. Label. Cmpds. Radiopharm. XIII, 211, 1977 (Abstr.).

363 Tewson TJ, Welch MJ. Preparation and preliminary blodistribution of "No Carrier Added" fluorine-18 fluoroethanol. J. Nucl. Med. 21, 559-564, 1980.

364 Gatley SJ, Hichwa RD, Shaughnessy WJ et al. $18_{\text {F-Labeled lower }}$ fluoroalkanes; reactor produced gaseous physiologlcal tracers. Int. J. App1. Radiat. Isot. 32, 211-214, 1981.

365 Clark JC, Goulding RW, Palmer AJ. Preparation of $18_{\mathrm{F}}$-labeled fluorocarbons for use in pharmacodynamic studies. In Radiopharmaceuticals and Labeled Compounds, Vol. 1, IAEA, IAEA-SM-171/94, 1973, Vienna, P. 411-421.

366 Shiue $C-Y$, Kutzman R, Wolf AP. The synthesis of [F-18]-4-fluoroantipyrine for the measurement of regional cerebral blood flow. J. Nucl. Med. 21, P53-P69, 1980 (Abstr.).

367 Shiue CY and Folf AP. Synthesis of 4-fluoro-2, 3-diaethyl-1-phenyl-3-pyrazoline-5-one (4-fluoroantipyrine) and 18 F-label. ' analog by direct fluorination of antipyrine with moleculaz fluorine. J. Label. Cmpds. Radiopharm. XVIII, 1059-1066, 1981.

368 Cohen $\mathrm{B}$, Spolter $\mathrm{L}$, MacDonald N, et al. Production of $13 \mathrm{~N}$-labeled amino-acids by enzymatic synthesis. Radiopharmaceuticals and Labeled Corpounds, Vol. 1, IAEA-Si1-171/53, Vienna, 1973, pp. 483-490.

369 Coher MB, Spolter L, Chang CC, et al. Imnobilized enzymes in the production of radiopharmaceutically, pure amino acids labeled with $13 \mathrm{~N}$. J. Hucl. Med. 15, 1192-1195, 1974.

370 Cooper AJL, McDocald J, Gelbard AS, et al. The metabolic fate of

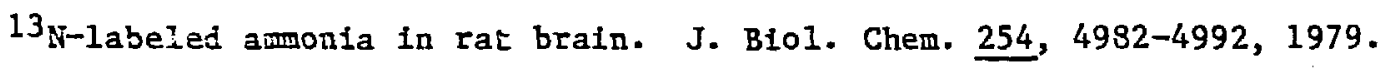

371 Gelbard AS, Benua RS, Reiman RE, et al. Imaging of the human heart after admizistration of L-(N-13) glutamate. J. Nucl. Med. 21, 938-991, 1980 .

372 Lathrop KA, Harper PV, Rich BH, et al. Rapid Incorporation of short-lived cyclotron-produced radionuclides into radiopharmaceuticals. Radiopharmaceuticals and Labeled Compounds, Vol. 1, IAEA-Si1-171/46) International Atouic Energy Agency, Vienna, 1973, p. 471-481.

373 Cooper AJL and Gelbard AS. The use of lomobilized glutamate

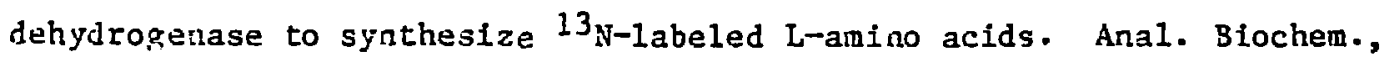
$111,42-48,1981$. 


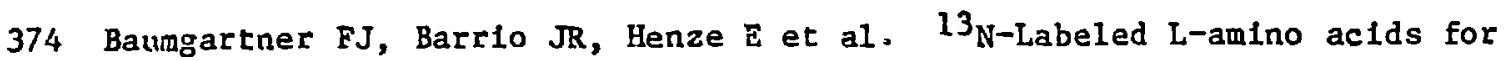
In vivo assessment of local myocardial metabolism. J. Med. Chem. 24, $764-766,1981$.

375 Lembares $N$, Dinwoodie $R$, Glorla $I$, et al. A rapid enzynatic synthesis of 10-min $13_{\mathrm{N}-g l u t a m a t e}$ and its pancreatic localization. J. Nucl. Med. 13, 786,1972 (Abstr.).

376 Coten MB, Spolter L, MacDonald N, et al. Sequential enzymatic synthesis of $13 \mathrm{~N}$-alanine for pancreatic lmaging. Proc. First World Congress of Nuclear Medicine, World Fed. of Nucl. Med. and Biology, 1974, Tokyo, Pp. 907-909.

377 Spolter I, Cohen MB, Chang CC, et al. Semi-automated synthesis and puriflcation of radiopharmaceutically pure $13 \mathrm{~N}-\mathrm{L}$-alanine in a continuous flow system. J. Label. Cmpds. and Radlopharm. XIII, 204-205, 1977 (Abstr.)

378 Geljard AS and Cooper AJ. Synthesis of $\left(13_{\mathrm{N}}\right)$-labeled aronatic L-amino acids by enzyatic transamination of $\left({ }^{13} \mathrm{~N}\right)-\mathrm{L}-\mathrm{glutamic}$ acid. J. Label. Compds. and Radiopharm. XVI, 94, 1979 (Abstr.).

379 Cohez $\mathrm{B}$, Spolter L, MacDonald NS, et al. Enzymatic synthesis of ${ }^{13} \mathrm{~N}$ L-glutazine. J. Nucl. Med. 13, 422, 1972 (Abstr.).

380 Gelbard AS, Clarke LP and Laughlln JS. Enzymatlc synthesis and use of

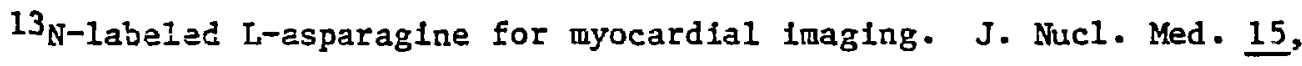
1223-1225, 1974.

381 Majwdar C, Lathrop KA and Harper PV. Synthesis and analysis of $13 \mathrm{y}$-aspazazine for myocardial scanning. J. Label. Cmpds. and Radiopharm. XIII, 206, 1977.

382 Digezis G, MCQuinn RL, Freed B, et al. P'reparation of $13 \mathrm{~N}$-labeled streztozotocla and nitrosocarbaryl. J. Label. Cupds, and Radiopharm. $\underline{X V i}, 95-96,1979$ (Abstr.)

383 Krizek 5 , Harper PV and Mock B. Adapting the old to new needs. 13 If-labeled urea. J. Label. Cmpds. Radiopharm. XIII, 207, 1977 (Abstr.).

384 Elwaleh DR, Hnatowlch DJ and Kulprathipanja S. A novel synthesis of

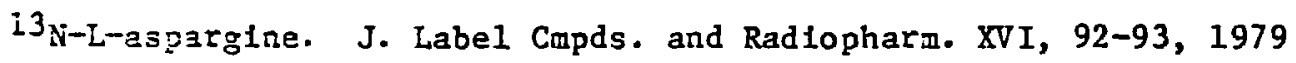
(Abstr.).

385 Lade $R$, Castiglione $M$ and Wolf AP. Synthesis of $13_{W}$-labeled amines. Manuscript in preparation.

386 Finn R.D, Christian DR, Wolf AP. A rapld synthesis of nitrogen-13 labeled amphetamine. J. Label. Conpds. Radiopharm. XVIII, 903-913, 1981.

387 Parker AJ. The effect of solvation or properties of anions in dipolar aprotic solvents. Quarterly Reviews (London) 16, 163-187, 1962. 
388 Friedlander G, Kennedy JW and Miller JM. Nuclear and Radiochemistry, John Wiley and Sons, Inc., New York, 1964, P. 405.

389 Wolf AP. Synthesis of organic compounds labeled with positron emitters and the carrier problem. J. Label. Conds. Radiopharm. XVIII, 1-2, 1981. (Abstr.) (see also Wolf, AP. Reply. J. Nucl. Med. 22, 392-393, 1981).

390 Fry JL and Oh RA. Aldehydes from nitriles. Formation of N-alkylnitrilium ions and their reduction to $\mathrm{N}$-alkyl-aldimines by organosilicon hydrides. J. OrE = Chem. 46, 602-607, 1981.

391 Berger G, iaziere $M_{3}$ Godot JM, et al. Synthesis of radioactive ${ }^{11_{C}}$ molecules for medical research on a micro-scale. a theoretical and practical approach. J. Label. Copds. Radiopharm. XVIII, 1649-1671, 1981.

392 Gelbard AS. Biosynthetic methods for insorporating positron-emitting radionuclides into compuonds of biomedical interest. J. Label. Copds. Radiopharm. XVIII, 333-945, 1981.

393 Meeks JC, Wolk CP, Thomas J, et al. The pathways of assimilation of $13 \mathrm{NH}_{4}+$ by the cyanobacterium, anabaena cylindrica. J. Biol. Chem. 252, $7894-7900,1977$.

394 Mee'ss JC, WoIk CP, Lockau $W$, et al. Pathways of assimilation of [13N] $\mathrm{N}_{2}$ and $13 \mathrm{kH}_{4}{ }^{+}$by cyanobacteria with and without heterocysts. J. Bacteriol. 134, 125-130, 1978.

395 Thomas J, Meeks JC, Wolk CP, et al. Formation of glutamine from $\left[{ }^{13} \mathrm{~N}\right]$ ammonia, [ $\left.{ }^{13} \mathrm{~N}\right]$ dinitrogen, and $\left[{ }^{14} \mathrm{C}\right]$ glutamate by heterocysts isolated from anabaena cylindrica. J. Bacterlol. 129, 1545-1555, 1977.

396 Firestcne MR, Firestone $R B$ and Tiedje JM. Nitric oxide as an interzediate in denitrification: evidence from nitrogen-13 isotope exchange. Blochem. Biophys. Res. Comm. 91, 10-16, 1979.

397 Rrohn RA and Mathis CA. "The use of 1sotopic nitrogen as a blochemical tracer." In Short-Lived Radionuclides in Chemistry and Blology. J.Root and K. Krohn, eds., A.C.S.. Advances in Chemistry Serles Monograph, American Cherical Soclety, Washington, D.C. 1981.

398 Calvin M, et al. Isotopic Carbon, Wiley, New York, 1949, p. 262-271. 399 Walton $z:$. Ion exchange and liquid column chromatography. Anal. Chem. $\underline{52}, 15 \mathrm{R}-27 \mathrm{R}, 1980$.

400 Bibliography Section, Journal of Chromatography 197, B205-B300, 1980.

401 Heftman, E, ed. Chromatography. A Laboratory Handbook of Chromatographic and Electrophoretic Methods, ThIrd Edition, Van Nostrand Reinhold Co., New York, 1975. 
402 Palmer AJ. Liquld chromatography of (18F)-2-deoxy-2-fluoro-D-glucose on cationlc exchange resins. J. Label. Compnd. Radiopharm. XVIII, 264-266, 1981.

403 Goulding RH. The application of HPLC to labeling with short-11ved nuclides. J. Lab. Copnds. Radiopharm. XVI, 207-209, 1979. (Abstr.)

404 Berger G, Mazlere M, Godot JM, et al. HPLC purification of $11_{C}$-labeled rad lopharmaceuticals. Int. J. Appl. Radlat. Isot. 31, 641-643, 1980.

405 Berger $G$ and Knipper R. Remotely controlled frjection of a highly radioactive solution into a liquid chromatograph. J. Radioanal. Chem. $56,251-252,1980$.

406 Still WC, Kahn $M$ and Mitra A. Rapld chromatographlc technique for preparative separations with moderate resolution. J. Org. Chem. 43, 2923-2925, 1978.

407 Targett NM, Kilcoyne JP and Green B. Vacuum 1iquid chromatography: An alternative to common chromatographlc methods. J. Org. Chera. "44, 4952-4954, 1979.

408 Handbook of Chromatography, Vols. I and II, G. Zwelg and J. Sherma, eds. CR.C Press, Cleveland, Ohio, 1972.

408a Prydz S. Sumary of the state of the art in radlochromatography. Anal. Chem. 45, 2317-2326, 1973.

40 Mertel HE, Syrthesis of 1sotoplcally labeled compounds. In Drug Fate and Metabolism, Vo1. 3, E. R. Garrett and J. L. Hirtz, ed., Marce1 Dekker, Inc., New York, 1979, p. 133-191.

410 Evans Ei. Purity and stabllity of radiochemical tracers in autoradiography. In Meth. Cell. B1ol. 10, 291-324, 1975.

411 Evans FA. The validity of radlochemical tracers in pharmacological research. Chem. Ind. (London), 394-400, 1976.

41 la Welch $M T$, Withnel $R$ and Wolf $A P$. An automatic GLPC apparatus for the analysis of organic compounds labeled with short-lived radiolsotopes. Chem. Instrumentation 2, 177-188, 1969.

412 Buchanan $M$ and Eastings $A B$. The use of isotopically marked carbon in the study of internediary metabolism. Physiol. Revs. 26, 120-155, 1946.

413 Raaen VF, Ropp GA, Raaen HP. Carbon-14. McGraw-Hill Series In Advanced Chemistry, New Yo:k, 1968, Chapter 5.

414 Cho ZH, Chan JK, Ericksson L et al. Positron ranges obtained from biomedically important positron-emitting radionuclides. J. Nucl. Med. 16, $1174-1176,1975$.

415 Ache $H J$ and Wolf A?. The effect of radiation on the reactions of recoil carbon-11 in the nitrogen-oxygen system. J. Phys. Chem. 72, 1988-1393, 1968 . 
416 Kabalka GW. Incorporation of carbon-13 and carbon-14 via organoborane technology. Syn. Comm. 10, 93-97, 1980.

417 Kabalka GN. Radionuclide Incorporation vla organoboranes. Aspects of mechanism and organometallic chemistry, editor, J. H. Brewster, Plenum Press, New York, 1978, pp. 199-205.

418 Kabalka WW, Gooch EE, Collins CJ, Raven VF. New method for isotopic labelling of organic compounds involving organoboranes. J. Chem. Soc. Chc.4. Comm. 607, 1979.

419 Nash T. The colorimetric estimation of formaldehyde by means of the Hantzsch reaction. Blochem. J. 55, 416-421, 1953.

420 Epstein J. Estimation of microquantities of cyanide. Ana1. Chem. 19, 272-274, 1947.

421 Canterford DR. Simultaneous determination of cyanide and sulfide with direct current polarography. Anal. Chem. 47, 88-92, 1975.

422 Enna S.I. Radioreceptor assay techniques for neurotransmitters and drugs. In Neurotransmitter Receptor Binding, editors, H. I. Yamamura, S. J. Enna, Y. J. Kuhar, New York, Raven Press, 1978, pp. 127-139.

423 Halparn $A$ and Stocklin $G$. Chemical and biological consequences of B-decay. Parts 1 and 2, Rad. and Envizon. Biophysics 14, 167-183 and $257-274,1977$.

424 Kassis AI, Adelstein SJ, Fowler JS, et al. Uptake and radiotoxicity of F-18-2-F̂luoro-2-deoxyglucose in mammallan cells. J. Nucl. Med. 22, 45, 1981.

425 Pauling I. The nature of the chemical bond. Cornell Univ. Press, Ithace, New York, ed. 3, 1960, p. 82.

426 Goldzan $P$. The carbon-fluorine bond in compounds of blologlcal intezest. Sclence 164, 1123-1130, 1969.

427 Filler, R., editor. Blochemlstry Involving carbon-fluorine bonds. ACs Syuposiliz Series 28, American Chemical Society, Washington, D. C., 1976.

428 Carbon-Fluorine Cogpounds. Chemistry, Bfochemistry and Blologica. Activities. A Ciba Foundation Symposium, Assoclated Scientiflc Publishers, Amsterdam, 1972.

429 kollouitsch J. Novel methods for selective fluorination of organic compotids: design and synthesis of fluorlnated antimetabolites. Israel J. Cher. $17,53-59,1978$.

430 Schlosser $M$. Introduction of fluorine into organic molecules: Why and how. Tetrahedron 34, 3-17, 1973.

431 Robirson GD. Prospects for ${ }^{18}$ F Radiopharwaceuticals. Radiopharmaceuticals, G. Subramanian, B. Rhodes, J. Cooper, V. Sodd, Eds., Soc. Nuc1. Med., Inc., New York, 1975, p. 141-148. 
432 Palmer AJ. Rac̈jopharmaceuticals containing fluorine-18. Proc. Anal. Div. Chem. Soc. 15, 289-293, 1978.

433 deKleljn JP. Fluorlne-18 labeled compounds. Vrije Universiteit te amsterdam, 1978, INIS-mf-4392, pp- 9-85.

433a Roe A. Preparation of aromatic fluorine compounds from diazonium fluoborates. The Schiemann reaction. Organic Reactions, Vol. 5, Roger Adams, ed., Wiley, New York, 1949, p. 193-228.

434 Wallach 0 . Uber das verhalten einiger diazo und diazoamidoverbindungen. Annalen 235, 233-271, 1886.

435 Rosenfeld MN and Widdowson DA. New pathways to aromatic fluorination. J. Label. Conpds, Radio hiarm. XVIII, 20, 1981. (Abstr.)

436 Rosenfeld MN and Widdowson DA. A mild and efficient method of aromatic fluorfnation. J. Chem. Soc. Chem. Comm., 914-916, 1979.

437 Ng JS, Retzenellenbogen JA, Kilborun MR. Aromatic fluorinations sultable for fluorine-18 labeling of estrogens. J. Org. Chem. 46, 2520-2528, 1981.

438 de Oliveria Baptista MJV and Widdowson DA. The relative nucleophillcities of fluoride and aryloxy lons towards acyl and nitroaryl groups. J. Chem. Soc., Perkin I, 295-298, 1978.

439 Sheppard wA and Sharts CM. Organic fluorine chemistry, W. A. Benjamin Inc., Nier Fork, 1969.

440 Zweig A, Fischer RG and Lancaster JE. New method for selective monoziluozination of aromatics using silver difluoride. J. Org - Chem. 45, $3597-3603,1980$.

441 Shaw $X$, Jyman $H H$ and Filler $R$. Reaction of xenon difluoride wth berzene. J. Am. Chem. Soc. 91, 1563-1565, 1969.

442 Filler $\mathrm{R}$. Reactions of organic compounds with xenon fluorides. Israel J. Chen. 17, 71-79, 1978.

443 Stevber $S$ and Zupan $M$. Caesiun fluoroxysulphate as a mild fluorinating agent For the fluorination of alkoxy substituted benzene and naphthalene derivatives. J. Chem. Soc. Chem. Comm., 148, 1981.

444 Eesse RG. Application of fluoroxy compounds to organic synthesis: electrophilic fluorination of unsaturated molecules. Israel Journal of Chezistry 17, 60-70, 1978.

445 Patrick IB, Schield IA and Kirchner DG. Synthesis of fluoroaromatic antines. J. Org. Chem. 39, 1758-1761, 1974.

446 Mulvey DM, Delarco AM and Neinstock LM. A novel synthesis of Fluoroaromatics. Tetrahedron Lett. 1419-1420, 1978.

447 Taylor EC, Bighan EC, Johnson DK, et al. Thallium in organic synthesis. 45. Synthesis of aromatic fluorides. J. Org. Chem. 42, 362-363, 1977. 
448 Sharts CM and Sheppard WA. Modern methods to prepare monofluoroaliphatic compounds. Organic Reactions, Vol. 21, W. G. Dauben, ed., Wiley, New York, 1974, p. 125-406.

449 Hudlicky M. Chemistry of Organic Fluorine Compounds, 2nd edition. Halsted Press (a division of John Wiley and Sons) New York, 1976.

450 Clark JH. Fluoride Ion as a base in organic synthesis. Chem. Rev. 80, 429-452, 1980.

451 Kimerle FM, Archambault $A$ and Dube G. Construction of a novel generator for use in HF adsorption studies. Can. J. Chern. 56, 2034-2038, 1978.

452 Gerstenberger MRC and Haas A. Methods of fluorination in organic chemistry. Angew. Chem. Int. Ed. Engi. 20: 647-667, 1981.

453 Chambers RD. Fluorine in Organic Synthesis, John Wiley and Sons, New York, 1973.

454 Kitazue $T$ and Ishikawa $N$. Fluorination of activated halogens wil.h KF in polyethylene slycol-acetonitrile system. Tetrahedron Letc. 282-284, 1978.

455 Colonze S, Re A, Gelbard $G$, et al. Anionic activation in polymer supported reactions. Part 2. Stereochemical studies on the introduction of fluorine at chiral centres and in blologically significant molecules. J. Chen. Soc., Perkin I, 2248-2252, 1979.

456 Katriczkg AR. Converston of primary amino groups into other functionality mediated by pyrylium cations. Tetrahedron 36, 679-699, 1980.

457 Middleton WJ. New fluorinating reagents. Dialkylaminosulfur fluorides. J. Org. Chen.n. 40, 574-573, 1975.

458 Kollonitsch J, Merburg $S$ and Perkins LM. Fluorodesulfurization. A new reaction for the formation of carbon-fluorlne bonds. J. Org. Chem. 41, $3107-3111,1976$.

459 Ranganathan R. Modification of the 2'-position of purine nucleosides: synthesis of $2^{\prime}-\alpha$-substituted-2'-deoxyadenosine analogs. Tetrahedron Lett. 1291-1294, 1977.

460 Dshita $I_{3}$ Morlsaki M and Trekawa $N$. Synthesis of 2-3-1 Iuoro-Ia-hydroxyvitamin $\mathrm{D}_{3}$. Tetrahedron Lett. 21, 1755-1756, 1980.

461 Pacak J, Podesva $J$ and Cerny M. Synthesis with anhydro sugars. XI. prepazation of 2-deoxy-2-fluoro-D-glucose and 2,4-dideoxy-2,4-difluoro-D-glucose. Coll. Czech. Chem. Comn. 37, 2589-2599, 1972 . 
462 Olah GA, Nelch JT, Vankar YD, et al. Synthetic methods and reactions. 63. Pyridinium poly (hydrogen fluoride) ( $30 \%$ pyridine - $70 \%$ hydrogen fluoride): A conventent reagent for organic fluorination reactions. J. Org. Chem. 44, 3872-3881, 1979.

463 Wade $T N$ and kheribet $R$. New convenient synthesis of 3,8-difluoro amines and $\beta, \beta-d 1 f l u o r o-a-a m i n o$ acid alkyl esters by the addition of hydrogen fluoride to 1-azirenes. J. Org. Cher. $\underline{45}, 5333-5335,1980$.

464 Wade TN. Preparation of fluoro anines by the reaction of aziridines with hydrogen fluoride in pyridine solution. J. Org. Cher. $\underline{45}, 5329-5333$, 1980.

465 Alker D, Barton DHR, Hesse RH, et al. Selective fluorination at tertiary centres in steroids and adamantanoids using fluoroxytrifluoromethane and using molecular fluorine. Nouveau J. de Chemle. 4, 239-254, 1980.

466 Matheson Gas Date Book. Rutherford, NJ, Matheson Co., Inc., 1971, pp. 21i-215.

467 Chemical Hazards Bulletin, No. C-61, Fluorlne, New York, American Insurance Association.

468 Rozen $S$, Lerman $D$, and Kol M. Acetyl hypofluorite, the first member of a ner fanily of organic compounds. J. Chern. Soc. Chen. Comm. 443-444, 1981.

469 Rozen $S$ and Lernan 0 . Synthesis and chemistry of trifluoroacetyl hypofluorite with elemental fluorine. A novel method for synthesis of a-fluorohydrins. J. Org. Chem. 45, 672-678, 1980.

470 Rozen S and Menachem $Y$. New approach to the synthesis of e-fiuoro-oxc-sterolds. J. Chem Soc. Chem. Comn. 479-480, 1979.

471 Rozed $S$ and Lerman 0 . A new approach to the syntheses and chemistry of fluoroxy compounds. J. Amer. Chem. Soc. 101, 2782-2784, 1979.

472 Zajc $B$ and Zupan $M$. Room temperature fluorlnation of 1,3-diketones and enol acetates with xenon difluorides. J. Chem. Soc. Chem. Comm. 759-760, 1980 .

473 Leroy J and Wakselman C. Electrophilic fluorination of diazoketones. J. Cnea. Soc. Perkin I, 1224-1227, 1978.

474 Patrick TB, Scheibel JJ, Cantrell GL. Geminal fluorination of diazo compounds. J. Org. Chem. 46, 3917-3918, i981.

475 Middleton WJ and Bingham EM. a-fluorination of carbonyl compounds with $\mathrm{CF}_{3} \mathrm{OE}$. J. Amer. Cheri. Soc. 102, 4845-4846, 1980.

475 Barton DHR, Hesse 2H, Markwell RE, et al. Fluorination at saturated carbor. 1. Direct substitution of adamantanes. J. Am. Chem. Soc. 98 , 3034-3035, 1976. 
477 Barton DHR, Hesse RH, Markwell RE, et al. Fluorination at saturated carbon. 2. Direct fluorination of steroids. J. Am. Chem. Soc. 98, $3036-3037,1976$.

478 Rozen S, Gal C, Faust Y. Remote and selectlic electrophilic fluorinations at the carbon-hydrogen single bond. J. Amer. Cher. Soc. $102,6860-6851,1980$.

$479 \mathrm{Gal} C$, Ben-Shoshan $G$ and Rozen S. Selective fluorination on tertiary carbon-hydrogen single bonds in the aliphatic series. Tetrahedron Lett. 21, 5067-5070, 1980.

480 Korytnyk W and Valentekovic-Horvat S. Reactions of glycals with xenon fluoride: an improved synthesis of 2-deoxy-2-fluorosaccharides.

Tetrahedron Lett. 21, 1493-1496, 1980.

481 Rozen $S$ and Brand $M$. Electrophilic attack of elemental fluorine on organic halogens. Synthesis of fluoroadamantanes. J. Org. Chem. 46, 733-736, 1981 .

482 Leraan 0, Tor $\mathrm{Y}$, Rozen S. Acetyl hypofluorlte as a taming carrier of elemental fluorine for novel electrophilic fluorination of activated aroaatic rings. J. Org. Chem. 46, 4629-4631, 1981.

483 Grakauskas V. Direct liquid-phase fluorination of aromatic compounds. J. Org. Chem. 35, 723-728, 1970.

484 Ruth IJ and Wolf AP. Absolute cross sections for the production of $18 \mathrm{~F}$ via the ${ }^{18} O(p, \pi)^{18} F$ reaction. Radioch1m. Acta 26, 21-24, 1979.

485 Berl S, Takagaki G, Clarke G, et al. Metabolic compartments in vivo. Amrozic and glutamic acid metabolism in brain and liver. J. Biol. Chem. $237,2562-2569,1962$.

486 Aten Jr AHN and Kapteyn JC. The chenical state of radio-nitrogen atoms produced in water. Radiochem. Radioanal. Lett. 32, 83-86, 1978.

487 Tilbury RS and Dahl JR. ${ }^{13} \mathrm{~N}$ species formed by proton irradiation of water. Radiat. Res. 79, 22-33, 1979.

488 Gelbard AS, Freed BR, Cooper AJL, et al. "13N-labeled L-amino acids: Enzywatic syatheses and metabolic studies" in Short-Lived Radionuclides in Chemsitry and Biology. J. Root and K. Krohi, eds., A.C.S. Advances in Chenistry Series Monograph, American Chemical Society, Washington, D.C., 1981 .

489 Kabalka GH, Sastre KAR, McCollum GN, et al. Synthesis of nitrogen-15-labelled primary amines via organoborane reactions. J. Cher. Soc. Chere. Corm. 62, 1982.

490 Knoll GF. Radiation Detection and Measurement, John Wiley and Sons, New York, 1979. 
491 Christman DR. Choosing a method for counting soft betas. Nucleonics 19, 51-55, 1964.

492 Christman DR and Paul CM. Gas proportional counting of carbon-14 and tritium, and the dry combustion of organic compounds. Anal. Chem. 32 , $131-132,1960$.

493 Fowler JS, Karlscrom $K_{2}$ " Yohler $C$, et al. A hot cell for the synthesis of labeled organic compounds. Proceedings of the 27 th Conference on Remote Systems Technology, Pp. 310-313, 1979.

494 Barrio JR, Robinson GD, Najofi A. Remote systems for chemistry using large anounts of cyclotron produced radionuclides. J. Nucl. Med. 21, P92, 1980. (Abstr.)

495 Maziere $M$, Berger $G$, Prenant $C$, et al. 11C-radiopharmaceuticals: problems of thelr routine use in man. J. Label. Copds. Radiopharm. XVIII, 258, 1981. (Abstr.)

496 Wieland $3 \%$, Washburn LC, Turtle RR, et al. Development of cyclotron targetry and remote radiochenical techniques for the continuous large-scale production of ${ }^{11_{C}} \mathrm{C}$-labeled amino acids. J. Label. Canpds. Radiophard. XIII, 202, 1977. (Abstr.) 
SUBJECT INDEX

Accelerators - 7

Acetyl Hypo [ ${ }^{18}$ F] fluorite - 9,58,60

Aromatic fluorination reactions - 49

nucleophilic aromatic substitution - 51

Schiemann reaction - 49,60

triazine decomposition - 49

Automation - 41,42,70

Biosynthesis - 31

Blood-Brain-Barrier - 4

Braln uptake - 4

Carbon-11 - 38

carrfer problem - 39,43,46

compounds

alcohols - 14

amines and derivatives - 13,26,27

amino actds - 11,44,33,43,45

carboxylic acids - 11,33,42

hydantoins - 15

N-methyl amines - 12,72

N-methyl quaternary ammonium salts - 12

aiscellaneous compounds - 15

nitriles - 14,44

steroids - 15

sugars - 14,26,32

isotope effects - 38

precursors - 9

carbon dioxide - 40

carbon moroxide - 46

formaldehyde $-41,28,46$.

hydrogen cyanide $41,28,43,46$

merhyl iodide - 41

Carbon-14 - 2,39,47,82

Carbon-fluorine bond - 48

Carbonylation $\left({ }^{11_{C O}}\right)-46$

Carboxylation $\left({ }^{11} \mathrm{CO}_{2}\right)-42$

Chromatography

flash chromatography - 36

gas Iiquid chromatography - 37 
Chromatography (continued)

high pressure liquid chromatography - 36,70

Ion exckange chromatography - 35

medium pressure liquid chromatography - 36

thin layer chromatography - 37

radioactivity detectors - 37

Cyclotrons -7

2-Deoxy-2-fluoro-D-glucose-synthesis - 5,57,58,76

2-Deoxy-D-glucose-1-11 C - 25

Design of radiotracers - 3

Electrophilic fluorination - 56

reactions - examples - 57,58,59

reagents - $56,57,58$

Enzymatic sfothesis - 31,62

Enzyme Inhibitars - 4

Fluoride salts - 52

displacement reactions - examples - 50,52,53,54,55

nucleophilicity - 52

preparation of anhydrous - 52,53

Fluorine-18

carbon-fluorine bond - 48

compounds - 17

argl fluorides - 17,50

carboxylic actds - 18,54

miscellaneous compounds - 20,54,57

pyrimldines - 20,57

scerolds - 19,53

sugars - $19,53,57,58$

precursors - 9,49,60

ace:yl hypofluorite $-9,58,60$

fluorine (elemental) - 9,56,60

hydrogen fluoride $-9,50$

Fluorine (elemental) - 56

Grignard reaction

Imipramine-11 $\mathrm{C}-72$

Imriobilized enzymes - 33,63

Ion chamber - 65

callbration - 65

Isotope effects - 38

Lipophilicity - 4

Liposomes - 4 


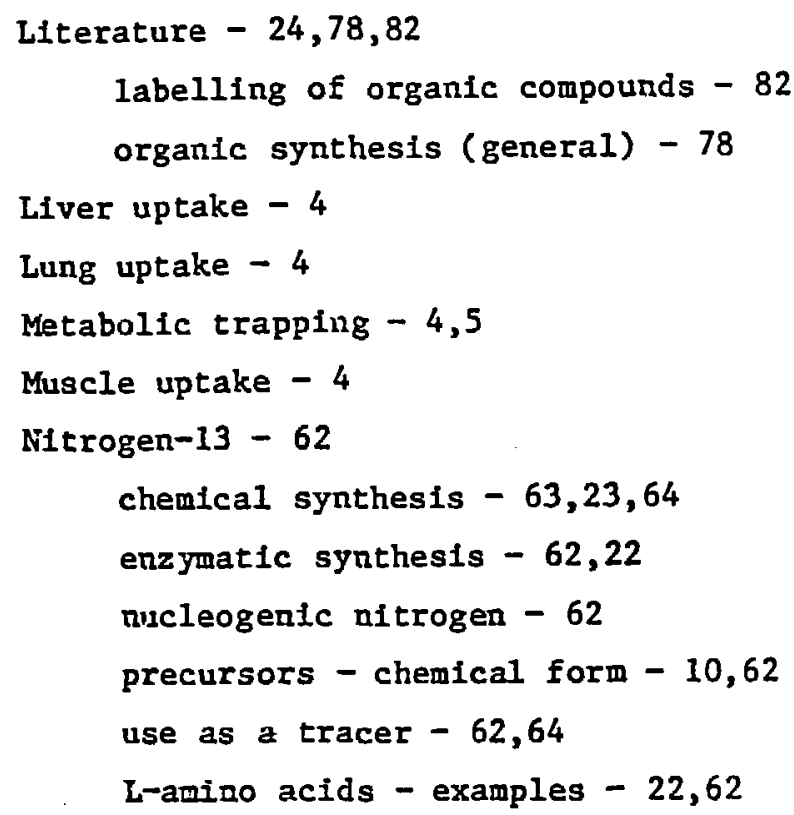

Non-synthetic labeling - 24

Nucleophilic Eluorination - 50

aryl fluoride synthesis - 50,51

aliphatic Iluoride synthesis - 52

Palmitic acid-11 $\mathrm{C}-74$

Partition coefficients - 4

pH (Intracelluiar) - 4

Plasma proteia binding - 4

Protective groups - 26,28,80

Purification methods - 34

flash cinzomatography - 36

gas Ifquid chromatography - 37

high pressure liquid chromatography - 36

Ion exchange chromatography - 35

mediun pressure 11quid chromatography - 36

thin lager chromatography - 37

Posttron emission transaxial tomograpy - 1

Positron eaitters - 1

blological consequences of decay -46

decay characteristics - 2

range -2

specific activity - 2

Precursors - 7

carbon-11 - 9,39

fluorine-18 - 9

nftrogen-13 - 10 


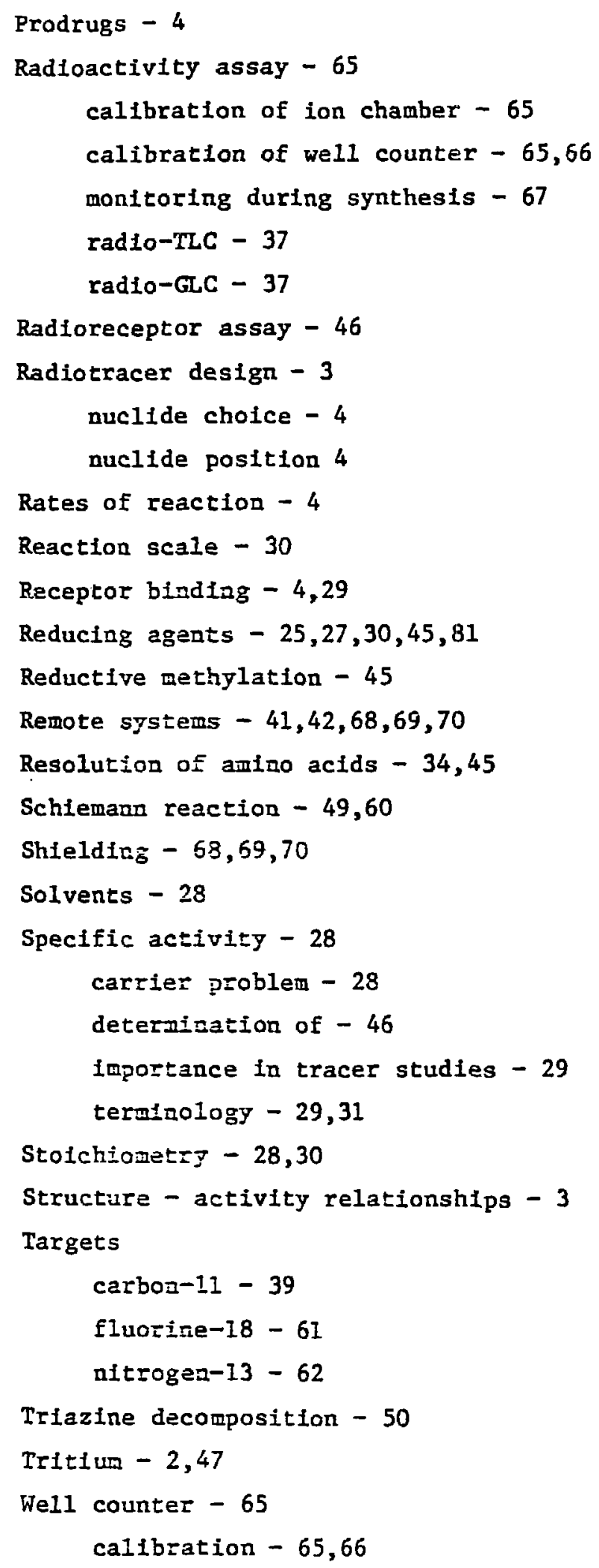

